\title{
Opleidingsclassificatie naar Niveau en Richting 2019: Achtergronddocumentatie
}

Citation for published version (APA):

Bakens, J., Dijksman, S., \& Fouarge, D. (2019). Opleidingsclassificatie naar Niveau en Richting 2019: Achtergronddocumentatie. ROA. ROA Technical Reports No. 001 https://doi.org/10.26481/umarot.2019001

Document status and date:

Published: 21/05/2019

DOI:

10.26481/umarot.2019001

Document Version:

Publisher's PDF, also known as Version of record

\section{Please check the document version of this publication:}

- A submitted manuscript is the version of the article upon submission and before peer-review. There can be important differences between the submitted version and the official published version of record.

People interested in the research are advised to contact the author for the final version of the publication, or visit the DOI to the publisher's website.

- The final author version and the galley proof are versions of the publication after peer review.

- The final published version features the final layout of the paper including the volume, issue and page numbers.

Link to publication

\footnotetext{
General rights rights.

- You may freely distribute the URL identifying the publication in the public portal. please follow below link for the End User Agreement:

www.umlib.nl/taverne-license

Take down policy

If you believe that this document breaches copyright please contact us at:

repository@maastrichtuniversity.nl

providing details and we will investigate your claim.
}

Copyright and moral rights for the publications made accessible in the public portal are retained by the authors and/or other copyright owners and it is a condition of accessing publications that users recognise and abide by the legal requirements associated with these

- Users may download and print one copy of any publication from the public portal for the purpose of private study or research.

- You may not further distribute the material or use it for any profit-making activity or commercial gain

If the publication is distributed under the terms of Article $25 \mathrm{fa}$ of the Dutch Copyright Act, indicated by the "Taverne" license above, 


\section{Maastricht University $\mathrm{ROA}$}

\section{Opleidingsclassificatie naar Niveau en Richting 2019: Achtergronddocumentatie}

Jessie Bakens

Sander Dijksman

Didier Fouarge

\section{ROA Technical Report}

ROA-TR-2019/1

Researchcentrum voor Onderwijs en Arbeidsmarkt | ROA Research Centre for Education and the Labour Market / ROA 


\title{
Opleidingsclassificatie naar Niveau en Richting 2019: Achtergronddocumentatie
}

\author{
Jessie Bakens \\ Sander Dijksman \\ Didier Fouarge
}

ROA-TR-2019/1

April 2019

Research Centre for Education and the Labour Market Maastricht University

P.O. Box 616, 6200 MD Maastricht, The Netherlands

$\mathrm{T}+31433883647 \mathrm{~F}+31433884914$

secretary-roa-sbe@maastrichtuniversity.nl www.roa.nl 


\section{Inhoud}

1 Inleiding 3

Databronnen voor opleidingsniveau en -richting 3

Uitgangspunten nieuwe classificatie 3

Opleidingsindeling 4

2 Mbo 5

2.1 Mbo 3 en 4

Stap 1: classificatie op basis van gediplomeerden in

administratieve data 5

Stap 2: toepasbaarheid classificatie beroepsbevolking 6

Stap 3: aggregeren van classificatie naar voldoende observaties voor alle niveaus van de indeling

Stap 4: stroomlijnen toekenning ISCEDF2013-codes over verschillende niveaus en richtingen

Stap 5: controle naamgeving van de classificatie naar onderliggende opleidingen (voornamelijk op het niveau van de ONRtype en ONRsubsector)

$2.2 \mathrm{Mbo} 2$

6

3 BAMA 8

3.1 Bachelor (hbo-, wo-bachelor en ad-opleidingen) en Master (hbo, womaster, en doctor)

Stap 1: ISCEDF2013 broad- en narrow field indeling voor gediplomeerden in administratieve data

Stap 2: toepasbaarheid classificatie beroepsbevolking

Stap 3: aggregeren van classificatie naar voldoende observaties voor alle niveaus van de indeling

Stap 4: stroomlijnen toekenning ISCEDF2013-codes over verschillende niveaus en richtingen

Stap 5: controle naamlabels van de classificatie naar onderliggende opleidingen (voornamelijk op het niveau van de ONR2019type en ONR2019subsector)

4 Opleidingsclassificatie naar Niveau en Richting 2019 (ONR2019): Tabellen 


\section{Ten Geleide}

Deze opleidingsclassificatie (ONR2019) is tot stand gekomen binnen het Project Onderwijs Arbeidsmarkt ${ }^{1}$, mede dankzij financiering van NRO (dossiernummer 40517-900), UWV, S-BB, en Randstad. De ONR2019 zal vanaf 2019 de oude opleidingsclassificatie (2015) vervangen binnen het Project Onderwijs Arbeidsmarkt. De eerste toepassing van de ONR2019 is te vinden in de arbeidsmarktprognoses naar opleiding en beroep tot 2024 en het AIS 2019 die in december 2019 zullen verschijnen. Dit Technisch rapport geeft de opzet en indeling van de opleidingsclassificatie weer.

ROA is Sue Westerman (CBS), Lisan van den Beukel (UWV Werkbedrijf), Francis van der Mooren (CBS), en Michel van Smoorenburg (UWV Werkbedrijf) zeer erkentelijk voor het leveren van uitgebreide aanbevelingen en feedback op de opzet en indeling van de opleidingsclassificatie.

${ }^{1}$ http://roa.sbe.maastrichtuniversity.nl/?portfolio=poa-project-onderwijs-arbeidsmarkt2 


\section{$1 \quad$ Inleiding}

Binnen het 'Project Onderwijs-Arbeidsmarkt' (POA) heeft ROA een nieuwe Opleidingsclassificatie naar Niveau en Richting (ONR2019) ontwikkeld die met ingang van 2019 gebruikt zal worden. ${ }^{2}$ De aanleiding hiervoor is tweeledig. Ten eerste is de codering van onderwijsrichting in de Enquête Beroepsbevolking (EBB) van het Centraal Bureau voor de Statistiek (CBS), een van de belangrijkste databronnen voor POA veranderd van ISCEDF1997 naar ISCEDF2013 (de International Standard Classification of Education; in de EBB worden de opleidingen niet gecodeerd naar CREBO of $\mathrm{CROHO}$ ). Hierdoor kan de huidige classificatie van opleidingen ${ }^{3}$ niet meer worden afgeleid op basis van de data. Ten tweede hebben stakeholders behoefte aan een uitsplitsing tussen de niveaus 2 en 3 van het mbo, hetgeen niet mogelijk was met de huidige indeling. Op verzoek van ROA heeft CBS een nieuwe variabele afgeleid op basis van EBB-informatie waardoor het maken van een onderscheid tussen mboniveau 2 en 3 nu wel mogelijk is.

Bij het opstellen van de ONR2019 is primair rekening gehouden met de bruikbaarheid van de opleidingsclassificatie voor POA. Omdat ook andere partijen de opleidingsclassificatie gebruiken, is in overleg met het CBS toegewerkt naar een classificatie die ook breder dan alleen voor POA toepasbaar is en ook door het CBS toegevoegd kan worden aan de bestaande lijst van afleidingen van opleidingsclassificaties. Bij het tot stand komen van deze opleidingsindeling is veelvuldig overlegd met leden van de POA-begeleidingscommissie en CBS.

\section{Databronnen voor opleidingsniveau en -richting}

Het CBS heeft verschillende databronnen waarin het opleidingsniveau van de Nederlandse bevolking wordt gemeten. De registerdata van DUO, gebaseerd op inschrijvingen van studenten aan onderwijsinstellingen, geeft in detail voor de gehele afgestudeerde studentenpopulatie aan wat het behaalde opleidingsniveau en -richting is. Daartegenover staat de steekproef van de EBB, waarin een representatief deel van de Nederlandse beroepsbevolking wordt gevraagd naar haar hoogst genoten opleiding, zowel naar het niveau als naar de richting van de opleiding. De EBB is daarnaast de enige databron waarin naast de opleiding, ook gevraagd wordt naar het beroep van werkenden, en de sector waarin men werkzaam is. De combinatie van opleiding, beroep, en sector is nodig voor het doorrekenen van ROA arbeidsmarktprognoses. ${ }^{4}$

Er zijn dus verschillende bronbestanden waarin opleidingen van de beroepsbevolking geregistreerd worden, maar omdat de registratie op een andere manier wordt uitgevoerd, kunnen er verschillen tussen beide bronnen ontstaan. Deze verschillen hebben betrekking op de aard van registratie; administratieve data omvat bijvoorbeeld alleen afgestudeerden aan Nederlandse, reguliere, onderwijsinstellingen, terwijl de hoogste genoten opleiding in de EBB ook een bedrijfsopleiding kan zijn, of een buitenlandse opleiding. Ook de beschikbare periode van de gegevens verschillen. Zo zijn de administratieve data sinds een relatief korte periode beschikbaar, zodat mensen die 30 jaar geleden zijn afgestudeerd niet in de data voorkomen. Anderzijds worden in de EBB de richting en het niveau van de opleiding apart bevraagd waardoor deze kunnen afwijken van de bestaande, bekende opleidingen.

\section{Uitgangspunten nieuwe classificatie}

Aangezien POA gebruik maakt van zowel de EBB gegevens voor de combinatie van beroep, opleiding en sector, als DUO-data voor de onderwijsmatrix van afgestudeerden voor de instroom op de arbeidsmarkt, moet een nieuwe opleidingsclassificatie in zowel de EBB als de administratieve data toepasbaar zijn. Tevens moet de opleidingsclassificatie herkenbaar zijn voor gebruikers van de arbeidsmarktprognoses.

\footnotetext{
2 Dit rapport is tot stand gekomen als onderdeel van het Project Onderwijs-Arbeidsmarkt (POA), mede dankzij de financiering van NRO (dossiernummer 405-17-900), UWV, S-BB en Randstad. Zie: http://roa.sbe.maastrichtuniversity.nl/?portfolio=poa-project-onderwijs-arbeidsmarkt$\frac{2}{3}$

${ }^{\frac{2}{3}} \mathrm{ROA}$ (2016). ROA opleidingsindeling 2015. Maastricht: ROA-TR-2016/3.

${ }^{4}$ Zie gebruikte methodiek in: Bakens, J., Bijlsma, I., Cörvers, F., Dijksman, S., Fouarge, D., \& Poulissen, D. (2018). Methodiek arbeidsmarktprognoses en -indicatoren 2017-2022. Maastricht: ROA-TR-2018/4.
} 
De toepassing van de ONR2019 voor POA betekent daarnaast dat de classificatie niet alleen alle bestaande opleidingen omvat, maar er voornamelijk op gericht is dat er voor de verschillende niveaus en richtingen binnen de opleidingsclassificatie (statistisch) voldoende werkenden op de arbeidsmarkt zijn en er voldoende gediplomeerden de arbeidsmarkt toetreden zodat de prognoses gebaseerd op deze werkenden en de instroom betrouwbaar zijn.

Vanuit de financiers van POA en de stakeholders in het onderwijsveld bestaat daarnaast de vraag om meer detail en een goede aansluiting van de classificatie bij de praktijk van het onderwijs. Hierbij is voor de classificatie op mbo-niveau als uitgangspunt de domeinstructuur genomen. Echter, bij de naamgeving van de opleidingen en het aggregeren van opleidingstypes naar opleidingscategorieën is er van de domeinstructuur afgeweken. Dit is gedaan om de toepasbaarheid van de indeling te garanderen als er alleen ISCEDF2013codes (en geen CREBO-codes) beschikbaar zijn in de data (zoals in de EBB), voor domeinen met een klein aantal leerlingen, of om de consistentie tussen de verschillende mbo-niveaus te behouden. Het resultaat is dat de ONR2019 dus niet hetzelfde is als de mbo-domeinindeling, maar dat de domeinindeling voornamelijk bij grote opleidingen wel herkenbaar is.

Voor het hoger onderwijs is er voor gekozen om de bachelor-masterstructuur (bama) aan te houden, waarbij de structuur van de samenhang van de ISCEDF2013 codering op detailniveau als uitgangspunt genomen is. Onze analyses van de samenhang van bachelor- en masteropleidingen in het hbo en wo op basis van de beroepenstructuur laten zien dat de bama-structuur voor de grootste opleidingen in de praktijk een logische keuze is. De bama-structuur is echter niet voor alle opleidingen een passende keuze, voornamelijk voor de opleidingen die alleen bestaan voor het wo en niet voor het hbo. Dit is uiteindelijk ook terug te zien in de ONR2019, bijvoorbeeld bij de masteropleiding gezondheidszorg en de bacheloropleiding dienstverlening. De associate degree (Ad)opleidingen worden ingedeeld bij de bachelor. Voor een aparte weergave van de ad-opleidingen in de ONR2019 en de toepasbaarheid van de ONR2019 voor POA zijn er nog niet genoeg werkenden op de arbeidsmarkt. ${ }^{5}$ Daarnaast blijkt dat de beroepen waarin mensen met een Ad-opleiding terecht komen, de meeste overeenkomsten laten zien met de beroepen van hbo-bachelor opgeleiden.

\section{Opleidingsindeling}

De indeling van de ONR2019 is over het mbo, en over de bama, zowel naar richting als naar niveau, vergelijkbaar. Binnen een richting van het mbo of een richting van de bama kunnen verschillende niveaus onderscheiden worden en binnen elk niveau kunnen verschillende richtingen vergeleken worden. Tabel 1 geeft weer dat de ONR2019 uit 4 aggregatieniveaus bestaat: niveau, sector, subsector, en type. Zowel het vmbo, mbo1, mbo2, en mbo3 bestaat uit 5 sectoren, 8 subsectoren en 20 typen, inclusief overig. Door de omvang van het aantal werken en het aantal scholieren is de omvang van het mbo4 en de bachelor groter. De indeling van het mbo4 bestaat uit 5 sectoren, 8 subsectoren en 25 typen, inclusief overig. De bachelor bestaat uit 5 sectoren, 9 subsectoren en 27 typen, inclusief overig. De master bestaat uit 5 sectoren, 8 subsectoren en 22 typen, inclusief overig. Aan het einde van dit rapport wordt een volledig overzicht van de ONR2019 gegeven.

\footnotetext{
${ }^{5}$ Voor een analyse van de Ad-opleidingen, zie Allen, J., Belfi, B., Bijlsma, I., Fouarge, D., \& Peeters, T. (2019, te verschijnen). Ad-opleidingen:
} omvang en rendement. Maastricht: ROA. 
Tabel 1: de indeling van de ONR2019 naar niveaus

\begin{tabular}{|c|c|c|c|}
\hline $\begin{array}{l}\text { ONR2019 } \\
\text { Niveau }\end{array}$ & $\begin{array}{l}\text { ONR2019 } \\
\text { sector }\end{array}$ & $\begin{array}{l}\text { ONR2019 } \\
\text { subsector }\end{array}$ & $\begin{array}{l}\text { ONR2019 } \\
\text { type }\end{array}$ \\
\hline Basisonderwijs & 1 & 1 & 1 \\
\hline vmbo, mbo1 & 5 & 8 & 20 \\
\hline vmbo-g/t, havo-, vwo-onderbouw & 1 & 1 & 1 \\
\hline havo, vwo & 1 & 1 & 1 \\
\hline mbo2 & 5 & 8 & 20 \\
\hline mbo3 & 5 & 8 & 20 \\
\hline mbo4 & 5 & 8 & 25 \\
\hline hbo-, wo-bachelor & 5 & 9 & 27 \\
\hline hbo-, wo-master, doctor & 5 & 8 & 22 \\
\hline Totaal & 33 & 52 & 137 \\
\hline
\end{tabular}

In het vervolg van dit Technisch Rapport wordt in zoveel mogelijk detail voor het mbo en de bama omschreven hoe de opleidingsclassificatie tot stand is gekomen. In paragraaf 2 wordt ingegaan op het mbo, en in paragraaf 3 op de bama. Binnen POA worden geen gedetailleerde arbeidsmarktprognoses voor vmbo en mbo1 gepubliceerd. De volledige ONR2019 zoals deze gebruikt wordt binnen POA staat weergegeven in tabel 2 in de bijlage. Om de mogelijkheid voor toepassing van de ONR2019 voor het vmbo en mbo1 te behouden, is de toekenning van de ISCEDF2013-codes aan een opleiding van het mbo3 overgenomen voor het vmbo en mbo1 zonder controle of de ONR2019 op dit niveau aan de eisen van betrouwbaarheid voldoet (c.q. de omvang van deze groepen in de EBB en administratieve data). ${ }^{6}$ Deze indeling is weergegeven in tabel 3 in de bijlage. Voor het beschrijven van de herleiding van de ONR2019 wordt er daarom in dit rapport niet verder ingegaan op deze niveaus.

\section{Mbo}

Een belangrijke eis voor de opleidingsclassificatie is dat deze verenigbaar is voor de verschillende datasets die als input gelden voor de modellen die binnen POA gebruikt worden. Dit betekent dat zowel de administratieve data van DUO en de instroomcijfers van schoolverlaters, als de EBB moeten aansluiten bij de voorgestelde opleidingsclassificatie. Voor prognosemodellen van POA, wordt de EBB gebruikt voor de samenhang tussen sectoren, beroepen en opleidingen. De DUO-data wordt in combinatie met de referentieramingen van het Ministerie van OCW gebruikt voor het nieuwe aanbod (de instroom) van schoolverlaters naar opleiding op de arbeidsmarkt. In dit rapport wordt beschreven welke stappen genomen zijn om tot een opleidingsclassificatie te komen die de informatie uit de EBB en de administratieve data gebruikt, compatibel maakt, en samenvoegt.

\subsection{Mbo 3 en 4}

Stap 1: classificatie op basis van gediplomeerden in administratieve data

De opbouw van de classificatie voor mbo3 en mbo4 volgt uit de 'zwaartepunten' van opleidingen in ISCEDF2013codes. Hiervoor zijn de ISCEDF2013-codes gekoppeld aan administratieve data met het aantal gediplomeerden in 2017 per CREBO-code. Deze koppeling is echter niet een-op-een. Voor een ISCEDF2013-code wordt gekeken hoe groot het aantal gediplomeerden is in de administratieve data. Dit gebeurt op het niveau van de CREBOcoderingen en hoe deze CREBO-codes zijn ingedeeld in ISCEDF2013-codes volgens de referentieboeken van het CBS. De grootste CREBO-codes (opleidingen) binnen de ISCEDF2013-code, het zogenaamde zwaartepunt, wordt

\footnotetext{
${ }^{6}$ De reden dat dit niet gedaan is, is omdat er binnen het hele mbo een vergelijkbare indeling naar niveau en richting gehanteerd is. Veranderingen binnen 1 niveau moeten daardoor doorgevoerd worden naar de andere niveaus. Mochten er veranderingen nodig zijn binnen de richtingen van het vmbo, dan moeten deze ook doorgevoerd worden binnen de andere niveaus van het mbo, en dit is uitdrukkelijk niet de bedoeling omdat dit niet bruikbaar is binnen POA.
} 
overgenomen als leidende beroepsopleiding, of subgroep waarbij in deze stap zoveel mogelijk de benaming wordt overgenomen van de beroepsopleidingen die in de mbo-domeinstructuur voorkomen. De naam van de beroepsopleiding of subgroep van een ISCEDF2013 komt overeen met de grootste opleiding binnen dat field. De grootste opleiding is de opleiding die meer dan 60\% (en in een tweede stap 55\%) van de gediplomeerden heeft uit de administratieve data. De toekenning van de namen van de beroepsopleiding of subgroepen is gebaseerd op het aantal gediplomeerden van regulier bekostigde instellingen. Het komt voor dat opleidingen (verschillende CREBO-codes), ingedeeld worden in dezelfde ISCEDF2013-code, maar dat die opleidingen vervolgens tot een andere beroepsopleiding of subgroep behoren, c.q., een ISCEDF2013-code komt in meerdere subgroepen voor omdat er andere opleidingen aan ten grondslag liggen. Aangezien binnen de EBB alleen ISCEDF2013-codes gemeten worden, en deze dus niet op basis van onderliggende opleidingen toegewezen kan worden aan verschillenden subgroepen, moet in deze stap bij het bepalen van de zwaartepunten ook rekening gehouden worden met het feit dat een ISCEDF2013-code maar in één beroepsopleiding, subgroep of domein mag voorkomen.

\section{Stap 2 toepasbaarheid classificatie beroepsbevolking}

Door het toepassen van de zwaartepunten op basis van het aantal gediplomeerden, krijgen we een bestand voor alle mbo-opleidingen. Om een sluitende opleidingsclassificatie te krijgen om arbeidsmarktprognoses mee te maken, moet de opleidingsclassificatie ook toepasbaar zijn op de EBB. In de EBB worden respondenten bevraagd over hun hoogst behaalde opleidingsniveau en -richting. De opleidingen uit de EBB moeten gekoppeld worden aan de opleidingen die in stap 1 uit de administratieve data gehaald zijn. De meeste combinaties van opleidingsniveau en -richting zoals aangegeven door respondenten in de EBB, komt direct overeen met de opleidingen zoals in stap 1 geïdentificeerd. Maar er kunnen ook combinaties voorkomen die niet in stap 1 op basis van de administratieve data zijn geïdentificeerd. Het kan zijn dat opleidingen niet voorkomen in de administratieve data maar wel in de EBB om een van de volgende redenen:

De opleiding is gevolgd buiten het reguliere, door OCW bekostigd, onderwijs, zoals bedrijfstrainingen, particuliere opleidingen, maar ook bijvoorbeeld de opleiding in het leger of de politie.

De opleiding is in het buitenland gevolgd en komt daarom niet voor in de DUO-data.

De respondent geeft abusievelijke combinaties van niveau en richting die niet bestaan.

De respondent rapporteert een oude opleiding die nu niet meer voorkomt in de administratieve data van DUO.

De toekenning van opleidingen die wel voorkomen in de EBB maar niet in de administratieve data aan de in stap 1 bepaalde opleidingen is als volgt ${ }^{7}$ :

- $\quad$ Bij meer dan 10.000 gewogen observaties in de EBB: toekenning op basis van de samenhang tussen de onderliggende beroepenstructuur en in de EBB gemeten opleiding. Het gaat hierbij vaak om specifieke secretariële opleidingen op mbo3- en mbo4 -niveau, specifieke zorg en welzijn opleidingen op mbo3- en mbo4-niveau, en opleidingen van defensie en politie op mbo4-niveau.

- $\quad$ Bij minder dan 10 ongewogen observaties in de EBB: in dit geval kunnen de gegevens over opleiding en beroep op toeval berusten waardoor de uitspraken die op basis van deze observaties gedaan worden onbetrouwbaar zijn. Deze observaties worden in de categorie 'overig' op het niveau ingedeeld.

- $\quad$ Bij meer dan 10 ongewogen observaties in de EBB, maar minder dan 10.000 gewogen observaties: toekenning op basis van samenhang van de onderliggende beroepenstructuur. Voor alle opleidingen in de EBB hebben wij de beroepenstructuur in kaart gebracht. Door het vergelijken van de beroepenstructuur tussen alle opleidingen, delen wij de niet-toegekende observaties toe aan de indeling van de meest verwante opleiding in termen van de onderliggende beroepenstructuur. Hierbij wordt ook gekeken of het

\footnotetext{
7 Het geven van een kwantificering over het aantal opleidingen dat binnen stap 1 en 2 op elke manier is ingedeeld is niet zinvol. Het bestaan van een opleiding zegt namelijk niets over de omvang van deze opleiding in termen van werkenden (EBB) of gediplomeerden (DUO), hierdoor hebben opleidingen niet dezelfde weegfactor in het totaal aan opleidingen en zijn over het algemeen de opleidingen die in stap 2 nog ingedeeld moeten worden de kleinere opleidingen.
} 
logischer is om de toekenning op basis van de ISCEDF2013-code te doen. Hierbij is een individuele afweging gemaakt per opleiding per niveau.

Stap 3: aggregeren van classificatie naar voldoende observaties voor alle niveaus van de indeling

Om de uiteindelijke opleidingsclassificatie te krijgen, moet vervolgens gekeken worden welke subgroepen en beroepsopleidingen of combinaties, voldoende omvang hebben in EBB voor betrouwbare prognoses. De uiteindelijke ONR2019 maakt onderscheid tussen typen, subsectoren, en sectoren. Daarbij is de regel dat elke ONR2019sector uit meerde subsectoren bestaat, en elke subsector uit minimaal 2 ONR2019typen. In deze stap wordt de domeinindeling van het mbo en de naamgeving van de onderliggende subgroepen van een domein losgelaten ten behoeve van de vulling (genoeg werkenden en genoeg deelnemers die zorgen voor instroom van gediplomeerden) van de opleidingsclassificatie. Elke opleiding moet minimaal 10.000 werkenden hebben en een instroom die daarbij in verhouding staat.

\section{Stap 4: stroomlijnen toekenning ISCEDF2013-codes over verschillende niveaus en richtingen}

Omdat we voor de ONR2019 binnen alle niveaus van het mbo eenzelfde toewijzing van ISCEDF2013 naar een opleidingstype willen, en eenzelfde aggregatie van type naar subsector, wordt in deze stap een kwalitatieve controle van stap 1-3 uitgevoerd. Daar waar ISCEDF2013-codes op mbo-niveau 2, 3 of 4 anders ingedeeld zijn, wordt dit gelijk getrokken over alle niveaus op basis van de best passende indeling rekening houdend met de onderliggende opleidingen en de samenhang binnen de ONR2019niveaus. Ook de opleidingen die in de overige categorie vallen onder stap 2 worden zoveel mogelijk toegekend aan de ONR-type waarin de verwante ISCEDF2013-codes vallen. Binnen het mbo leidt deze stap tot een indeling die op subsector per niveau kan verschillen omdat bepaalde opleidingen enkel op één niveau gegeven worden, bijvoorbeeld voor gezondheidszorg en welzijn.

Stap 5: controle naamgeving van de classificatie naar onderliggende opleidingen (voornamelijk op het niveau van de ONRtype en ONRsubsector)

Als laatste is voor de hele ONR2019 op mbo-niveau gecontroleerd of de naamgeving op het niveau van de opleidingen overeenkomt met de onderliggende opleidingen en zijn aanpassingen uitgevoerd, zowel andere benamingen als een verandering van de indeling van ISCEDF2013-codes, waar dit niet het geval is. In overleg met het CBS en het UWV zijn namen en indelingen aangepast om een goede, representatieve weergave van de onderliggende opleidingen te krijgen. In deze laatste stap wordt dus niet gekeken of de benaming volgens de domeinstructuur het beste de ONR2019 weer geeft, maar of de ONR2019type de opleidingsnamen van de onderliggende opleidingen weergeeft.

\section{$2.2 \quad$ Mbo 2}

Het onderscheid tussen de niveaus 2 en 3 in het mbo is nu mogelijk dankzij de inspanning van CBS die een nieuwe opleidingsniveau indeling voor het mbo beschikbaar heeft gesteld in EBB. Voor het mbo2 wordt dezelfde indeling overgenomen als voor het mbo3. De mate van detail in de opleidingsrichtingen waarin gepubliceerd zal worden binnen POA is echter beperkter. 


\section{BAMA}

\subsection{Bachelor (hbo-, wo-bachelor en ad-opleidingen) en Master (hbo, wo-master, en doctor)}

\section{Stap 1: ISCEDF2013 broad- en narrow field indeling voor gediplomeerden in administratieve data}

De opleidingsclassificatie voor het hoger onderwijs is gebaseerd op de indeling van de ISCEDF2013. De ISCEDF2013 onderwijsrichtingen heten fields, met drie niveaus van detail, de broad-, narrow-, en detailed-fields. In de eerste stap wordt de indeling van de ISCEDF2013 gevolgd naar broad-, narrow-, en detailed-field indeling. Aan de administratieve data van gediplomeerden van DUO is de ISCEDF2013-indeling gekoppeld. Van de opleidingen (ISCEDF2013-codes) waarvoor in de administratieve data gediplomeerden voorkomen, wordt de naam van de detailed-field overgenomen voor de opleidingsclassificatie.

\section{Stap 2: toepasbaarheid classificatie beroepsbevolking}

Zoals ook bij het mbo, moet om een sluitende opleidingsclassificatie te krijgen om arbeidsmarktprognoses mee te maken, de opleidingsclassificatie ook toepasbaar zijn in de EBB. In de EBB worden respondenten gevraagd hun hoogst behaalde opleidingsniveau en -richting. De opleidingen uit de EBB moeten gekoppeld worden aan de opleidingen die in stap 1 uit de administratieve data gehaald zijn. Een groot aantal combinaties van opleidingsniveau en -richting zoals aangegeven door respondenten in de EBB, komt direct overeen met de opleidingen zoals in stap 1 geïdentificeerd. Maar er kunnen ook combinaties voorkomen die niet in stap 1 op basis van de administratieve data zijn geïdentificeerd. Het kan zijn dat opleidingen niet voorkomen in de administratieve data maar wel in de EBB om een van de volgende redenen:

- De opleiding is gevolgd buiten het regulier door OCW bekostig onderwijs, zoals bedrijfstrainingen, particuliere opleidingen, maar ook bijvoorbeeld het leger of de politie.

- De opleiding is in het buitenland gevolgd en komt daarom niet voor in de DUO-data.

- $\quad$ De respondent heeft abusievelijke een combinaties van niveau en richting opgegeven die niet bestaat.

De respondent heeft een oude opleiding die nu niet meer voorkomt in de administratieve data van DUO.

De toekenning van opleidingen die wel voorkomen in de EBB maar niet in de administratieve data aan de in stap 1 bepaalde opleidingen is als volgt ${ }^{8}$ :

- $\quad$ Bij meer dan 10.000 gewogen observaties in de EBB: toekenning op basis van de samenhang tussen de onderliggende beroepenstructuur en in de EBB gemeten opleiding. Het gaat hierbij vaak om specifieke secretariële opleidingen op mbo3- en mbo4 -niveau, specifieke zorg en welzijn opleidingen op mbo3- en mbo4-niveau, en opleidingen van defensie en politie op mbo4-niveau.

- $\quad$ Bij meer dan 10.000 gewogen observaties in de EBB: toekenning op basis van samenhang tussen de onderliggende beroepenstructuur en in de EBB gemeten opleiding.

- $\quad$ Bij minder dan 10 ongewogen observaties in de EBB kunnen de gegevens over opleiding en beroep op toeval berusten waardoor de uitspraken die op basis van deze observaties gedaan worden onbetrouwbaar zijn. Deze observaties worden in de categorie 'overig' op het niveau ingedeeld.

- $\quad$ Bij meer dan 10 ongewogen observaties in de EBB, maar minder dan 10.000 gewogen observaties: toekenning op basis van samenhang van de onderliggende beroepenstructuur. Voor alle opleidingen in de EBB hebben wij de beroepenstructuur in kaart gebracht. Door het vergelijken van de beroepenstructuur

\footnotetext{
8 Het geven van een kwantificering over het aantal opleidingen dat binnen stap 1 en 2 op elke manier is ingedeeld is niet zinvol. Het bestaan van een opleiding zegt namelijk niets over de omvang van deze opleiding in termen van werkenden (EBB) of gediplomeerden (DUO), hierdoor hebben opleidingen niet dezelfde weegfactor in het totaal aan opleidingen en zijn over het algemeen de opleidingen die in stap 2 nog ingedeeld moeten worden de kleinere opleidingen.
} 
tussen alle opleidingen, delen wij de niet-toegekende observaties toe aan de indeling van de meest verwante opleiding in termen van de onderliggende beroepenstructuur.

\section{Stap 3: aggregeren van classificatie naar voldoende observaties voor alle niveaus van de indeling}

Om de uiteindelijke opleidingsclassificatie te krijgen, moet vervolgens gekeken worden welke detailed- en narrowfields, of combinaties, leiden tot voldoende omvang om betrouwbare prognoses te kunnen doorrekenen. Als een ISCEDF2013 meer dan 10.000 observaties in de EBB heeft, dan wordt de naam van de detailed-field overgenomen, voor alle andere ISCEDF2013-codes wordt de narrow-field benaming overgenomen. Als het aantal observaties uit de EBB voor het totale narrow-field nog steeds minder is dan 10.000, dan worden narrow-fields binnen een broad-field samengevoegd op basis van de overeenkomst in de beroepenstructuur van de onderliggende opleidingen. Tot slot is er geaggregeerd binnen broad-fields om voldoende observaties voor de gediplomeerden in de administratieve data te krijgen per narrow-field. Het niveau van de detailed-field komt daarbij grofweg overeen met de ONR2019type, en de narrow-field met de ONR2019subsector. Daarbij is de regel dat elke ONR2019sector uit meerde subsectoren bestaat en elke subsector uit minimaal 2 ONR2019typen.

\section{Stap 4: stroomlijnen toekenning ISCEDF2013-codes over verschillende niveaus en richtingen}

Omdat we voor de ONR2019 binnen de bachelor en master streven naar eenzelfde toewijzing van ISCEDF2013codes naar een ONR-type, en naar eenzelfde aggregatie van ONR2019typen naar subsectoren, wordt in deze stap een kwalitatieve controle van stap 1-3 uitgevoerd. Daar waar ISCEDF2013-codes tussen bachelor- en masterniveau anders ingedeeld zijn, wordt dit gelijk getrokken over alle niveaus op basis van de best passende indeling rekening houdend met de onderliggende opleidingen en de samenhang binnen de ONR2019niveaus. Ook de opleidingen die in de overige categorie vallen onder stap 2 worden zoveel mogelijk toegekend aan de ONR2019type waarin de verwante ISCEDF2013-codes vallen. Daarbij komt in deze stap naar voren dat een aantal opleidingen die groot zijn op bachelor niveau en daardoor een eigen sectorindeling krijgen, niet voorkomen of heel klein zijn op masterniveau en vice versa. Dit leidt tot een indeling die op sommige punten afwijkt tussen bachelor en master, bijvoorbeeld voor subsector gezondheidszorg op masterniveau, en subsector dienstverlening op bachelor niveau.

Stap 5: controle naamlabels van de classificatie naar onderliggende opleidingen (voornamelijk op het niveau van de ONR2019type en ONR2019subsector)

Als laatste is voor de hele ONR2019 op bachelor- en master-niveau gecontroleerd of de naamgeving op het niveau van de opleidingen overeenkomt met de onderliggende opleidingen en is er afgestapt van de ISCEDF2013 naamgeving daar waar dit de onderliggende opleidingen niet goed weergeeft. Er zijn ook aanpassingen uitgevoerd van de indeling van ISCEDF2013-codes naar ONR2019 typen of subsectoren, waar dit niet het geval is. In overleg met het CBS en het UWV zijn namen aangepast om een goede, representatieve weergave van de onderliggende opleidingen te krijgen. In deze laatste stap wordt dus niet zozeer gekeken of de benaming volgens de ISCEDF2013indeling het beste de ONR2019 weer geeft, maar de opleidingsnamen van de onderliggende opleidingen. 


\section{Opleidingsclassificatie naar Niveau en Richting 2019 (ONR2019): Tabellen}

In de onderstaande tabellen staan voor verschillende toepassingen de volledige ONR2019 indeling weergegeven. In tabel 2 staat de classificatie zoals deze gebruikt wordt bij POA. In tabel 3 staat de volledige ONR2019 indeling. In tabel 4 staat de volledige ONR2019 inclusief de ISCEDF2013-codes. In tabel 5 staat een totaaloverzicht van de ONR2019 referentiebestanden met daarin de classificatie inclusief ISCEDF2013-codes en onderliggende CRcodes (CREBO- en CROHO-codes) en het aantal gediplomeerden in 2017-2018. 


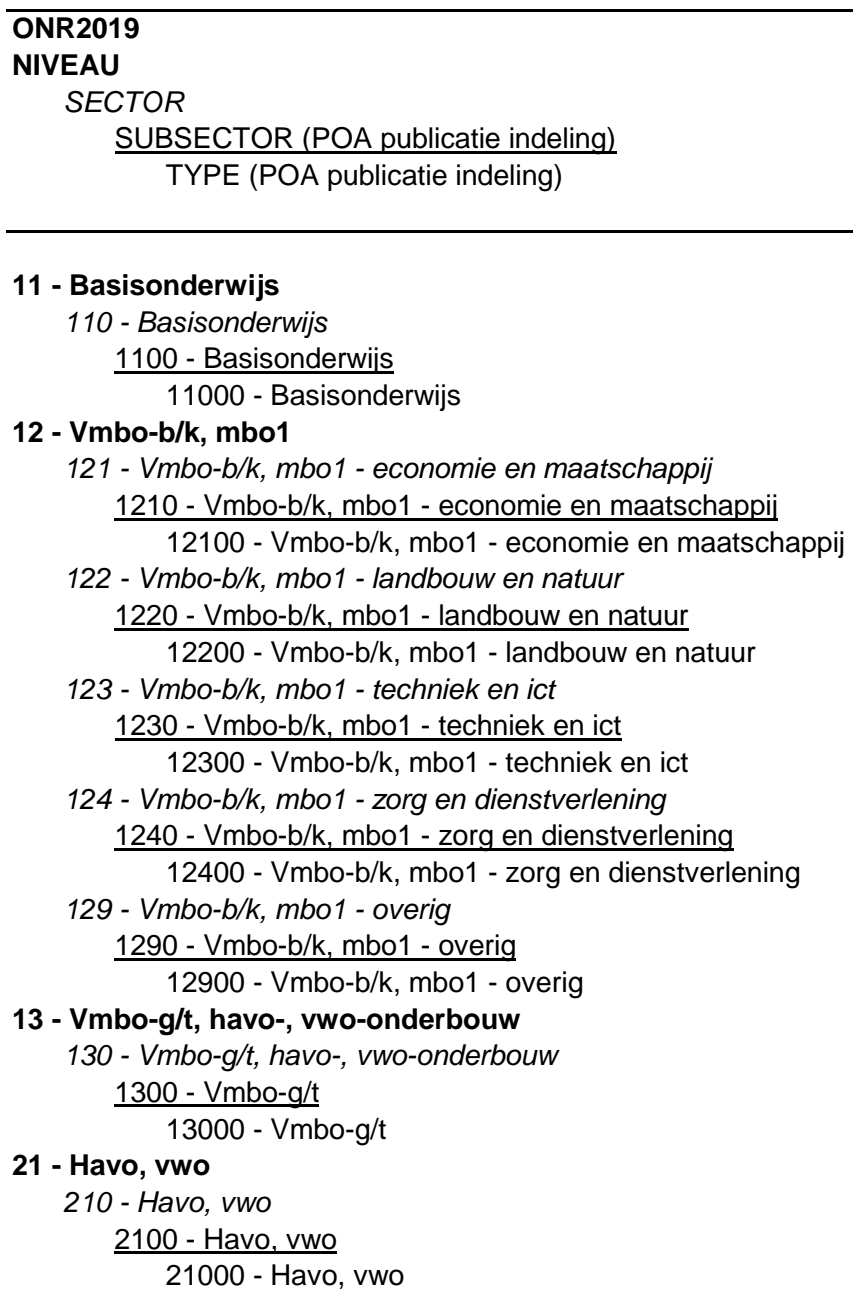

$$
21000 \text { - Havo, vwo }
$$

\section{2 - Mbo2}

221 - Mbo2 - economie en maatschappij

2210 - Mbo2 - economie en maatschappii

22100 - Mbo2 - economie en maatschappij

222 - Mbo2 - landbouw en natuur

2220 - Mbo2 - landbouw en natuur

22200 - Mbo2 - landbouw en natuur

223 - Mbo2 - techniek en ict

2230 - Mbo2 - techniek en ict

22300 - Mbo2 - techniek en ict

224 - Mbo2 - zorg en dienstverlening

2240 - Mbo2 - zorg en dienstverlening

22400 - Mbo2 - zorg en dienstverlening

229 - Mbo2 - overig

2290 - Mbo2 - overig

22900 - Mbo2 - overig

\section{3 - Mbo3}

231 - Mbo3 - economie en maatschappij

2311 - Mbo3 - economie en administratie

23111 - Mbo3 - financieel-administratieve dienstverlening

23112 - Mbo3 - secretariële dienstverlening

2312 - Mbo3 - handel, ondernemerschap, transport en logistiek

23121 - Mbo3 - detailhandel en groothandel

23122 - Mbo3 - transport en logistiek

232 - Mbo3 - landbouw en natuur

2321 - Mbo3 - voedsel, natuur en leefomgeving

23211 - Mbo3 - landbouw en dierverzorging

23212 - Mbo3 - slagerij, bakkerij, versindustrie

23213 - Mbo3 - tuinbouw en groenvoorziening 


\section{ONR2019 \\ NIVEAU \\ SECTOR \\ SUBSECTOR (POA publicatie indeling) \\ TYPE (POA publicatie indeling)}

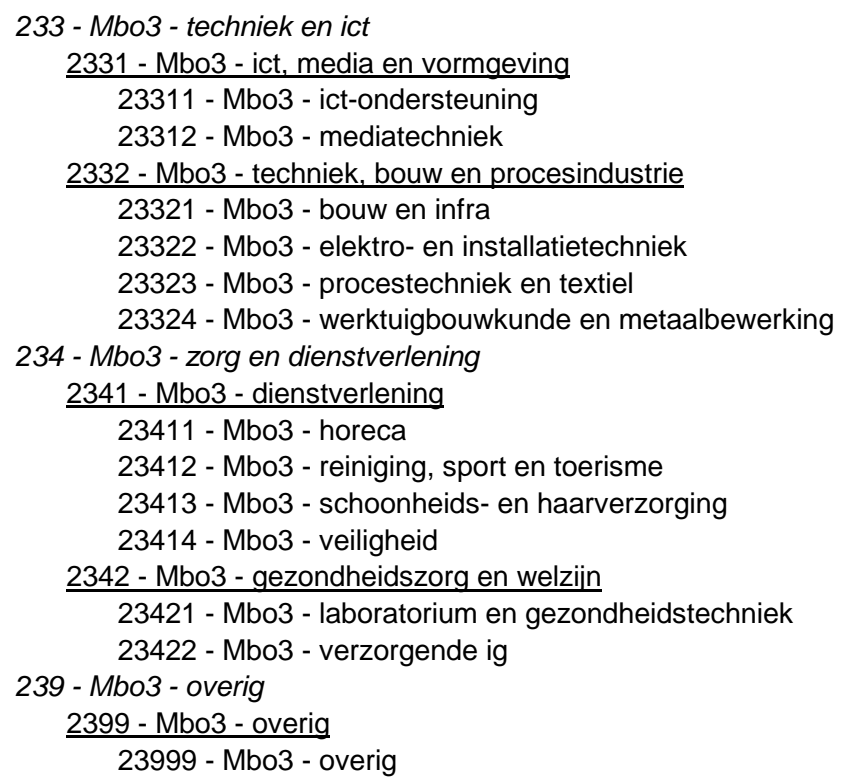

\section{4 - Mbo4}

241 - Mbo4 - economie en maatschappij

2411 - Mbo4 - economie en administratie

24111 - Mbo4 - commerciële dienstverlening

24112 - Mbo4 - financieel-administratieve dienstverlening

24113 - Mbo4 - juridisch-administratieve dienstverlening

24114 - Mbo4 - secretariële en algemene administratieve dienstverlening

$\underline{2412 \text { - Mbo4 - handel, ondernemerschap, transport en logistiek }}$

24121 - Mbo4 - management en ondernemerschap

24122 - Mbo4 - transport en logistiek

242 - Mbo4 - landbouw en natuur

2421 - Mbo4 - voedsel, natuur en leefomgeving

24211 - Mbo4 - landbouw en dierverzorging

24212 - Mbo4 - slagerij, bakkerij, versindustrie

24213 - Mbo4 - tuinbouw en groenvoorziening

243 - Mbo4 - techniek en ict

2431 - Mbo4 - ict, media en vormgeving

24311 - Mbo4 - ict- en mediabeheer

24312 - Mbo4 - mediavormgeving

2432 - Mbo4 - techniek, bouw en procesindustrie

24321 - Mbo4 - bouw en infra

24322 - Mbo4 - elektro- en installatietechniek

24323 - Mbo4 - procestechniek en textiel

24324 - Mbo4 - werktuigbouwkunde en metaalbewerking

244 - Mbo4 - zorg en dienstverlening

2441 - Mbo 4 - dienstverlening

24411 - Mbo4 - facilitaire dienstverlening

24412 - Mbo4 - horeca

24413 - Mbo4 - schoonheids- en haarverzorging

24414 - Mbo4 - sport en bewegen

24415 - Mbo4 - toerisme en recreatie

2442 - Mbo4 - gezondheidszorg en welzijn

24421 - Mbo4 - laboratorium en gezondheidstechniek

24422 - Mbo4 - pedagogisch werk

24423 - Mbo4 - sociaal en maatschappelijk werk

24424 - Mbo4 - verpleegkunde en medische ondersteuning

249 - Mbo4 - overig

2499 - Mbo4 - overig

24999 - Mbo4 - overig 


\author{
ONR2019 \\ NIVEAU \\ SECTOR \\ SUBSECTOR (POA publicatie indeling) \\ TYPE (POA publicatie indeling)
}

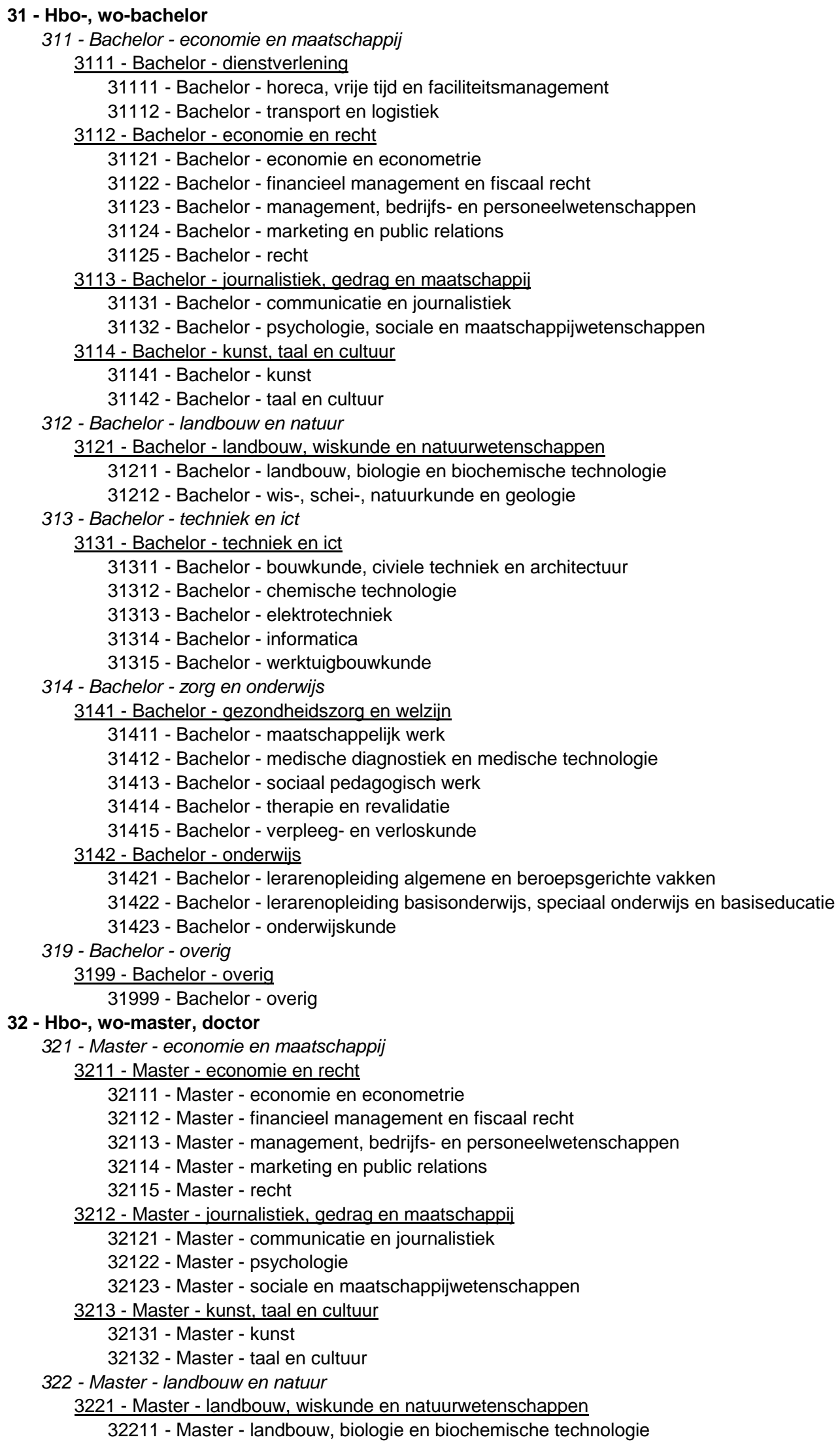




\section{ONR2019}

\section{NIVEAU}

SECTOR

SUBSECTOR ( $P O A$ publicatie indeling)

TYPE (POA publicatie indeling)

32212 - Master - wis-, schei-, natuurkunde en geologie

323 - Master - techniek en ict

3231 - Master - techniek en ict

32311 - Master - bouwkunde, civiele techniek en architectuur

32312 - Master - chemische technologie

32313 - Master - elektrotechniek

32314 - Master - informatica

32315 - Master - werktuigbouwkunde

324 - Master - zorg en onderwijs

3241 - Master - gezondheidszorg

32411 - Master - (dier)geneeskunde en tandheelkunde

32412 - Master - farmacie en gezondsheidswetenschappen

3242 - Master - onderwijs

32421 - Master - lerarenopleiding algemene en beroepsgerichte vakken

32422 - Master - onderwijskunde en pedagogische wetenschappen

329 - Master - overig

3299 - Master - overig

32999 - Master - overig

\section{9 - Onderwijs overig}

999 - Onderwijs overig

9999 - Onderwijs overig

99999 - Onderwijs overig 


\begin{tabular}{l} 
ONR2019 \\
NIVEAU \\
SECTOR \\
$\quad \frac{\text { SUBSECTOR }}{\text { TYPE }}$ \\
\hline
\end{tabular}

\section{1 - Basisonderwijs \\ 110 - Basisonderwijs \\ 1100 - Basisonderwijs \\ 11000 - Basisonderwijs}

12 - Vmbo-b/k, mbo1

121 - Vmbo-b/k, mbo1 - economie en maatschappij

1211 - Vmbo-b/k, mbo1 - economie en administratie

12111 - Vmbo-b/k, mbo1 - financieel-administratieve dienstverlening

12112 - Vmbo-b/k, mbo1 - secretariële dienstverlening

1212 - Vmbo-b/k, mbo1 - handel, ondernemerschap, transport en logistiek

12121 - Vmbo-b/k, mbo1 - detailhandel en groothandel

12122 - Vmbo-b/k, mbo1 - transport en logistiek

122 - Vmbo-b/k, mbo1 - landbouw en natuur

1221 - Vmbo-b/k, mbo1 - voedsel, natuur en leefomgeving

12211 - Vmbo-b/k, mbo1 - landbouw en dierverzorging

12212 - Vmbo-b/k, mbo1 - slagerij, bakkerij, versindustrie

12213 - Vmbo-b/k, mbo1 - tuinbouw en groenvoorziening

123 - Vmbo-b/k, mbo1 - techniek en ict

$1231-V m b o-b / k$, mbo1 - ict, media en vormgeving

12311 - Vmbo-b/k, mbo1 - ict-ondersteuning

12312 - Vmbo-b/k, mbo1 - mediatechniek

1232 - Vmbo-b/k, mbo1 - techniek, bouw en procesindustrie

12321 - Vmbo-b/k, mbo1 - bouw en infra

12322 - Vmbo-b/k, mbo1 - elektro- en installatietechniek

12323 - Vmbo-b/k, mbo1 - procestechniek en textiel

12324 - Vmbo-b/k, mbo1 - werktuigbouwkunde en metaalbewerking

124 - Vmbo-b/k, mbo1 - zorg en dienstverlening

1241 - Vmbo-b/k, mbo1 - dienstverlening

12411 - Vmbo-b/k, mbo1 - horeca

12412 - Vmbo-b/k, mbo1 - reiniging, sport en toerisme

12413 - Vmbo-b/k, mbo1 - schoonheids- en haarverzorging

12414 - Vmbo-b/k, mbo1 - veiligheid

1242 - Vmbo-b/k, mbo1 - gezondheidszorg en welzijn

12421 - Vmbo-b/k, mbo1 - helpende zorg en welzijn

12422 - Vmbo-b/k, mbo1 - laboratorium en gezondheidstechniek

129 - Vmbo-b/k, mbo1 - overig

1299 - Vmbo-b/k, mbo1 - overig

12999 - Vmbo-b/k, mbo1 - overig

13 - Vmbo-g/t, havo-, vwo-onderbouw

130 - Vmbo-g/t, havo-, vwo-onderbouw

1300 - Vmbo-g/t, havo-, vwo-onderbouw

13000 - Vmbo-g/t, havo-, vwo-onderbouw

\section{1 - Havo, vwo}

210 - Havo, vwo

2100 - Havo, vwo

22 - Mbo2

21000 - Havo, vwo

221 - Mbo2 - economie en maatschappij

2211 - Mbo2 - economie en administratie

22111 - Mbo2 - financieel-administratieve dienstverlening

22112 - Mbo2 - secretariële dienstverlening

2212 - Mbo2 - handel, ondernemerschap, transport en logistiek

22121 - Mbo2 - detailhandel en groothandel

22122 - Mbo2 - transport en logistiek

222 - Mbo2 - landbouw en natuur

2221 - Mbo2 - voedsel, natuur en leefomgeving

22211 - Mbo2 - landbouw en dierverzorging

22212 - Mbo2 - slagerij, bakkerij, versindustrie

22213 - Mbo2 - tuinbouw en groenvoorziening 


\begin{tabular}{l} 
ONR2019 \\
NIVEAU \\
SECTOR \\
$\quad \frac{\text { SUBSECTOR }}{\text { TYPE }}$ \\
\hline
\end{tabular}

223 - Mbo2 - techniek en ict

2231 - Mbo2 - ict, media en vormgeving

22311 - Mbo2 - ict-ondersteuning

22312 - Mbo2 - mediatechniek

2232 - Mbo2 - techniek, bouw en procesindustrie

22321 - Mbo2 - bouw en infra

22322 - Mbo2 - elektro- en installatietechniek

22323 - Mbo2 - procestechniek en textiel

22324 - Mbo2 - werktuigbouwkunde en metaalbewerking

224 - Mbo2 - zorg en dienstverlening

2241 - Mbo2 - dienstverlening

22411 - Mbo2 - horeca

22412 - Mbo2 - reiniging, sport en toerisme

22413 - Mbo2 - schoonheids- en haarverzorging

22414 - Mbo2 - veiligheid

2242 - Mbo2 - gezondheidszorg en welzijn

22421 - Mbo2 - helpende zorg en welzijn

22422 - Mbo2 - laboratorium en gezondheidstechniek

229 - Mbo2 - overig

2299 - Mbo2 - overig

22999 - Mbo2 - overig

\section{$23-\mathrm{Mbo3}$}

231 - Mbo3 - economie en maatschappij

2311 - Mbo3 - economie en administratie

23111 - Mbo3 - financieel-administratieve dienstverlening

23112 - Mbo3 - secretariële dienstverlening

2312 - Mbo3 - handel, ondernemerschap, transport en logistiek

23121 - Mbo3 - detailhandel en groothandel

23122 - Mbo3 - transport en logistiek

232 - Mbo3 - landbouw en natuur

2321 - Mbo3 - voedsel, natuur en leefomgeving

23211 - Mbo3 - landbouw en dierverzorging

23212 - Mbo3 - slagerij, bakkerij, versindustrie

23213 - Mbo3 - tuinbouw en groenvoorziening

233 - Mbo3 - techniek en ict

2331 - Mbo3 - ict, media en vormgeving

23311 - Mbo3 - ict-ondersteuning

23312 - Mbo3 - mediatechniek

2332 - Mbo3 - techniek, bouw en procesindustrie

23321 - Mbo3 - bouw en infra

23322 - Mbo3 - elektro- en installatietechniek

23323 - Mbo3 - procestechniek en textiel

23324 - Mbo3 - werktuigbouwkunde en metaalbewerking

234 - Mbo3 - zorg en dienstverlening

2341 - Mbo3 - dienstverlening

23411 - Mbo3 - horeca

23412 - Mbo3 - reiniging, sport en toerisme

23413 - Mbo3 - schoonheids- en haarverzorging

23414 - Mbo3 - veiligheid

2342 - Mbo3 - gezondheidszorg en welzijn

23421 - Mbo3 - laboratorium en gezondheidstechniek

23422 - Mbo3 - verzorgende ig

239 - Mbo3 - overig

2399 - Mbo3 - overig

23999 - Mbo3 - overig

$24-\mathrm{Mbo} 4$

241 - Mbo4 - economie en maatschappij

2411 - Mbo4 - economie en administratie

24111 - Mbo4 - commerciële dienstverlening

24112 - Mbo4 - financieel-administratieve dienstverlening 


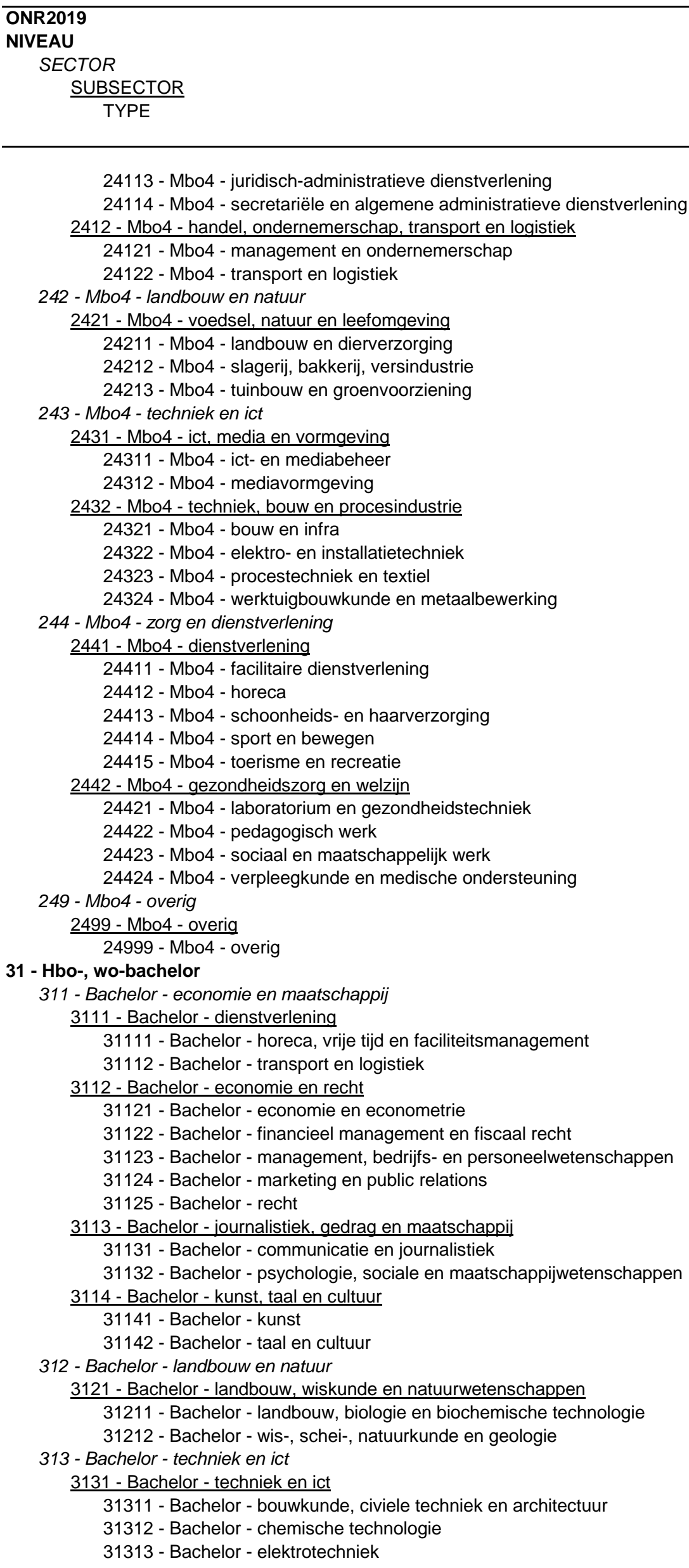




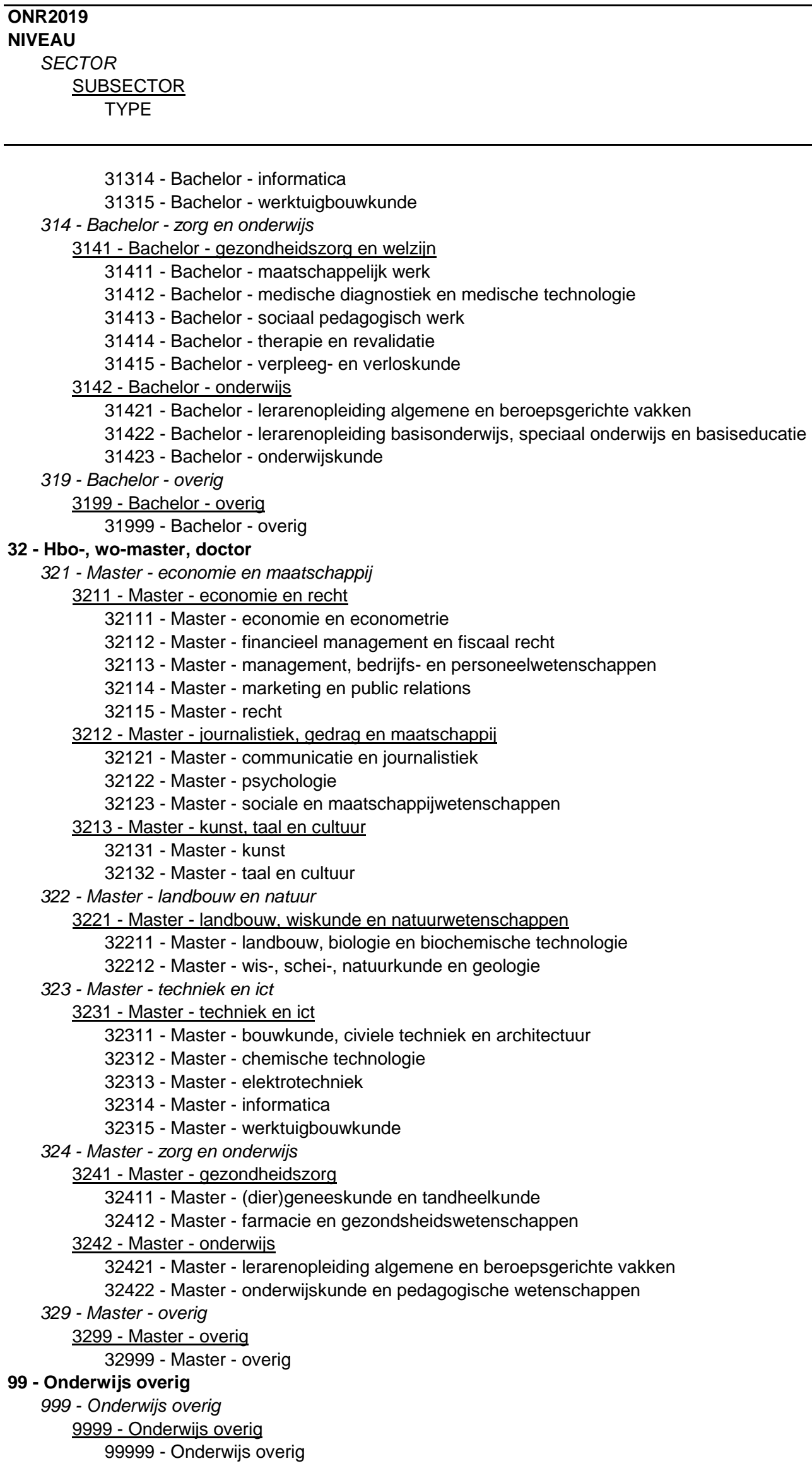




\begin{tabular}{l} 
ONR2019 \\
NIVEAU \\
SECTOR \\
$\quad \begin{array}{l}\text { SUBSECTOR } \\
\text { TYPE } \\
\text { ISCEDF2013 }\end{array}$ \\
\hline
\end{tabular}

\author{
11 - Basisonderwijs \\ 110 - Basisonderwijs \\ 1100 - Basisonderwijs \\ 11000 - Basisonderwijs
}

12 - Vmbo-b/k, mbo1

121 - Vmbo-b/k, mbo1 - economie en maatschappij

1211 - Vmbo-b/k, mbo1 - economie en administratie

12111 - Vmbo-b/k, mbo1 - financieel-administratieve dienstverlening

0411 - financieel management en fiscaal recht

0412 - financiële dienstverlening

0420 - recht

0421 - recht

12112 - Vmbo-b/k, mbo1 - secretariële dienstverlening

0322 - bibliotheek, documentaire informatievoorziening

0410 - bedrijfskunde en administratie

0413 - management bedrijfs- en personeelswetenschappen

0414 - marketing en public relations

0415 - secretariële en administratieve ondersteuning

0417 - werkgerelateerde en bedriffsgerichte trainingen

1212 - Vmbo-b/k, mbo1 - handel, ondernemerschap, transport en logistiek

12121 - Vmbo-b/k, mbo1 - detailhandel en groothandel

0416 - groothandel en detailhandel

12122 - Vmbo-b/k, mbo1 - transport en logistiek

0830 - visserij

0831 - visserij

1040 - transport en logistiek

1041 - transport en logistiek

122 - Vmbo-b/k, mbo1 - landbouw en natuur

$1221-\mathrm{Vmbo}-\mathrm{b} / \mathrm{k}, \mathrm{mbo} 1$ - voedsel, natuur en leefomgeving

12211 - Vmbo-b/k, mbo1 - landbouw en dierverzorging

0810 - landbouw

0811 - landbouw en veeteelt

12212 - Vmbo-b/k, mbo1 - slagerij, bakkerij, versindustrie

0214 - kunstnijverheid

0720 - levensmiddelentechnologie- en non-ferrotechniek

0721 - levensmiddelentechnologie

12213 - Vmbo-b/k, mbo1 - tuinbouw en groenvoorziening

0712 - milieubescherming en milieutechnologie

0812 - tuinbouw

0820 - bosbouw

0821 - bosbouw

123 - Vmbo-b/k, mbo1 - techniek en ict

$1231-V m b o-b / k, m b o 1$ - ict, media en vormgeving

12311 - Vmbo-b/k, mbo1 - ict-ondersteuning

0600 - informatica

0610 - informatica

0611 - computergebruik

0612 - ontwerp en beheer van database en netwerken

0613 - softwareontwikkeling en systeemanalyse

0619 - informatica overig

12312 - Vmbo-b/k, mbo1 - mediatechniek

0210 - kunst

0211 - audiovisuele techniek en mediaproductie

0212 - mode-, interieur- en industriële vormgeving

0213 - beeldende kunst, kunstgeschiedenis

0215 - muziek en theater 


ONR2019
NIVEAU
SECTOR
$\quad \frac{\text { SUBSECTOR }}{\text { TYPE }}$
$\quad$ ISCEDF2013

1232 - Vmbo-b/k, mbo1 - techniek, bouw en procesindustrie

12321 - Vmbo-b/k, mbo1 - bouw en infra

0730 - architectuur en bouwkunde

0731 - architectuur en stedebouwkunde

0732 - bouwkunde en civiele techniek

12322 - Vmbo-b/k, mbo1 - elektro- en installatietechniek

0700 - techniek, industrie en bouwkunde

0710 - techniek en technische dienstverlening

0713 - elektro- en energietechniek

0714 - elektronica en industriële automatisering

12323 - Vmbo-b/k, mbo1 - procestechniek en textiel

0711 - scheikundige technologie en procestechniek

0723 - textiel-, kleding-, schoenen-, en leervervaardiging

0724 - delfstofwinning

12324 - Vmbo-b/k, mbo1 - werktuigbouwkunde en metaalbewerking

0715 - werktuigbouwkunde en metaalbewerking

0716 - voertuigtechniek, scheepsbouw- en vliegtuigbouwkunde

0722 - houtbewerking, papier-, kunsttofverwerking, keramiek

124 - Vmbo-b/k, mbo1 - zorg en dienstverlening

1241 - Vmbo-b/k, mbo1 - dienstverlening

12411 - Vmbo-b/k, mbo1 - horeca

1013 - horeca

12412 - Vmbo-b/k, mbo1 - reiniging, sport en toerisme

1010 - persoonlijke dienstverlening

1011 - huishoudkunde, facilitiare dienstverlening en reiniging

1014 - sport

1015 - toerisme en vrijetijdsbesteding

1020 - hygiëne en arbeidsomstandigheden

1021 - openbare reiniging, waterbeheer en -distributie

1022 - veiligheid op het werk en ergonomie

12413 - Vmbo-b/k, mbo1 - schoonheids- en haarverzorging

1012 - schoonheids- en haarverzorging

12414 - Vmbo-b/k, mbo1 - veiligheid

1030 - openbare veiligheid

1031 - krijgsmacht

1032 - openbare orde en veiligheid

1242 - Vmbo-b/k, mbo1 - gezondheidszorg en welzijn

12421 - Vmbo-b/k, mbo1 - helpende zorg en welzijn

0840 - diergeneeskunde en -verzorging

0841 - diergeneeskunde en -verzorging

0900 - gezondheidszorg en welzijn

0910 - gezondheidszorg

0912 - geneeskunde

0913 - verpleeg- en verloskunde

0916 - farmacie

0917 - traditionele en alternatieve geneeskunde en therapie

0920 - welzijn

0921 - gehandicaptenzorg voor volwassenen en bejaarden- en gezinszorg

0922 - jeugdpedagogisch werk en kinderverzorging

0923 - maatschappelijk werk en beroepskeuzewerk

12422 - Vmbo-b/k, mbo1 - laboratorium en gezondheidstechniek

0911 - tandheelkunde

0914 - medische diagnostiek en medische technologie

0915 - therapie en revalidatie

129 - Vmbo-b/k, mbo1 - overig

1299 - Vmbo-b/k, mbo1 - overig 


ONR2019
NIVEAU
SECTOR
$\quad \begin{aligned} & \text { SUBSECTOR } \\ & \text { TYPE } \\ & \text { ISCEDF2013 }\end{aligned}$

12999 - Vmbo-b/k, mbo1 - overig

0000 - algemeen

0010 - algemeen

0011 - algemeen

0020 - basiseducatie, alfabetisering

0021 - basiseducatie, alfabetisering

0030 - persoonlijke ontplooiing

0031 - persoonlijke ontplooiing

0100 - onderwijs

0110 - onderwijskunde, lerarenopleidingen en pedagogisch-didactische cursussen

0111 - onderwijskunde

0112 - opleiding kleuterleidsters

0113 - lerarenopleiding basisonderwijs, speciaal onderwijs en basiseducatie

0114 - lerarenopleiding algemene en beroepsgerichte vakken

0200 - vormgeving, kunst, talen en geschiedenis

0220 - geesteswetenschappen

0221 - theologie, levensbeschouwing

0222 - geschiedenis, archeologie

0223 - filosofie en ethiek

0230 - talen

0231 - vreemde talen

0232 - moedertaal, literatuur-, taalwetenschap

0300 - journalistiek, gedrag en maatschappij

0310 - gedrag en maatschappij

0311 - economie en econometrie

0312 - politicologie en maatschappijwetenschappen

0313 - psychologie

0314 - sociologie en culturele wetenschappen

0320 - journalistiek, informatievoorziening

0321 - journalistiek

0400 - recht, administratie, handel en zakelijke dienstverlening

0500 - wiskunde, natuurwetenschappen

0510 - biologie en biochemie

0511 - biologie

0512 - biochemie

0520 - milieu en natuurbeheer

0521 - milieu

0522 - natuurbeheer

0530 - natuurwetenschappen

0531 - scheikunde

0532 - aardwetenschappen

0533 - natuurkunde

0540 - wiskunde en statistiek

0541 - wiskunde

0542 - statistiek

0800 - landbouw, diergeneeskunde en -verzorging

0818 - interdisciplinaire opleidingen landbouw

0919 - gezondheidszorg overig

1000 - dienstverlening

9990 - onbekend of niet gespecifieerd

9997 - niet van toepassing

9998 - weet niet of onbekend

9999 - onbekend of niet gespecifieerd

13 - Vmbo-g/t, havo-, vwo-onderbouw

130 - Vmbo-g/t, havo-, vwo-onderbouw

1300 - Vmbo-g/t, havo-, vwo-onderbouw 


ONR2019
NIVEAU
SECTOR
$\quad \frac{\text { SUBSECTOR }}{\text { TYPE }}$
$\quad$ ISCEDF2013

13000 - Vmbo-g/t, havo-, vwo-onderbouw

21 - Havo, vwo

210 - Havo, vwo

2100 - Havo, vwo

21000 - Havo, vwo

$22-\mathrm{Mbo2}$

221 - Mbo2 - economie en maatschappij

2211 - Mbo2 - economie en administratie

22111 - Mbo2 - financieel-administratieve dienstverlening

0411 - financieel management en fiscaal recht

0412 - financiële dienstverlening

0420 - recht

0421 - recht

22112 - Mbo2 - secretariële dienstverlening

0322 - bibliotheek, documentaire informatievoorziening

0410 - bedrijfskunde en administratie

0413 - management bedrijfs- en personeelswetenschappen

0414 - marketing en public relations

0415 - secretariële en administratieve ondersteuning

0417 - werkgerelateerde en bedrijfsgerichte trainingen

2212 - Mbo2 - handel, ondernemerschap, transport en logistiek

22121 - Mbo2 - detailhandel en groothandel

0416 - groothandel en detailhandel

22122 - Mbo2 - transport en logistiek

0830 - visserij

0831 - visserij

1040 - transport en logistiek

1041 - transport en logistiek

222 - Mbo2 - landbouw en natuur

2221 - Mbo2 - voedsel, natuur en leefomgeving

22211 - Mbo2 - landbouw en dierverzorging

0810 - landbouw

0811 - landbouw en veeteelt

22212 - Mbo2 - slagerij, bakkerij, versindustrie

0214 - kunstnijverheid

0720 - levensmiddelentechnologie- en non-ferrotechniek

0721 - levensmiddelentechnologie

22213 - Mbo2 - tuinbouw en groenvoorziening

0712 - milieubescherming en milieutechnologie

0812 - tuinbouw

0820 - bosbouw

0821 - bosbouw

223 - Mbo2 - techniek en ict

2231 - Mbo2 - ict, media en vormgeving

22311 - Mbo2 - ict-ondersteuning

0600 - informatica

0610 - informatica

0611 - computergebruik

0612 - ontwerp en beheer van database en netwerken

0613 - softwareontwikkeling en systeemanalyse

0619 - informatica overig

22312 - Mbo2 - mediatechniek

0210 - kunst

0211 - audiovisuele techniek en mediaproductie

0212 - mode-, interieur- en industriële vormgeving

0213 - beeldende kunst, kunstgeschiedenis 


ONR2019
NIVEAU
SECTOR
$\quad \frac{\text { SUBSECTOR }}{\text { TYPE }}$
$\quad$ ISCEDF2013

0215 - muziek en theater

2232 - Mbo2 - techniek, bouw en procesindustrie

22321 - Mbo2 - bouw en infra

0730 - architectuur en bouwkunde

0731 - architectuur en stedebouwkunde

0732 - bouwkunde en civiele techniek

22322 - Mbo2 - elektro- en installatietechniek

0700 - techniek, industrie en bouwkunde

0710 - techniek en technische dienstverlening

0713 - elektro- en energietechniek

0714 - elektronica en industriële automatisering

22323 - Mbo2 - procestechniek en textiel

0711 - scheikundige technologie en procestechniek

0723 - textiel-, kleding-, schoenen-, en leervervaardiging

0724 - delfstofwinning

22324 - Mbo2 - werktuigbouwkunde en metaalbewerking

0715 - werktuigbouwkunde en metaalbewerking

0716 - voertuigtechniek, scheepsbouw- en vliegtuigbouwkunde

0722 - houtbewerking, papier-, kunsttofverwerking, keramiek

224 - Mbo2 - zorg en dienstverlening

2241 - Mbo2 - dienstverlening

22411 - Mbo2 - horeca

1013 - horeca

22412 - Mbo2 - reiniging, sport en toerisme

1010 - persoonlijke dienstverlening

1011 - huishoudkunde, facilitiare dienstverlening en reiniging

1014 - sport

1015 - toerisme en vrijetijdsbesteding

1020 - hygiëne en arbeidsomstandigheden

1021 - openbare reiniging, waterbeheer en -distributie

1022 - veiligheid op het werk en ergonomie

22413 - Mbo2 - schoonheids- en haarverzorging

1012 - schoonheids- en haarverzorging

22414 - Mbo2 - veiligheid

1030 - openbare veiligheid

1031 - krijgsmacht

1032 - openbare orde en veiligheid

2242 - Mbo2 - gezondheidszorg en welzijn

22421 - Mbo2 - helpende zorg en welzijn

0840 - diergeneeskunde en -verzorging

0841 - diergeneeskunde en -verzorging

0900 - gezondheidszorg en welzijn

0910 - gezondheidszorg

0912 - geneeskunde

0913 - verpleeg- en verloskunde

0916 - farmacie

0917 - traditionele en alternatieve geneeskunde en therapie

0920 - welzijn

0921 - gehandicaptenzorg voor volwassenen en bejaarden- en gezinszorg

0922 - jeugdpedagogisch werk en kinderverzorging

0923 - maatschappelijk werk en beroepskeuzewerk

22422 - Mbo2 - laboratorium en gezondheidstechniek

0911 - tandheelkunde

0914 - medische diagnostiek en medische technologie

0915 - therapie en revalidatie

229 - Mbo2 - overig 


ONR2019
NIVEAU
SECTOR
$\quad \begin{aligned} & \text { SUBSECTOR } \\ & \text { TYPE } \\ & \text { ISCEDF2013 }\end{aligned}$

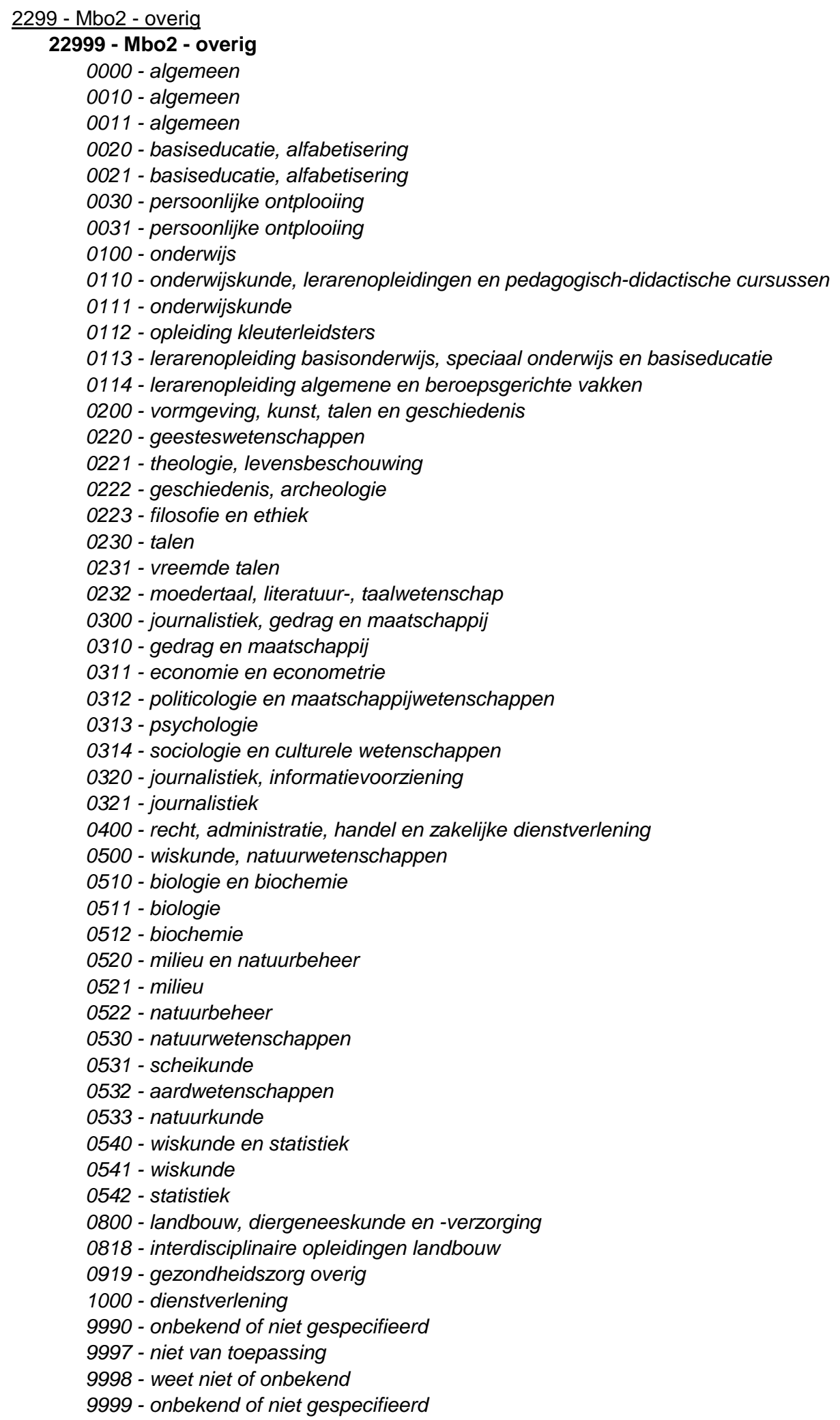

23 - Mbo3

231 - Mbo3 - economie en maatschappij 


ONR2019
NIVEAU
SECTOR
$\quad \frac{\text { SUBSECTOR }}{\text { TYPE }}$
$\quad$ ISCEDF2013

2311 - Mbo3 - economie en administratie

23111 - Mbo3 - financieel-administratieve dienstverlening

0411 - financieel management en fiscaal recht

0412 - financiële dienstverlening

0420 - recht

0421 - recht

23112 - Mbo3 - secretariële dienstverlening

0322 - bibliotheek, documentaire informatievoorziening

0410 - bedrijfskunde en administratie

0413 - management bedrijfs- en personeelswetenschappen

0414 - marketing en public relations

0415 - secretariële en administratieve ondersteuning

0417 - werkgerelateerde en bedrijfsgerichte trainingen

2312 - Mbo3 - handel, ondernemerschap, transport en logistiek

23121 - Mbo3 - detailhandel en groothandel

0416 - groothandel en detailhandel

23122 - Mbo3 - transport en logistiek

0830 - visserij

0831 - visserij

1040 - transport en logistiek

1041 - transport en logistiek

232 - Mbo3 - landbouw en natuur

2321 - Mbo3 - voedsel, natuur en leefomgeving

23211 - Mbo3 - landbouw en dierverzorging

0810 - landbouw

0811 - landbouw en veeteelt

23212 - Mbo3 - slagerij, bakkerij, versindustrie

0214 - kunstnijverheid

0720 - levensmiddelentechnologie- en non-ferrotechniek

0721 - levensmiddelentechnologie

23213 - Mbo3 - tuinbouw en groenvoorziening

0712 - milieubescherming en milieutechnologie

0812 - tuinbouw

0820 - bosbouw

0821 - bosbouw

233 - Mbo3 - techniek en ict

2331 - Mbo3 - ict, media en vormgeving

23311 - Mbo3 - ict-ondersteuning

0600 - informatica

0610 - informatica

0611 - computergebruik

0612 - ontwerp en beheer van database en netwerken

0613 - softwareontwikkeling en systeemanalyse

0619 - informatica overig

23312 - Mbo3 - mediatechniek

0210 - kunst

0211 - audiovisuele techniek en mediaproductie

0212 - mode-, interieur- en industriële vormgeving

0213 - beeldende kunst, kunstgeschiedenis

0215 - muziek en theater

2332 - Mbo3 - techniek, bouw en procesindustrie

23321 - Mbo3 - bouw en infra

0730 - architectuur en bouwkunde

0731 - architectuur en stedebouwkunde

0732 - bouwkunde en civiele techniek

23322 - Mbo3 - elektro- en installatietechniek 


ONR2019
NIVEAU
SECTOR
$\quad \frac{\text { SUBSECTOR }}{\text { TYPE }}$
$\quad$ ISCEDF2013

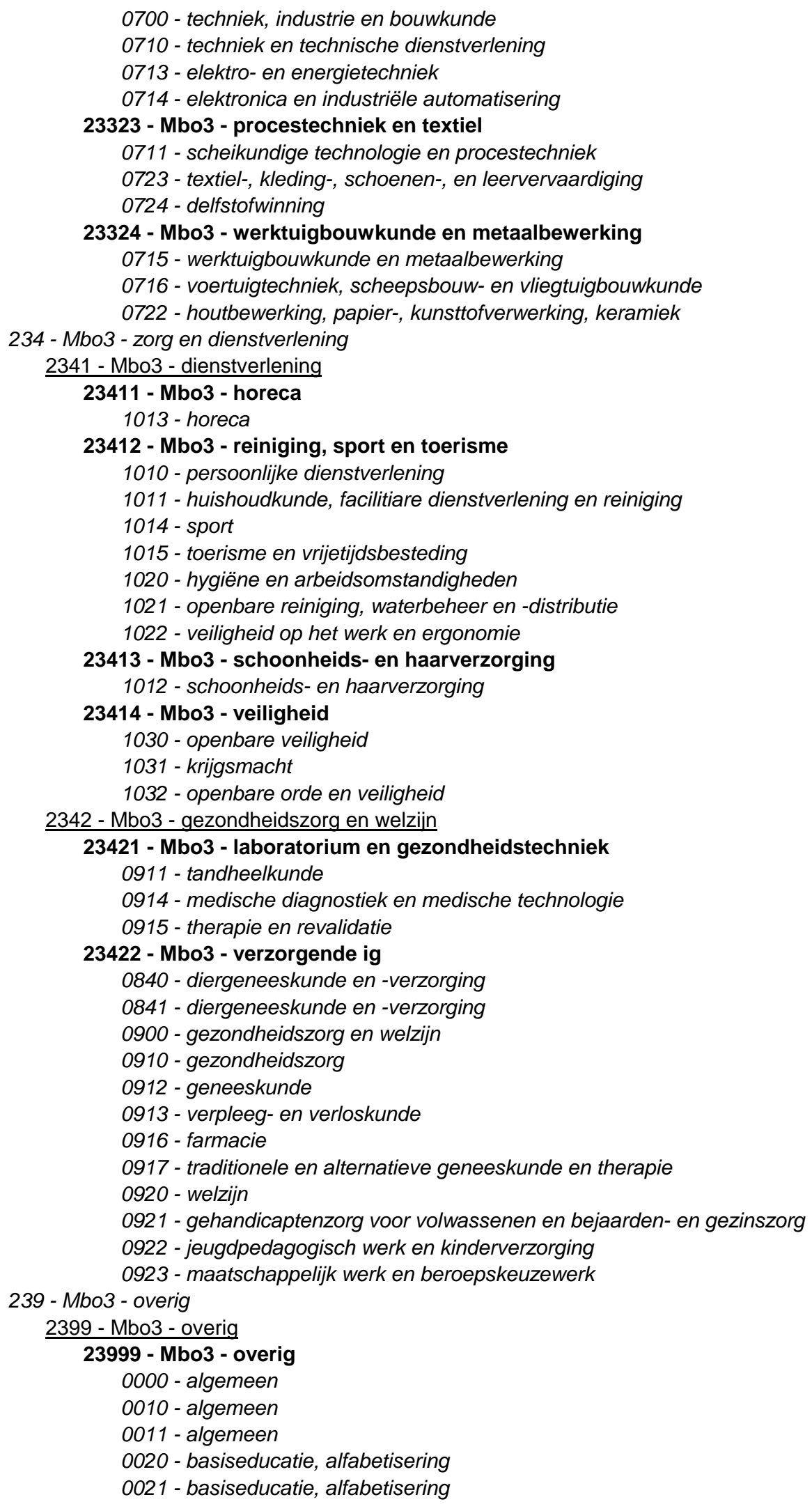




ONR2019
NIVEAU
SECTOR
$\quad \frac{\text { SUBSECTOR }}{\text { TYPE }}$
$\quad$ ISCEDF2013

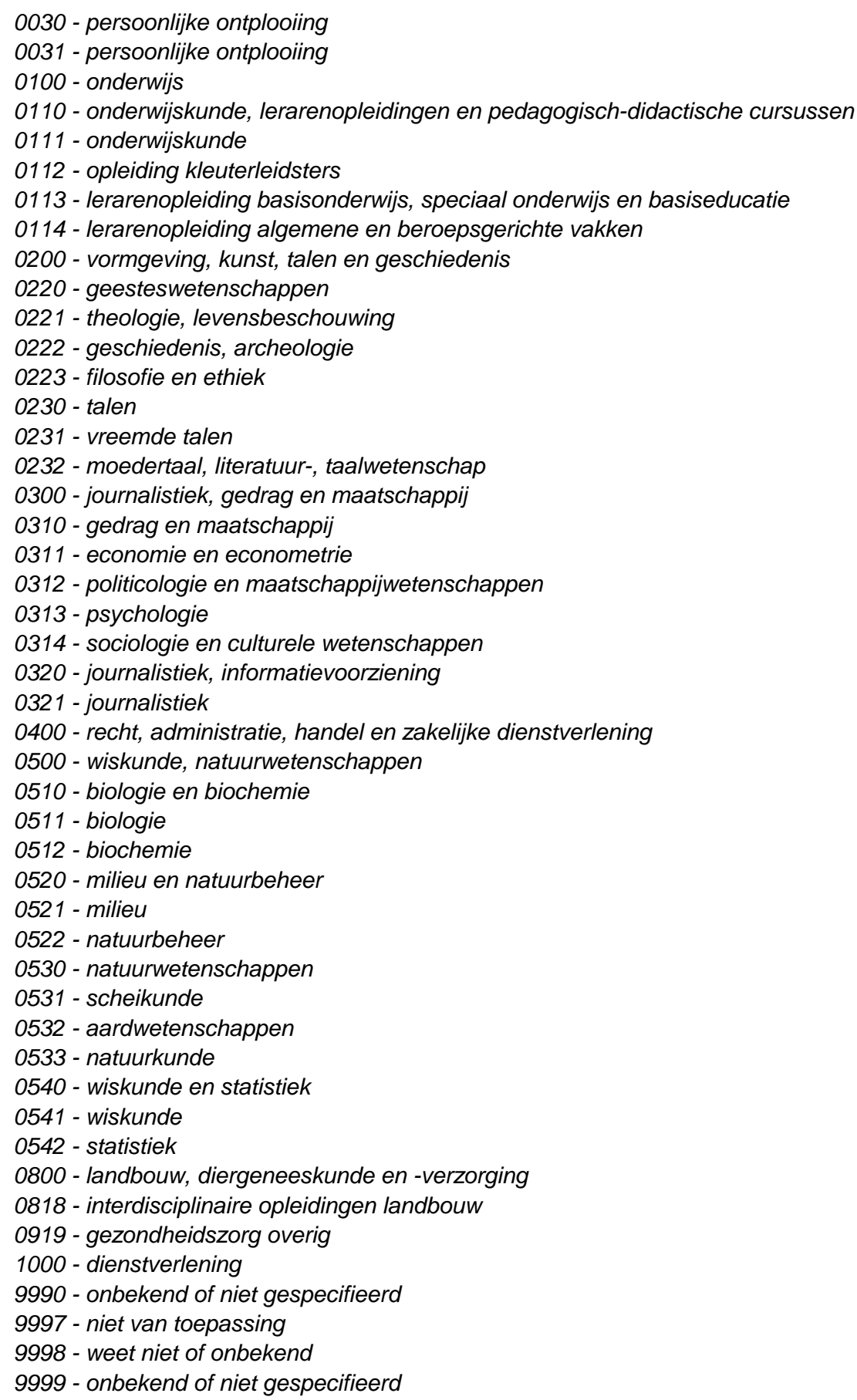

24 - Mbo4

241 - Mbo4 - economie en maatschappij

2411 - Mbo4 - economie en administratie

24111 - Mbo4 - commerciële dienstverlening

0321 - journalistiek

0414 - marketing en public relations

24112 - Mbo4 - financieel-administratieve dienstverlening

0411 - financieel management en fiscaal recht

0412 - financiële dienstverlening 


ONR2019
NIVEAU
SECTOR
$\quad \frac{\text { SUBSECTOR }}{\text { TYPE }}$
$\quad$ ISCEDF2013

24113 - Mbo4 - juridisch-administratieve dienstverlening

0420 - recht

0421 - recht

24114 - Mbo4 - secretariële en algemene administratieve dienstverlening

0322 - bibliotheek, documentaire informatievoorziening

0410 - bedrijfskunde en administratie

0413 - management bedrijfs- en personeelswetenschappen

0415 - secretariële en administratieve ondersteuning

0417 - werkgerelateerde en bedrijfsgerichte trainingen

2412 - Mbo4 - handel, ondernemerschap, transport en logistiek

24121 - Mbo4 - management en ondernemerschap

0416 - groothandel en detailhandel

24122 - Mbo4 - transport en logistiek

0830 - visserij

0831 - visserij

1040 - transport en logistiek

1041 - transport en logistiek

242 - Mbo4 - landbouw en natuur

2421 - Mbo4 - voedsel, natuur en leefomgeving

24211 - Mbo4 - landbouw en dierverzorging

0810 - landbouw

0811 - landbouw en veeteelt

24212 - Mbo4 - slagerij, bakkerij, versindustrie

0214 - kunstnijverheid

0712 - milieubescherming en milieutechnologie

0721 - levensmiddelentechnologie

24213 - Mbo4 - tuinbouw en groenvoorziening

0812 - tuinbouw

0820 - bosbouw

0821 - bosbouw

243 - Mbo4 - techniek en ict

2431 - Mbo4 - ict, media en vormgeving

24311 - Mbo4 - ict- en mediabeheer

0600 - informatica

0610 - informatica

0611 - computergebruik

0612 - ontwerp en beheer van database en netwerken

0613 - softwareontwikkeling en systeemanalyse

0619 - informatica overig

24312 - Mbo4 - mediavormgeving

0210 - kunst

0211 - audiovisuele techniek en mediaproductie

0212 - mode-, interieur- en industriële vormgeving

0213 - beeldende kunst, kunstgeschiedenis

$\underline{2432 \text { - Mbo4 - techniek, bouw en procesindustrie }}$

24321 - Mbo4 - bouw en infra

0730 - architectuur en bouwkunde

0731 - architectuur en stedebouwkunde

0732 - bouwkunde en civiele techniek

24322 - Mbo4 - elektro- en installatietechniek

0700 - techniek, industrie en bouwkunde

0710 - techniek en technische dienstverlening

0713 - elektro- en energietechniek

0714 - elektronica en industriële automatisering

24323 - Mbo4 - procestechniek en textiel

0711 - scheikundige technologie en procestechniek 


ONR2019
NIVEAU
SECTOR
$\quad \frac{\text { SUBSECTOR }}{\text { TYPE }}$
$\quad$ ISCEDF2013

0723 - textiel-, kleding-, schoenen-, en leervervaardiging

0724 - delfstofwinning

24324 - Mbo4 - werktuigbouwkunde en metaalbewerking

0715 - werktuigbouwkunde en metaalbewerking

0716 - voertuigtechniek, scheepsbouw- en vliegtuigbouwkunde

0722 - houtbewerking, papier-, kunsttofverwerking, keramiek

244 - Mbo4 - zorg en dienstverlening

2441 - Mbo4 - dienstverlening

24411 - Mbo4 - facilitaire dienstverlening

1011 - huishoudkunde, facilitiare dienstverlening en reiniging

24412 - Mbo4 - horeca

1013 - horeca

24413 - Mbo4 - schoonheids- en haarverzorging

1012 - schoonheids- en haarverzorging

24414 - Mbo4 - sport en bewegen

1014 - sport

24415 - Mbo4 - toerisme en recreatie

1015 - toerisme en vrijetijdsbesteding

2442 - Mbo4 - gezondheidszorg en welzijn

24421 - Mbo4 - laboratorium en gezondheidstechniek

0510 - biologie en biochemie

0511 - biologie

0512 - biochemie

0530 - natuurwetenschappen

0531 - scheikunde

0532 - aardwetenschappen

0533 - natuurkunde

0911 - tandheelkunde

0914 - medische diagnostiek en medische technologie

0915 - therapie en revalidatie

24422 - Mbo4 - pedagogisch werk

0110 - onderwijskunde, lerarenopleidingen en pedagogisch-didactische cursussen

0111 - onderwijskunde

0112 - opleiding kleuterleidsters

0113 - lerarenopleiding basisonderwijs, speciaal onderwijs en basiseducatie

0114 - lerarenopleiding algemene en beroepsgerichte vakken

0920 - welzijn

0921 - gehandicaptenzorg voor volwassenen en bejaarden- en gezinszorg

0922 - jeugdpedagogisch werk en kinderverzorging

24423 - Mbo4 - sociaal en maatschappelijk werk

0215 - muziek en theater

0923 - maatschappelijk werk en beroepskeuzewerk

24424 - Mbo4 - verpleegkunde en medische ondersteuning

0840 - diergeneeskunde en -verzorging

0841 - diergeneeskunde en -verzorging

0900 - gezondheidszorg en welzijn

0910 - gezondheidszorg

0912 - geneeskunde

0913 - verpleeg- en verloskunde

0916 - farmacie

0917 - traditionele en alternatieve geneeskunde en therapie

249 - Mbo4 - overig

2499 - Mbo4 - overig

24999 - Mbo4 - overig

0000 - algemeen

0010 - algemeen 


ONR2019
NIVEAU
SECTOR
$\quad \frac{\text { SUBSECTOR }}{\text { TYPE }}$
$\quad$ ISCEDF2013

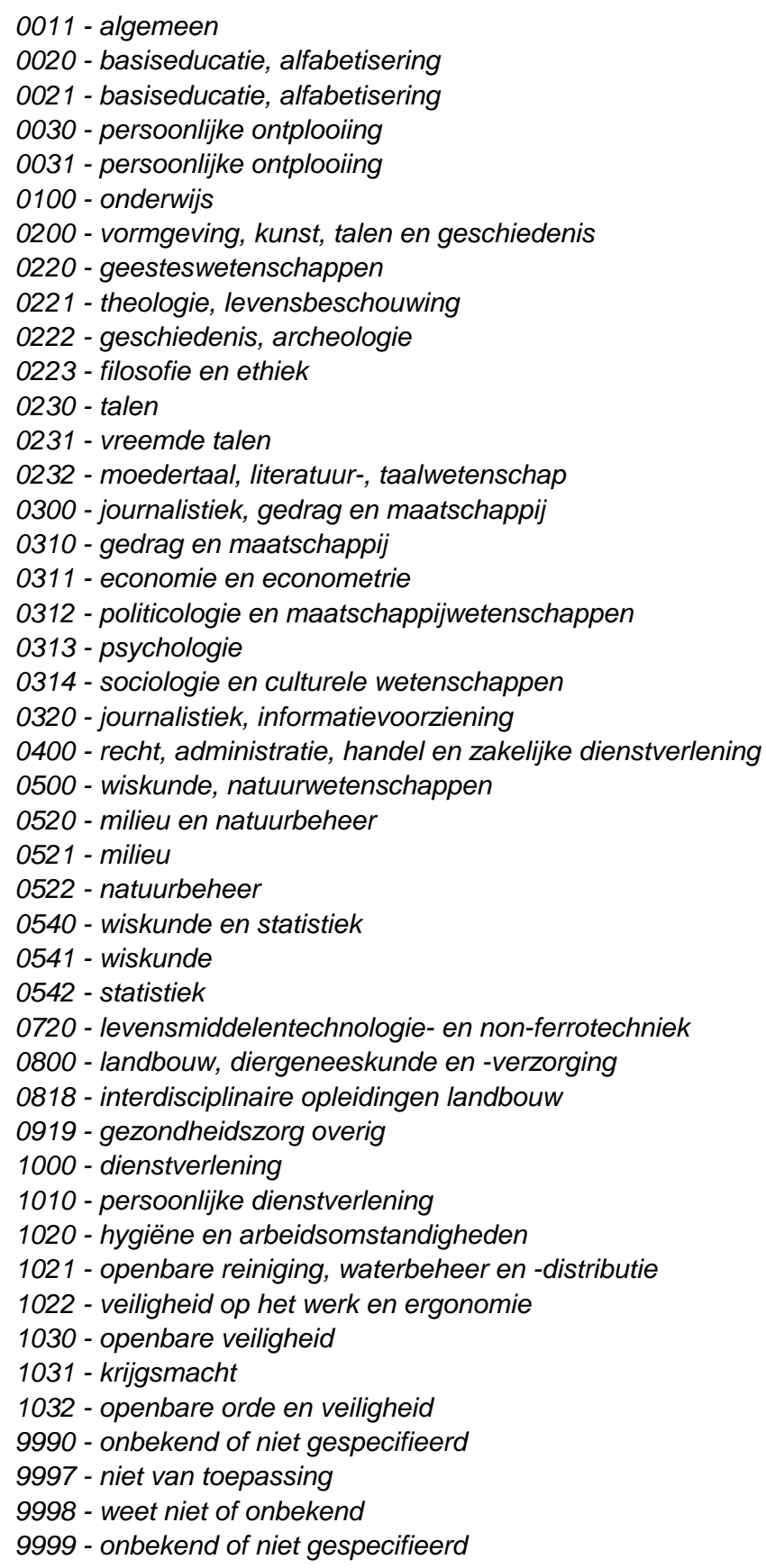




ONR2019
NIVEAU
SECTOR
$\quad \frac{\text { SUBSECTOR }}{\text { TYPE }}$
$\quad$ ISCEDF2013

1041 - transport en logistiek

3112 - Bachelor - economie en recht

31121 - Bachelor - economie en econometrie

0311 - economie en econometrie

31122 - Bachelor - financieel management en fiscaal recht

0411 - financieel management en fiscaal recht

0412 - financiële dienstverlening

0416 - groothandel en detailhandel

31123 - Bachelor - management, bedrijfs- en personeelwetenschappen

0410 - bedrijfskunde en administratie

0413 - management bedrijfs- en personeelswetenschappen

0415 - secretariële en administratieve ondersteuning

0417 - werkgerelateerde en bedrijfsgerichte trainingen

31124 - Bachelor - marketing en public relations

0414 - marketing en public relations

31125 - Bachelor - recht

0420 - recht

0421 - recht

3113 - Bachelor - journalistiek, gedrag en maatschappij

31131 - Bachelor - communicatie en journalistiek

0320 - journalistiek, informatievoorziening

0321 - journalistiek

0322 - bibliotheek, documentaire informatievoorziening

31132 - Bachelor - psychologie, sociale en maatschappijwetenschappen

0310 - gedrag en maatschappij

0312 - politicologie en maatschappijwetenschappen

0313 - psychologie

0314 - sociologie en culturele wetenschappen

3114 - Bachelor - kunst, taal en cultuur

31141 - Bachelor - kunst

0210 - kunst

0211 - audiovisuele techniek en mediaproductie

0212 - mode-, interieur- en industriële vormgeving

0213 - beeldende kunst, kunstgeschiedenis

0214 - kunstnijverheid

0215 - muziek en theater

31142 - Bachelor - taal en cultuur

0200 - vormgeving, kunst, talen en geschiedenis

0220 - geesteswetenschappen

0221 - theologie, levensbeschouwing

0222 - geschiedenis, archeologie

0223 - filosofie en ethiek

0230 - talen

0231 - vreemde talen

0232 - moedertaal, literatuur-, taalwetenschap

0721 - levensmiddelentechnologie

312 - Bachelor - landbouw en natuur

3121 - Bachelor - landbouw, wiskunde en natuurwetenschappen

31211 - Bachelor - landbouw, biologie en biochemische technologie

0510 - biologie en biochemie

0511 - biologie

0512 - biochemie

0520 - milieu en natuurbeheer

0521 - milieu

0810 - landbouw

0811 - landbouw en veeteelt 


ONR2019
NIVEAU
SECTOR
$\quad \frac{\text { SUBSECTOR }}{\text { TYPE }}$
$\quad$ ISCEDF2013

0812 - tuinbouw

0820 - bosbouw

0821 - bosbouw

0830 - visserij

0831 - visserij

31212 - Bachelor - wis-, schei-, natuurkunde en geologie

0500 - wiskunde, natuurwetenschappen

0522 - natuurbeheer

0530 - natuurwetenschappen

0531 - scheikunde

0532 - aardwetenschappen

0533 - natuurkunde

0540 - wiskunde en statistiek

0541 - wiskunde

0542 - statistiek

313 - Bachelor - techniek en ict

$\underline{3131 \text { - Bachelor - techniek en ict }}$

31311 - Bachelor - bouwkunde, civiele techniek en architectuur

0730 - architectuur en bouwkunde

0731 - architectuur en stedebouwkunde

0732 - bouwkunde en civiele techniek

31312 - Bachelor - chemische technologie

0711 - scheikundige technologie en procestechniek

0712 - milieubescherming en milieutechnologie

0720 - levensmiddelentechnologie- en non-ferrotechniek

0721 - levensmiddelentechnologie

0722 - houtbewerking, papier-, kunsttofverwerking, keramiek

0723 - textiel-, kleding-, schoenen-, en leervervaardiging

0724 - delfstofwinning

1041 - transport en logistiek

31313 - Bachelor - elektrotechniek

0713 - elektro- en energietechniek

0714 - elektronica en industriële automatisering

31314 - Bachelor - informatica

0600 - informatica

0610 - informatica

0611 - computergebruik

0612 - ontwerp en beheer van database en netwerken

0613 - softwareontwikkeling en systeemanalyse

0619 - informatica overig

31315 - Bachelor - werktuigbouwkunde

0700 - techniek, industrie en bouwkunde

0710 - techniek en technische dienstverlening

0715 - werktuigbouwkunde en metaalbewerking

0716 - voertuigtechniek, scheepsbouw- en vliegtuigbouwkunde

314 - Bachelor - zorg en onderwijs

$\underline{3141 \text { - Bachelor - gezondheidszorg en welzijn }}$

31411 - Bachelor - maatschappelijk werk

0920 - welzijn

0923 - maatschappelijk werk en beroepskeuzewerk

31412 - Bachelor - medische diagnostiek en medische technologie

0840 - diergeneeskunde en -verzorging

0841 - diergeneeskunde en -verzorging

0900 - gezondheidszorg en welzijn

0910 - gezondheidszorg

0911 - tandheelkunde 


ONR2019
NIVEAU
SECTOR
$\quad \frac{\text { SUBSECTOR }}{\text { TYPE }}$
$\quad$ ISCEDF2013

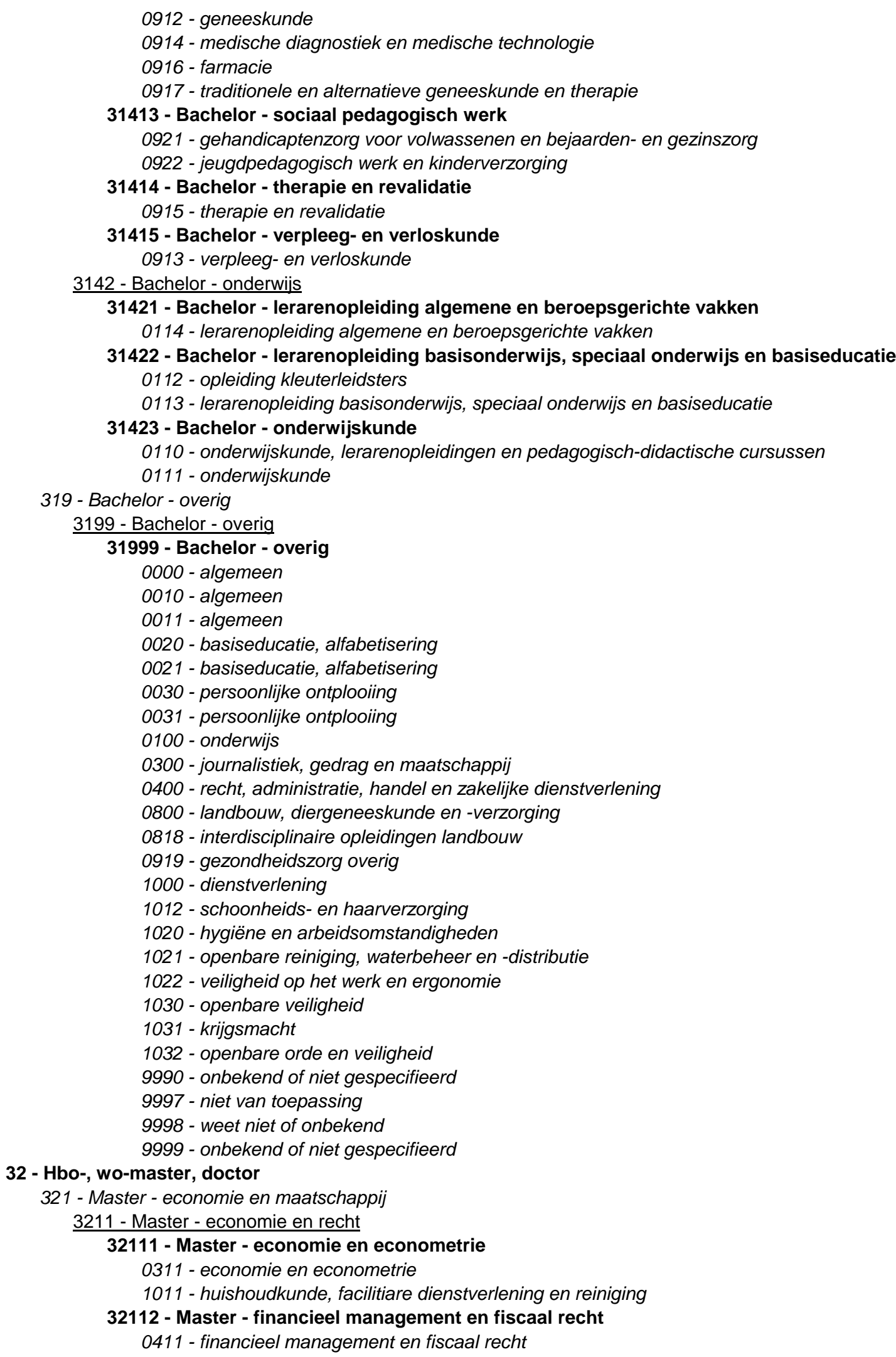




ONR2019
NIVEAU
SECTOR
$\quad \begin{aligned} & \text { SUBSECTOR } \\ & \text { TYPE } \\ & \text { ISCEDF2013 }\end{aligned}$

0412 - financiële dienstverlening

0416 - groothandel en detailhandel

32113 - Master - management, bedrijfs- en personeelwetenschappen

0410 - bedrijfskunde en administratie

0413 - management bedrijfs- en personeelswetenschappen

0415 - secretariële en administratieve ondersteuning

0417 - werkgerelateerde en bedrijfsgerichte trainingen

1040 - transport en logistiek

1041 - transport en logistiek

32114 - Master - marketing en public relations

0414 - marketing en public relations

32115 - Master - recht

0420 - recht

0421 - recht

3212 - Master - journalistiek, gedrag en maatschappii

32121 - Master - communicatie en journalistiek

0320 - journalistiek, informatievoorziening

0321 - journalistiek

0322 - bibliotheek, documentaire informatievoorziening

32122 - Master - psychologie

0310 - gedrag en maatschappij

0313 - psychologie

32123 - Master - sociale en maatschappijwetenschappen

0312 - politicologie en maatschappijwetenschappen

0314 - sociologie en culturele wetenschappen

1013 - horeca

1015 - toerisme en vrijetijdsbesteding

$\underline{3213 \text { - Master - kunst, taal en cultuur }}$

32131 - Master - kunst

0210 - kunst

0211 - audiovisuele techniek en mediaproductie

0212 - mode-, interieur- en industriële vormgeving

0213 - beeldende kunst, kunstgeschiedenis

0214 - kunstnijverheid

0215 - muziek en theater

32132 - Master - taal en cultuur

0200 - vormgeving, kunst, talen en geschiedenis

0220 - geesteswetenschappen

0221 - theologie, levensbeschouwing

0222 - geschiedenis, archeologie

0223 - filosofie en ethiek

0230 - talen

0231 - vreemde talen

0232 - moedertaal, literatuur-, taalwetenschap

322 - Master - landbouw en natuur

3221 - Master - landbouw, wiskunde en natuurwetenschappen

32211 - Master - landbouw, biologie en biochemische technologie

0510 - biologie en biochemie

0511 - biologie

0512 - biochemie

0520 - milieu en natuurbeheer

0521 - milieu

0810 - landbouw

0811 - landbouw en veeteelt

0812 - tuinbouw

0820 - bosbouw 


ONR2019
NIVEAU
SECTOR
$\quad \begin{aligned} & \text { SUBSECTOR } \\ & \text { TYPE } \\ & \text { ISCEDF2013 }\end{aligned}$

\author{
0821 - bosbouw \\ 0830 - visserij \\ 0831 - visserij
}

32212 - Master - wis-, schei-, natuurkunde en geologie

0500 - wiskunde, natuurwetenschappen

0522 - natuurbeheer

0530 - natuurwetenschappen

0531 - scheikunde

0532 - aardwetenschappen

0533 - natuurkunde

0540 - wiskunde en statistiek

0541 - wiskunde

0542 - statistiek

323 - Master - techniek en ict

3231 - Master - techniek en ict

32311 - Master - bouwkunde, civiele techniek en architectuur

0730 - architectuur en bouwkunde

0731 - architectuur en stedebouwkunde

0732 - bouwkunde en civiele techniek

32312 - Master - chemische technologie

0711 - scheikundige technologie en procestechniek

0712 - milieubescherming en milieutechnologie

0720 - levensmiddelentechnologie- en non-ferrotechniek

0721 - levensmiddelentechnologie

0722 - houtbewerking, papier-, kunsttofverwerking, keramiek

0723 - textiel-, kleding-, schoenen-, en leervervaardiging

0724 - delfstofwinning

32313 - Master - elektrotechniek

0713 - elektro- en energietechniek

0714 - elektronica en industriële automatisering

32314 - Master - informatica

0600 - informatica

0610 - informatica

0611 - computergebruik

0612 - ontwerp en beheer van database en netwerken

0613 - softwareontwikkeling en systeemanalyse

0619 - informatica overig

32315 - Master - werktuigbouwkunde

0700 - techniek, industrie en bouwkunde

0710 - techniek en technische dienstverlening

0715 - werktuigbouwkunde en metaalbewerking

0716 - voertuigtechniek, scheepsbouw- en vliegtuigbouwkunde

324 - Master - zorg en onderwijs

$\underline{3241 \text { - Master - gezondheidszorg }}$

32411 - Master - (dier)geneeskunde en tandheelkunde

0840 - diergeneeskunde en -verzorging

0841 - diergeneeskunde en -verzorging

0911 - tandheelkunde

0912 - geneeskunde

32412 - Master - farmacie en gezondsheidswetenschappen

0900 - gezondheidszorg en welzijn

0910 - gezondheidszorg

0913 - verpleeg- en verloskunde

0914 - medische diagnostiek en medische technologie

0915 - therapie en revalidatie

0916 - farmacie 


ONR2019
NIVEAU
SECTOR
$\quad \begin{aligned} & \text { SUBSECTOR } \\ & \text { TYPE } \\ & \text { ISCEDF2013 }\end{aligned}$

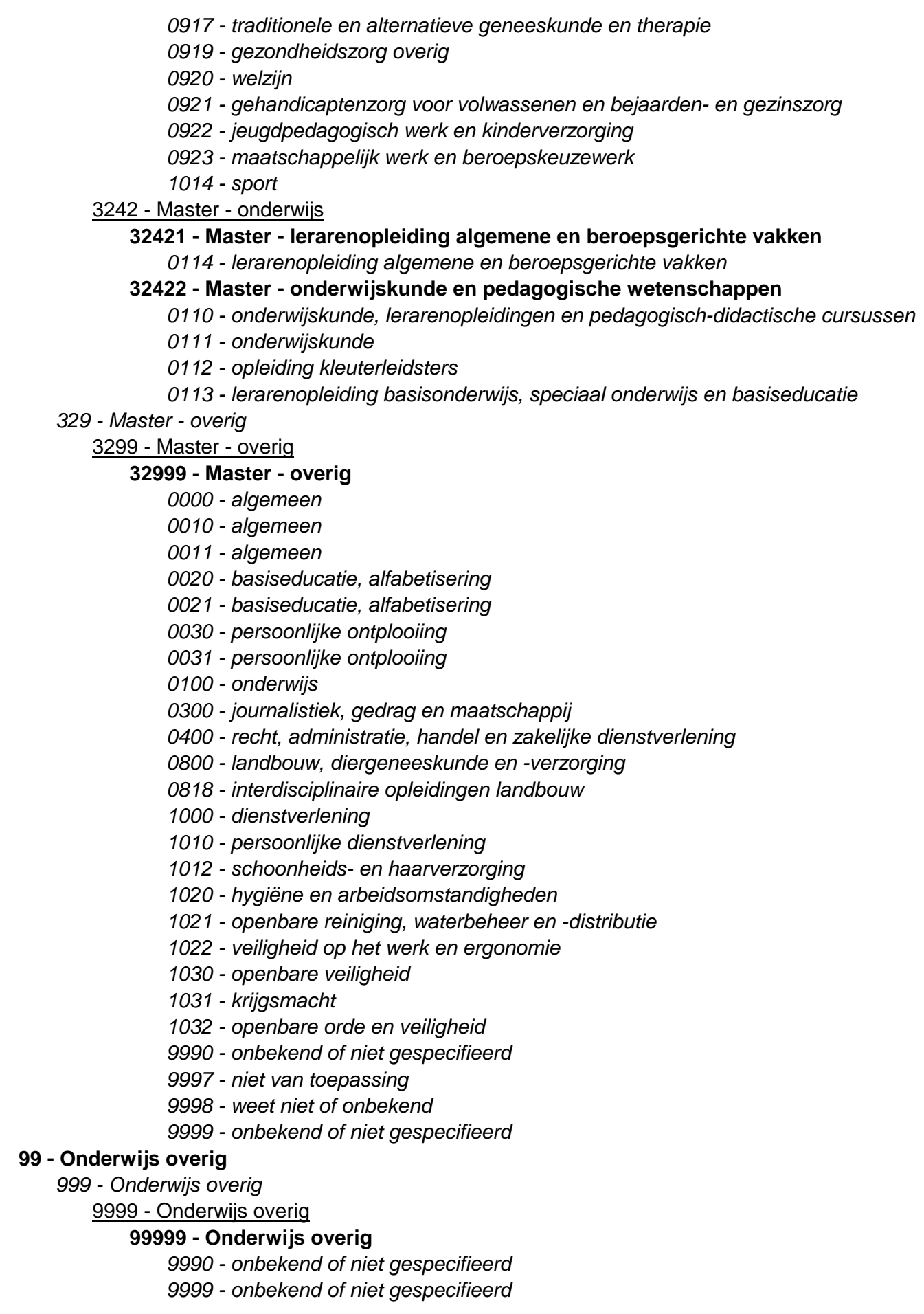




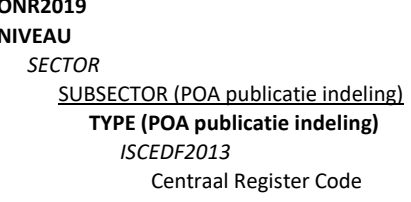


94500 - signmaker (medewerker sign )

25202 - medewerker podium- en evenemententechniek

95712 - podium- en evenemententechniek (medewerker podium- en evenemententechniek)

25217 - stand- en decorbouwer

95707 - dtp-er (medewerker dtp goc)

90052 - av-productie (medewerker fotografie savantis)

25207 - basismedewerker printmedia

95708 - dtp-er (medewerker dtp savantis)

90053 - av-productie (medewerker fotografie vapro)

0212 - mode-, interieur- en industriële vormgeving

25211 - medewerker productpresentatie

91530 - vormgeving ruimtelijke presentatie en communicatie (medewerker productpresentatie)

0613 - softwareontwikkeling en systeemanalyse

25192 - medewerker ict

95060 - ict-medewerker (medewerker ict)

0711 - scheikundige technologie en procestechniek

90311 - operator (operator a)

25337 - procesoperator a

90312 - operator (operator productietechniek)

25010 - industrieel lakverwerker

92715 - medewerker industri+le lakverwerking (lakspuiter)

92711 - medewerker industri+le lakverwerking (jachtschilder)

0713 - elektro- en energietechniek

25333 - monteur elektrotechnische installaties

25350 - monteur werktuigkundige installaties

94272 - installeren (monteur werktuigkundige installaties)

25273 - monteur laagspanningsdistributie

92113 - infratechniek (monteur gas/water/warmte kenteq)

25308 - monteur service en onderhoud installaties en systemen

25272 - monteur gas-, water- en warmtedistributie

25341 - monteur elektrotechnische systemen

92111 - infratechniek (monteur data/elektra kenteq)

92390 - elektrotechnische industri+le producten en systemen (monteur)

94274 - installeren (monteur koudetechniek)

25282 - monteur koude- en klimaatsystemen

95472 - service apparatuur en installaties (onderhoudsmonteur installatietechniek)

25274 - monteur middenspanningsdistributie

0714 - elektronica en industriële automatisering

94271 - installeren (monteur elektrotechnische installaties)

25342 - monteur mechatronica

91080 - machinebouw mechatronica (monteur mechatronica)

0715 - werktuigbouwkunde en metaalbewerking

25291 - constructiewerker

95761 - metaalbewerken (constructiewerker)

25302 - verspaner

25231 - fietstechnicus

25335 - mechanisch operator a

25290 - basislasser

94340 - fijnmechanische techniek (verspaner)

90872 - tweewielertechniek (fietstechnicus)

25235 - scootertechnicus

25293 - plaatwerker

90871 - tweewielertechniek (scootertechnicus)

25334 - medewerker operationele techniek

25292 - pijpenbewerker

95690 - metaalbewerken (plaatwerker)

94302 - metaalbewerken (basislasser)

95471 - service apparatuur en installaties (onderhoudsmonteur industrie)

91690 - medewerker operationele techniek (medewerker operationele techniek)

0716 - voertuigtechniek, scheepsbouw- en vliegtuigbouwkunde

25242 - autotechnicus

93410 - autotechniek (autotechnicus)

25243 - bedrijfsautotechnicus

25246 - monteur mobiele werktuigen

93440 - bedrijfsautotechniek (bedrijfsautotechnicus)

25225 - autoschadehersteller

25234 - motorfietstechnicus

25228 - autospuiter

91770 - autospuiter (autospuiter niveau 2)

92141 - mobiele werktuigen (monteur mobiele werktuigen kenteq)

25220 - assemblagetechnicus

95030 - autoschadehersteltechniek (autoschadehersteller niveau 2)

93470 - motorfietstechniek (motorfietstechnicus)

25222 - carrosseriebouwer

25319 - samenbouwer vliegtuigbouw

93142 - verbrandingsmotortechniek (verbrandingsmotortechnicus)

91790 - carrosseriebouwer (carrosseriebouwer niveau 2) 
25295 - scheepsmetaalbewerker

92142 - mobiele werktuigen (monteur mobiele werktuigen fundeon)

94374 - vliegtuigbouw (samenbouwer)

92230 - assemblagetechnicus mobiliteitsbranche

0722 - houtbewerking, papier-, kunsttofverwerking, keramiek

25008 - montagemedewerker industrieel produceren met hout

25016 - machinaal houtbewerker

95000 - machinaal houtbewerker

94610 - montagemedewerker timmerindustrie

0723 - textiel-, kleding-, schoenen-, en leervervaardiging

25159 - basismedewerker mode

25022 - meubelstoffeerder

91240 - medewerker mode/maatkleding (basismedewerker mode/maatkleding)

25062 - schoenhersteller 2

93560 - meubelstoffeerder

0732 - bouwkunde en civiele techniek

25128 - timmerman

94920 - timmerman

25018 - meubelmaker/(scheeps)interieurbouwer

25030 - schilder

25024 - servicemedewerker gebouwen

94570 - meubelmaker/(scheeps)interieurbouwer (meubelmaker/(scheeps)interieurbouwer)

91450 - medewerker schilderen (schilder)

25088 - dakdekker bitumen en kunststof

25038 - stukadoor

25097 - vakman gww

25103 - metselaar

93980 - vakman gww

25117 - tegelzetter

94000 - straatmaker (opperman bestratingen)

92180 - onderhoud- en verbouwbedrijf (servicemedewerker gebouwen)

93843 - dakdekker (dakdekker metaal)

25095 - opperman bestratingen

93901 - metselaar (metselaar inclusief casco lijmwerk)

93600 - medewerker stukadoren (stukadoor)

94020 - waterbouwer

93902 - metselaar (metselaar inclusief lichte scheidingswanden)

93931 - betonreparateur (fundeon)

90960 - woningstoffeerder (basis woningstoffeerder)

25040 - woning-/projectstoffeerder

93540 - parketteur

93910 - tegelzetter

25006 - glaszetter

25027 - plafond- en wandmonteur

92042 - natuursteenbewerker (natuursteenbewerker grafwerk)

25111 - natuursteenbewerker machinaal

25115 - sloper

25113 - natuursteenbewerker ambachtelijk

25093 - asfaltafwerker

25080 - betonreparateur

25543 - Monteur metalen daken en gevels

93846 - dakdekker (dakdekker pannen/leien)

93960 - vakman asfalt (asfaltafwerker)

92043 - natuursteenbewerker (natuursteenbewerker machinaal)

25003 - dekvloerenlegger

25098 - waterbouwer

93820 - steigerbouwer

93310 - betontimmerman (betontimmerman primair)

95682 - sloper (sloper)

224 - Mbo2 - zorg en dienstverlening

2240 - Mbo2 - zorg en dienstverlenin

22400 - Mbo2 - zorg en dienstverlening

0911 - tandheelkunde

95221 - tandtechniek (tandtechnisch medewerker basistechnieken)

921 - gehandicaptenzorg voor volwassenen en bejaarden- en gezinszorg

26007 - servicemedewerker

95751 - facilitaire dienstverlener (facilitair medewerker)

25034 - schoonmaker in verschillende omgevingen

1012 - schoonheids- en haarverzorging

25400 - kapper

95120 - kapper (junior kapper)

1013 - horeca

25180 - kok 
25168 - gastheer/-vrouw

25178 - medewerker fastservice

90760 - kok

94140 - medewerker bediening/caf+-bar (gastheer/-vrouw)

94190 - fastservice (medewerker fastservice)

1014 - sport

25500 - medewerker sport en recreatie

95300 - sport- en bewegingsbegeleider

1015 - toerisme en vrijetijdsbesteding

25453 - medewerker natuur, water en recreatie

94110 - leisure \& hospitality (leisure \& hospitality assistant)

97532 - natuur en groene ruimte 2 (medewerker recreatiebedrijf)

25356 - medewerker watersportindustrie

94960 - watersportindustrie (medewerker watersportindustrie)

1021 - openbare reiniging, waterbeheer en -distributie

25001 - allround medewerker afvalbeheer

25002 - allround medewerker beheer openbare ruimte

1031 - krijgsmacht

25416 - aankomend medewerker grondoptreden

25417 - aankomend medewerker maritiem

95082 - veiligheid en vakmanschap (aankomend medewerker maritiem)

95081 - veiligheid en vakmanschap (aankomend medewerker grondoptreden)

1032 - openbare orde en veiligheid

25407 - beveiliger

94850 - particuliere beveiliging (beveiliger)

25410 - medewerker toezicht en veiligheid

93280 - toezicht en veiligheid (medewerker toezicht en veiligheid)

23 - Mbo3

231 - Mbo3 - economie en maatschappij

2311 - Mbo3 - economie en administratie

\section{1 - Mbo3 - financieel-administratieve dienstverlening}

0411 - financieel management en fiscaal recht

93200 - financi+le beroepen (financieel administratief medewerker)

25139 - financieel administratief medewerker

23112 - Mbo3 - secretariële dienstverlening

0415 - secretariële en administratieve ondersteuning

90622 - front officemedewerker (receptionist)

25152 - secretaresse

95380 - secretari+le beroepen (secretaresse)

90621 - front officemedewerker (informatiemedewerker)

2312 - Mbo3 - handel, ondernemerschap, transport en logistiek

23121 - Mbo3 - detailhandel en groothandel

0416 - groothandel en detailhandel

25155 - verkoopspecialist

90383 - verkoopspecialist (verkoopspecialist detailhandel)

25134 - commercieel medewerker

25153 - eerste verkoper

90112 - commercieel medewerker (commercieel medewerker binnendienst kc handel)

97430 - bloemendetailhandel (vakbekwaam medewerker bloembinden)

25425 - vakbekwaam medewerker vers

90384 - verkoopspecialist (eerste verkoper)

90111 - commercieel medewerker (commercieel medewerker binnendienst ecabo)

25135 - contactcenter medewerker

90381 - verkoopspecialist (verkoopadviseur wonen)

25239 - verkoopadviseur mobiliteitsbranche

97750 - logistiek vakman (vakbekwaam medewerker vershandel, logistiek en transport)

90113 - commercieel medewerker (commercieel medewerker buitendienst)

97791 - gezelschapsdierenbranche (vakbekwaam verkoper gezelschapsdieren)

97794 - groene detailhandel (vakbekwaam medewerker groene detailhandel)

95450 - verkoopadviseur mobiliteitsbranche

25434 - vakbekwaam medewerker agrohandel en logistiek

25501 - verkoopspecialist groene detailhandel

25073 - medewerker juwelier

25154 - verkoopadviseur

91634 - vakbekwaam medewerker versdetailhandel (visspecialist)

90385 - verkoopspecialist (verkoopspecialist mode)

92810 - juweliersbedrijf (medewerker juwelier)

23122 - Mbo3 - transport en logistiek

0831 - visserij

95738 - visserij officier (stuurman-scheepswerktuigkundige vissersschepen sw5)

1041 - transport en logistiek

25372 - logistiek teamleide

95630 - binnenvaart (schipper binnenvaart)

90201 - logistiek teamleider (logistiek teamleider kc handel)

90202 - logistiek groepsleider (logistiek groepsleider vtl)

25384 - machinist railvervoer

95733 - koopvaardij officier kleine schepen (stuurman-werktuigkundige kleine schepen)

710

270

240

80

20
190

1.110

80

70 
25397 - gevorderd medewerker havenoperaties

25393 - co:rdinator havenlogistiek

25389 - planner wegtransport

93030 - bootman

95250 - havenlogistiek (co@rdinator havenlogistiek)

95732 - koopvaardij officier kleine schepen (stuurman kleine schepen)

25383 - touringcarchauffeur/reisleider

25514 - Stuurman kleine schepen

25515 - Scheepswerktuigkundige kleine schepen

95731 - koopvaardij officier kleine schepen (scheepswerktuigkundige kleine schepen )

95724 - chauffeur personenvervoer (touringcarchauffeur / reisleider)

95650 - machinist railvervoer (machinist railvervoer)

25513 - Stuurman-werktuigkundige kleine schepen

91890 - planner wegtransport

232 - Mbo3 - landbouw en natuur

2321 - Mbo3 - voedsel, natuur en leefomgeving

23211 - Mbo3 - landbouw en dierverzorging

0811 - landbouw en veeteelt

97720 - recreatiedieren (dierverzorger recreatiedieren)

97703 - productiedieren (dierverzorger melkvee)

97150 - groen, grond, infra (vakbekwaam medewerker gemechaniseerd loonbedrijf)

97670 - teelt 2/3 (vakbekwaam medewerker teelt)

25536 - Vakbekwaam medewerker teelt

97551 - zorg, natuur en gezondheid (werkbegeleider zorgbedrijf dier)

97702 - productiedieren (dierverzorger hokdieren)

97460 - gespecialiseerde dierverzorging gezelschapsdieren (trimmer)

25450 - vakbekwaam medewerker dierverzorging

97510 - gespecialiseerde dierverzorging paard (hoefsmid)

97770 - proefdieren (proefdierverzorger aequor)

25433 - vakbekwaam medewerker agrarisch loonwerk

97130 - biologisch-dynamisch bedrijf (vakbekwaam medewerker biologisch-dynamisch bedrijf)

25470 - vakbekwaam medewerker paardensport en -houderij

97552 - zorg, natuur en gezondheid (werkbegeleider zorgbedrijf plant)

25435 - vakbekwaam medewerker teelt

25537 - Vakbekwaam medewerker veehouderij

25541 - Vakbekwaam medewerker dierverzorging

23212 - Mbo3 - slagerij, bakkerij, versindustrie

0214 - kunstnijverheid

25444 - vakbekwaam medewerker bloem, groen en styling

92871 - pianotechniek (pianotechnicus)

92872 - pianotechniek (pianotechnicus/ondernemer)

0721 - levensmiddelentechnologie

95748 - brood en banket (zelfstandig werkend banketbakker)

95749 - brood en banket (zelfstandig werkend broodbakker)

97340 - allround operator (allround voedingsoperator aequor)

25174 - zelfstandig werkend bakker

25427 - allround medewerker versindustrie

25461 - vakbekwaam medewerker voeding en technologie

94760 - leidinggevende versindustrie (meewerkend voorman versindustrie)

94730 - productievakkracht versindustrie

90014 - allround operator (allround operator voedingsindustrie)

23213 - Mbo3 - tuinbouw en groenvoorziening

0712 - milieubescherming en milieutechnologie

97254 - natuur en groene ruimte 3 (vakbekwaam medewerker land, water en milieu)

0812 - tuinbouw

97253 - natuur en groene ruimte 3 (vakbekwaam hovenier)

25455 - vakbekwaam hovenier

97252 - natuur en groene ruimte 3 (vakbekwaam medewerker groenvoorziening)

25456 - vakbekwaam medewerker groen en cultuurtechniek

0821 - bosbouw

97251 - natuur en groene ruimte 3 (vakbekwaam medewerker bos en natuurbeheer)

233 - Mbo3 - techniek en ict

2331 - Mbo3 - ict, media en vormgeving

23311 - Mbo3 - ict-ondersteuning

0612 - ontwerp en beheer van database en netwerken

25191 - medewerker beheer ict

95070 - ict-medewerker (medewerker beheer ict)

23312 - Mbo3 - mediatechniek

0211 - audiovisuele techniek en mediaproductie

95705 - dtp-er (allround dtp-er goc)

95713 - podium- en evenemententechniek (podium- en evenemententechnicus)

94510 - signmaker (allround signmaker)

25197 - allround dtp-er

25203 - podium- en evenemententechnicus

90061 - av-productie (allround av-medewerker kc goc)

95706 - dtp-er (allround dtp-er savantis)

25213 - allround signmaker 
90062 - av-productie (allround av-medewerker savantis)

95718 - printmedia (digitaal drukker)

25208 - drukker

25216 - allround stand- en decorbouwer

90063 - av-productie (allround av-medewerker vapro)

0212 - mode-, interieur- en industriële vormgeving

97480 - natuur en vormgeving (vakbekwaam medewerker natuur en vormgeving)

2332 - Mbo3 - techniek, bouw en procesindustrie

23321 - Mbo3 - bouw en infra

0732 - bouwkunde en civiele techniek

95580 - meubelmaker/(scheeps)interieurbouwer (allround meubelmaker/(scheeps)interieurbouwer)

94932 - timmerman (allround timmerman nieuwbouw)

25118 - allround timmerman

93183 - machinist (machinist grondverzet)

94931 - timmerman (allround timmerman bouw- en werkplaats)

91461 - medewerker schilderen (gezel schilder voorman)

95272 - onderhoud- en verbouwbedrijf (allround ondernemer klussenbedrijf)

25029 - gezel schilder

95684 - medewerker schilderen (gezel schilder)

25023 - allround vakkracht onderhoud- en klussenbedrijf

25017 - allround meubelmaker/(scheeps)interieurbouwe

91501 - medewerker stukadoren (gezel stukadoor decoratie)

25099 - machinist grondverzet

25086 - allround dakdekker bitumen en kunststof

94010 - straatmaker

94933 - timmerman (allround timmerman restauratie)

93990 - vakman gww (allround vakman gww)

25102 - allround metselaar

93941 - betonreparateur (allround betonreparateur fundeon)

25037 - gezel stukadoor

93830 - steigerbouwer (allround steigerbouwer)

93853 - dakdekker (allround dakdekker bitumen en kunststof)

94822 - metselaar (allround metselaar herstel en restauratie)

93320 - betontimmerman (betontimmerman voortgezet)

25091 - allround vakman gww

93186 - machinist (machinist wegenbouw)

25039 - allround woningstoffeerder

90970 - woningstoffeerder (allround woningstoffeerder)

26001 - technicus hout en restauratie

25096 - straatmaker

94823 - metselaar (allround metselaar aan- en verbouw)

25005 - gezel glaszetter

94031 - waterbouwer (allround waterbouwer)

93920 - tegelzetter (allround tegelzetter)

25109 - allround natuursteenbewerker

93550 - parketteur (allround parketteur)

25542 - Allround dakdekker metaal

25116 - allround tegelzetter

95680 - natuursteenbewerker (allround natuursteenbewerker)

25025 - allround parketteur

93854 - dakdekker (allround dakdekker metaal)

94283 - installeren (eerste monteur dak)

91502 - medewerker stukadoren (gezel stukadoor voorman)

94821 - metselaar (allround metselaar inclusief nieuwe metseltechnieken)

23322 - Mbo3 - elektro- en installatietechniek

0713 - elektro- en energietechniek

94282 - installeren (eerste monteur werktuigkundige installaties)

25332 - eerste monteur elektrotechnische installaties woning en utiliteit

92400 - elektrotechnische industri+le producten en systemen (eerste monteur)

25349 - eerste monteur woning

94323 - service apparatuur en installaties (servicemonteur installatietechniek)

92121 - infratechniek (eerste monteur data/elektra kenteq)

92122 - infratechniek (eerste monteur gas/water/warmte kenteq)

25269 - eerste monteur laagspanningsdistributie

25331 - eerste monteur elektrotechnische industriÙle installaties en systemen

94321 - service apparatuur en installaties (servicemonteur elektrotechniek)

25270 - eerste monteur middenspanningsdistributie

25307 - eerste monteur service en onderhoud werktuigkundige installaties

25304 - eerste monteur service en onderhoud elektrotechniek en instrumentatie

25339 - eerste monteur elektrotechnische systemen

25267 - eerste monteur gas-, water- en warmtedistributie

92123 - infratechniek (eerste monteur gas/water/warmte fundeon)

25284 - servicemonteur koude- en klimaatsystemen

25348 - eerste monteur utiliteit

25281 - eerste monteur koude- en klimaatsystemen

25562 - servicemonteur koude- en klimaatsystemen

25316 - tekenaar werktuigkundige installaties 
94322 - service apparatuur en installaties (inspectiemonteur koudetechniek) 0

0714 - elektronica en industriële automatisering 610

94281 - installeren (eerste monteur elektrotechnische installaties) 610

23323 - Mbo3 - procestechniek en textie

0711 - scheikundige technologie en procestechniek

90012 - allround operator (operator b)

91730 - laboratoriummedewerker (allround laborant)

25338 - procesoperator b

25044 - allround laborant

92724 - medewerker industri+le lakverwerking (vakkracht lakspuiter)

92721 - medewerker industri+le lakverwerking (vakkracht jachtschilder)

90011 - allround operator (allround operator productietechniek)

25011 - vakkracht industrieel lakverwerker

0723 - textiel-, kleding-, schoenen-, en leervervaardiging

91250 - medewerker mode/maatkleding (allround medewerker mode/maatkleding )

93570 - meubelstoffeerder (allround meubelstoffeerder)

95694 - orthopedische technieken (leestenmaker)

95590 - schoenhersteller (schoenhersteller/ondernemer)

25163 - allround medewerker mode/maatkleding

25021 - allround meubelstoffeerder

23324 - Mbo3 - werktuigbouwkunde en metaalbewerking

0715 - werktuigbouwkunde en metaalbewerking

94312 - metaalbewerken (allround constructiewerker)

91091 - machinebouw mechatronica (machinebouwer)

25286 - allround constructiewerker

94351 - fijnmechanische techniek (allround verspaner)

25340 - eerste monteur mechatronica

25336 - mechanisch operator $b$

25298 - allround verspaner

91670 - operationele techniek (operationeel technicus)

94324 - service apparatuur en installaties (servicemonteur werktuigbouw)

91092 - machinebouw mechatronica (monteur tester mechatronica)

25306 - eerste monteur service en onderhoud werktuigbouw

95442 - tweewielertechniek (eerste fietstechnicus)

94314 - metaalbewerken (allround plaatwerker)

94311 - metaalbewerken (allround lasser)

92790 - goud- en zilversmeden (basisgoudsmid)

25299 - gereedschapsmaker

25288 - allround pijpenbewerker

94352 - fijnmechanische techniek (fijnmechanisch verspaner)

25230 - eerste fietstechnicus

93184 - machinist (machinist hijswerk fundeon)

92500 - werkvoorbereiden (technisch tekenaar)

25289 - allround plaatwerker

95200 - uurwerktechniek (medewerker uurwerktechniek)

95441 - tweewielertechniek (eerste scootertechnicus)

25233 - eerste scootertechnicus

25287 - allround lasser

25100 - machinist hijswerk

0716 - voertuigtechniek, scheepsbouw- en vliegtuigbouwkunde

93420 - autotechniek (eerste autotechnicus)

93450 - bedrijfsautotechniek (eerste bedrijfsautotechnicus)

92151 - mobiele werktuigen (allround monteur mobiele werktuigen kenteq)

1.070

940

520

230

100

244 - eerste autotechnicus

95762 - vliegtuigonderhoud (eerste monteur)

92152 - mobiele werktuigen (allround monteur mobiele werktuigen fundeon)

25245 - eerste bedrijfsautotechnicus

91780 - autospuiter (autospuiter niveau 3)

95041 - autoschadehersteltechniek (autoschadehersteller niveau 3)

25229 - eerste autospuiter

25227 - eerste autoschadetechnicus

25321 - eerste monteur vliegtuigonderhoud

90900 - eerste verbrandingsmotortechnicus

25226 - eerste autoschadehersteller

25232 - eerste motorfietstechnicus

25219 - serviceadviseur mobiliteitsbranche

91800 - carrosseriebouwer (carrosseriebouwer niveau 3)

93480 - motorfietstechniek (eerste motorfietstechnicus)

25294 - scheepsbouwer

93390 - serviceadviseur mobiliteitsbranche

95042 - autoschadehersteltechniek (autoschadetechnicus niveau 3)

25236 - eerste verbrandingsmotortechnicus

0722 - houtbewerking, papier-, kunsttofverwerking, keramiek

95570 - machinaal houtbewerker (allround machinaal houtbewerker)

94621 - montagemedewerker timmerindustrie (allround montagemedewerker gevelelementen)

94622 - montagemedewerker timmerindustrie (allround houtskeletbouwer)

25015 - allround machinaal houtbewerker 
SUBSECTOR (POA publicatie indeling)

TYPE (POA publicatie indeling)

ISCEDF2013

Centraal Register Code

25007 - allround montagemedewerker industrieel produceren met hout

1013 - horeca

95420 - kok (zelfstandig werkend kok)

94153 - medewerker bediening/caf+-bar (zelfstandig werkend gastheer/-vrouw)

25182 - zelfstandig werkend kok

25176 - 1e medewerker fastservice

25171 - zelfstandig werkend gastheer/-vrouw

94200 - fastservice (1e medewerker fastservice)

23412 - Mbo3 - reiniging, sport en toerisme

1014 - sport

95280 - sport en bewegen (sport- en bewegingsleider)

25415 - sport- en bewegingsleider

97230 - paardensport (instructeur paardensport iii)

91390 - sport en bewegen (sport en bewegingsleider)

1015 - toerisme en vrijetijdsbesteding

94120 - leisure \& hospitality (leisure \& hospitality host)

94090 - reizen (verkoper reizen)

25353 - zelfstandig medewerker leisure \& hospitality

25354 - zelfstandig medewerker travel \& hospitality

97255 - natuur en groene ruimte 3 (vakbekwaam medewerker recreatiebedrijf)

25457 - vakbekwaam medewerker natuur, water en recreatie

93370 - watersportindustrie (allround medewerker watersportindustrie)

25355 - allround medewerker watersportindustrie

23413 - Mbo3 - schoonheids- en haarverzorging

1012 - schoonheids- en haarverzorging

91182 - kapper

25404 - schoonheidsspecialist

95746 - schoonheidsspecialist

25399 - allround kapper

95744 - pedicure

25406 - pedicure

23414 - Mbo3 - veiligheid

1031 - krijgsmacht

95091 - veiligheid en vakmanschap (aankomend onderofficier grondoptreden)

95092 - veiligheid en vakmanschap (aankomend onderofficier maritiem)

1032 - openbare orde en veiligheid

25409 - handhaver toezicht en veiligheid

94810 - toezicht en veiligheid (handhaver toezicht en veiligheid)

90550 - beveiliger (co+rdinator beveiliging)

25408 - co $\div$ rdinator beveiliging

$\underline{2342-M b o 3-\text { gezondheidszorg en welzijn }}$

23421 - Mbo3 - laboratorium en gezondheidstechniek

0914 - medische diagnostiek en medische technologie

95010 - medewerker steriele medische hulpmiddelen

93640 - optiek (allround medewerker optiek)

25053 - medewerker steriele medische hulpmiddelen

23422 - Mbo3 - verzorgende ig

0921 - gehandicaptenzorg voor volwassenen en bejaarden- en gezinszorg

95530 - verzorgende-ig

92650 - maatschappelijke zorg (medewerker maatschappelijke zorg)

92620 - pedagogisch werk (pedagogisch medewerker 3 kinderopvang )

25491 - verzorgende ig

25475 - begeleider gehandicaptenzorg

0922 - jeugdpedagogisch werk en kinderverzorging

25486 - pedagogisch medewerker kinderopvan

0923 - maatschappelijk werk en beroepskeuzewerk

25476 - begeleider specifieke doelgroepen

90532 - medewerker marketing en communicatie (marketing medewerker)

93802 - commercieel medewerker ((junior) accountmanager kc handel)

93801 - commercieel medewerker ((junior) accountmanager ecabo)

25148 - medewerker marketing en communicatie

25132 - (junior) accountmanager

25527 - Junior productmanager fashion

24112 - Mbo4 - financieel-administratieve dienstverlening

0411 - financieel management en fiscaal recht

93212 - financi+le beroepen (bedrijfsadministrateur) 
93211 - financi+le beroepen (assistent-accountant)

25138 - bedrijfsadministrateur

25140 - junior assistent-accountant

93213 - financi+le beroepen (salarisadministrateur)

0412 - financiële dienstverlening

90500 - commercieel medewerker bank- en verzekeringswezen

94910 - medewerker sociale zekerheid

25544 - klantmedewerker bancaire diensten

24113 - Mbo4 - juridisch-administratieve dienstverlening

0421 - recht

94891 - juridisch medewerker (juridisch medewerker zakelijke dienstverlening)

24114 - Mbo4 - secretariële en algemene administratieve dienstverlening

0322 - bibliotheek, documentaire informatievoorziening

25131 - bibliotheekmedewerker

95693 - behoudsmedewerker (behoudsmedewerker)

90522 - medewerker informatiedienstverlening (bibliotheekmedewerker)

0413 - management bedrijfs- en personeelswetenschappen

95391 - secretari+le beroepen (directiesecretaresse/managementassistent)

94072 - frontofficemedewerker (frontofficemanager)

94892 - juridisch medewerker (juridisch medewerker openbaar bestuur)

25145 - juridisch-administratief dienstverlener

94900 - medewerker personeel en arbeid

25160 - leidinggevende team/afdeling/project

25199 - mediamanager

25161 - technisch leidinggevende

95400 - mediamanagement (mediamanager)

25151 - managementassistent/directiesecretaresse

94071 - frontofficemedewerker (hoofd informatie)

25165 - vakman-ondernemer

25146 - medewerker human resource management ( $\mathrm{hrm})$

25529 - Technisch Leidinggevende

0415 - secretariële en administratieve ondersteuning

95392 - secretari+le beroepen (juridisch secretaresse)

95393 - secretaritle beroepen (medisch secretaresse)

2412 - Mbo4 - handel, ondernemerschap, transport en logistiek

24121 - Mbo4 - management en ondernemerschap

0416 - groothandel en detailhandel

93492 - manager handel (filiaalmanager)

93494 - manager handel (vestigingsmanager groothandel)

90290 - ondernemer detailhandel

25162 - manager retail

90933 - assistent-manager internationale handel (assistent-manager internationale handel binnendienst)

97792 - groene detailhandel (manager groene detailhandel)

90932 - assistent-manager internationale handel (assistent-manager internationale handel buitendienst)

93491 - manager handel (afdelingsmanager)

97761 - logistiek vakman (manager vershandel, logistiek en transport)

25133 - assistent-manager internationale handel

97440 - bloemendetailhandel (manager bloembinden)

25420 - ondernemer vers

25166 - ondernemer retail

90850 - verkoopmanager mobiliteitsbranche

97790 - gezelschapsdierenbranche (ondernemer gezelschapsdieren)

25438 - vakexpert agrohandel en logistiek

25137 - vestigingsmanager groothandel

25240 - verkoopmanager mobiliteitsbranche

97690 - in- en verkoop vershandel (in- en verkoper vershandel)

25218 - aftersalesmanager mobiliteitsbranche

92820 - juweliersbedrijf (juwelier)

24122 - Mbo4 - transport en logistiek

0831 - visserij

95737 - visserij officier (stuurman alle vissersschepen s4)

25523 - Stuurman alle vissersschepen S4

1041 - transport en logistiek

91850 - luchtvaartdienstverlener

91870 - manager transport en logistiek

95260 - havenlogistiek (manager havenlogistiek)

95728 - koopvaardij officier alle schepen (maritiem officier alle schepen)

90216 - logistiek supervisor (logistiek supervisorkc handel)

25363 - luchtvaartdienstverlener

25388 - logistiek supervisor

90217 - logistiek supervisor (logistiek supervisor vtl)

95730 - koopvaardij officier alle schepen (stuurman alle schepen)

93010 - aviation operations officer (aviation operations officer)

91860 - luchtvaartlogisticus

95640 - binnenvaart (kapitein binnenvaart)

25379 - manager transport en logistiek

25396 - co $\div$ rdinator havenoperaties

280

220 
25517 - Stuurman alle schepen

95729 - koopvaardij officier alle schepen (scheepswerktuigkundige alle schepen)

97730 - recreatiedieren (ondernemer/manager recreatiedieren)

97713 - productiedieren (melkveehouder)

93810 - mobiele werktuigen (technicus landbouwmechanisatie)

97681 - teelt 4 (manager teelt)

97650 - groen, grond, infra (manager gemechaniseerd loonbedrijf)

25440 - vakexpert teelt en groene technologie

97712 - productiedieren (dierenhouder hokdieren)

25468 - bedrijfsleider paardensport en -houderij

97561 - zorg, natuur en gezondheid (ondernemer zorgbedrijf dier)

25446 - bedrijfsleider dierverzorging

97242 - paardensport (manager paardensportbedrijf)

97640 - biologisch-dynamisch bedrijf (manager biologisch-dynamisch bedrijf)

25534 - Vakexpert teelt en groene technologie

97682 - teelt 4 (specialist teelt en techniek)

97562 - zorg, natuur en gezondheid (ondernemer zorgbedrijf plant)

24212 - Mbo4 - slagerij, bakkerij, versindustrie

0214 - kunstnijverheid

25445 - vakexpert bloem, groen en styling

25442 - bedrijfsleider/ondernemer bloem, groen en styling

0721 - levensmiddelentechnologie

25183 - patissier

97541 - voedingsmanagement (voedingsspecialist)

94242 - brood en banket (leidinggevende bakkerij)

90304 - ondernemer horeca/bakkerij (ondernemer bakkerij)

97542 - voedingsmanagement (manager voeding)

25464 - vakexpert voeding en voorlichting

94241 - brood en banket (patissier)

97520 - kwaliteitsmanagement voeding (kwaliteitsco@rdinator)

25463 - vakexpert voeding en technologie

25462 - vakexpert voeding en kwaliteit

94770 - leidinggevende versindustrie (productieleider versindustrie)

24213 - Mbo4 - tuinbouw en groenvoorziening

0812 - tuinbouw

97090 - natuur en groene ruimte 4 (manager natuur en recreatie)

25454 - opzichter/uitvoerder groene ruimte

243 - Mbo4 - techniek en ict

2431 - Mbo4 - ict, media en vormgevin

24311 - Mbo4 - ict- en mediabeheer

0612 - ontwerp en beheer van database en netwerken

95321 - ict- en mediabeheer (ict-beheerder)

95323 - ict- en mediabeheer (netwerkbeheerder)

25190 - netwerk- en mediabeheerder

25189 - ict-beheerder

95322 - ict- en mediabeheer (mediaworkflowbeheerder)

0211 - audiovisuele techniek en mediaproductie

40420

95702 - av-productie (av-specialist goc)

90411 - mediavormgever (animatie/audiovisuele vormgeving goc)

90414 - mediavormgever (interactieve vormgeving kc goc)

93220 - game artist

95313 - applicatie- en mediaontwikkeling (mediadeveloper)

90403 - mediavormgever (grafische vormgeving savantis)

90412 - mediavormgever (art \& design kc goc)

25187 - applicatie- en mediaontwikkelaar

95715 - podium- en evenemententechniek (podium- en evenemententechnicus licht)

95714 - podium- en evenemententechniek (podium- en evenemententechnicus geluid)

95312 - applicatie- en mediaontwikkeling (gamedeveloper)

90075 - av-productie (fotograaf kc goc)

90401 - mediavormgever (animatie/audiovisuele vormgeving savantis)

94990 - signmaker (signspecialist)

90083 - av-productie (fotograaf vapro)

95701 - applicatie- en mediaontwikkeling (mediadeveloper)

25205 - podium- en evenemententechnicus licht

25188 - gamedeveloper

95716 - podium- en evenemententechniek (podium- en evenemententechnicus podium \& rigging)

90404 - mediavormgever (interactieve vormgeving savantis)

95703 - av-productie (av-specialist kenniscentrum pmlf) 
95700 - applicatie- en mediaontwikkeling (gamedeveloper)

25204 - podium- en evenemententechnicus geluid

90076 - av-productie (fotograaf savantis)

90402 - mediavormgever (art \& design savantis)

25215 - signspecialist

0212 - mode-, interieur- en industriële vormgeving

90940 - interieuradviseur

91541 - vormgeving ruimtelijke presentatie en communicatie (stand-, winkel- en decorvormgever )

91542 - vormgeving ruimtelijke presentatie en communicatie (vormgever productpresentatie)

97490 - natuur en vormgeving (specialist natuur en vormgeving)

94524 - middenkaderfunctionaris afbouw en onderhoud (kleur- en interieuradviseur

91543 - vormgeving ruimtelijke presentatie en communicatie (winkelpubliciteitvormgever)

94790 - human technology

25212 - ruimtelijk vormgever

25265 - technicus human technology

2432 - Mbo4 - techniek, bouw en procesindustrie

24321 - Mbo4 - bouw en infra

0731 - architectuur en stedebouwkunde

25106 - middenkaderfunctionaris landmeetkunde

94053 - middenkaderfunctionaris bouw en infra (middenkaderfunctionaris landmeetkunde)

0732 - bouwkunde en civiele techniek

94051 - middenkaderfunctionaris bouw en infra (middenkaderfunctionaris bouw)

94052 - middenkaderfunctionaris bouw en infra (middenkaderfunctionaris infra)

93873 - kaderfunctionaris bouw, infra en gespecialiseerde aannemerij (kaderfunctionaris uitvoering bouw en infra)

92741 - specialist schilderen (specialist decoratie en restauratie)

25119 - uitvoerder bouw/infra

94525 - middenkaderfunctionaris afbouw en onderhoud (projectleider)

94523 - middenkaderfunctionaris afbouw en onderhoud (ondernemer)

94521 - middenkaderfunctionaris afbouw en onderhoud (calculator/onderhoudsspecialist)

25014 - uitvoerder

95734 - maritiem waterbouwer (scheepswerktuigkundige waterbouw)

94054 - middenkaderfunctionaris bouw en infra (middenkaderfunctionaris verkeer en stedenbouw)

25107 - middenkaderfunctionaris restauratie

95735 - maritiem waterbouwer (stuurman waterbouw)

93020 - baggermeester

92742 - specialist schilderen (specialist interieur en decoratie)

93872 - kaderfunctionaris bouw, infra en gespecialiseerde aannemerij (kaderfunctionaris uitvoering)

24322 - Mbo4 - elektro- en installatietechniek

0710 - techniek en technische dienstverlening

94421 - middenkader engineering (technicus)

94422 - middenkader engineering (commercieel technicus)

92512 - werkvoorbereiden (werkvoorbereider fabricage)

25297 - technicus engineering

25122 - werkvoorbereider fabricage

0713 - elektro- en energietechniek

94331 - service apparatuur en installaties (servicetechnicus elektrotechniek)

92410 - elektrotechnische industri+le producten en systemen (technicus)

94291 - installeren (leidinggevend monteur elektrotechnische installaties)

25276 - technicus elektrotechniek

94333 - service apparatuur en installaties (servicetechnicus installatietechniek)

25263 - technicus elektrotechnische installaties woning en utiliteit

94292 - installeren (leidinggevend monteur werktuigkundige installaties)

25343 - technicus elektrotechnische systemen

92132 - infratechniek (technicus gas/warmte kenteq)

25311 - technicus service en onderhoud werktuigkundige installaties

25277 - technicus gas

92131 - infratechniek (technicus data/elektra kenteq)

94332 - service apparatuur en installaties (servicetechnicus koudetechniek)

25313 - tekenaar ontwerper elektrotechniek

25262 - technicus elektrotechnische industriùle installaties en systemen

25309 - technicus service en onderhoud elektrotechniek en instrumentatie

24323 - Mbo4 - procestechniek en textiel

0711 - scheikundige technologie en procestechniek

90240 - hoofdoperator

93716 - analist (technisch onderwijs assistent (toa))

25303 - operator $c$

0723 - textiel-, kleding-, schoenen-, en leervervaardiging

95740 - medewerker mode/maatkleding (specialist mode/maatkleding )

94471 - medewerker design (medewerker styling)

93781 - productieco@rdinator fashion (commercieel medewerker fashion)

25526 - Junior stylist

93685 - creatief vakmanschap (lederwarenmaker)

93683 - creatief vakmanschap (ambachtelijk schoenmaker)

93684 - creatief vakmanschap (hoedenmaker)

25164 - specialist mode/maatkleding

24324 - Mbo4 - werktuigbouwkunde en metaalbewerking

0715 - werktuigbouwkunde en metaalbewerking 
91680 - operationele techniek (allround operationeel technicus)

94262 - machinebouw mechatronica (mechatronicus)

94261 - machinebouw mechatronica (allround machinebouwer)

94360 - fijnmechanische techniek (researchinstrumentmaker)

92513 - werkvoorbereiden (werkvoorbereider installatie)

94334 - service apparatuur en installaties (servicetechnicus werktuigbouw)

25344 - technicus mechatronica systemen

25507 - Verspaningstechnoloog

92803 - goud- en zilversmeden (goudsmid)

25310 - technicus service en onderhoud werktuigbouw

25314 - tekenaar ontwerper werktuigkundige installaties

25312 - tekenaar constructeur

25124 - werkvoorbereider installaties

95210 - uurwerktechniek (uurwerktechnicus)

92804 - goud- en zilversmeden (zilversmid)

92511 - werkvoorbereiden (tekenaar constructeur)

92514 - werkvoorbereiden (tekenaar werkvoorbereider)

0716 - voertuigtechniek, scheepsbouw- en vliegtuigbouwkunde

93430 - autotechniek (technisch specialist personenauto's)

95764 - vliegtuigonderhoud (technicus mechanica)

95763 - vliegtuigonderhoud (technicus avionica)

93460 - bedrijfsautotechniek (technisch specialist bedrijfsauto's)

93080 - scheeps- en jachtbouwkundige

94251 - bedrijfsmanagement mobiliteitsbranche (bedrijfsmanager mobiliteitsbranche innovam)

93384 - werkplaatsmanagement mobiliteitsbranche (werkplaatsmanager motorvoertuigentechniek)

25249 - technisch specialist personenauto's

25374 - scheeps- en jachtbouwkundige

25247 - technicus mobiele werktuigen

25248 - technisch specialist bedrijfsauto's

95722 - technisch specialist verbrandingsmotoren

0722 - houtbewerking, papier-, kunsttofverwerking, keramiek

94592 - meubelmaker/(scheeps)interieurbouwer (ondernemer meubelindustrie/(scheeps)interieurbouw)

93686 - creatief vakmanschap (ontwerpend meubelmaker)

94651 - werkvoorbereider houtbranche (werkvoorbereider meubelindustrie/(scheeps)interieurbouw )

94591 - meubelmaker/(scheeps)interieurbouwer (meewerkend leidinggevende meubelindustrie/(scheeps)interieurbouw)

93681 - creatief vakmanschap (glazenier)

93682 - creatief vakmanschap (keramist)

94652 - werkvoorbereider houtbranche (werkvoorbereider timmerindustrie)

25020 - werkvoorbereider meubelindustrie/(scheeps)interieurbouw

94630 - montagemedewerker timmerindustrie (meewerkend leidinggevende montage timmerindustrie)

25009 - werkvoorbereider industrieel produceren met hout

244 - Mbo4 - zorg en dienstverlening

2441 - Mbo4 - dienstverlenin

24411 - Mbo4 - facilitaire dienstverlenin

1011 - huishoudkunde, facilitiare dienstverlening en reiniging

95750 - facilitaire dienstverlener (facilitair leidinggevende)

25175 - facilitair leidinggevende

24412 - Mbo4 - horeca

1013 - horeca

90303 - ondernemer horeca/bakkerij (manager/ondernemer horeca)

25184 - manager/ondernemer horeca

94161 - medewerker bediening/caf+-bar (leidinggevende bediening)

90301 - ondernemer horeca/bakkerij (manager/ondernemer cafe-bar)

95102 - kok (leidinggevende keuken)

25179 - gespecialiseerd kok

25177 - manager/bedrijfsleider fastservice

95101 - kok (gespecialiseerd kok)

25170 - leidinggevende bediening

95432 - fastservice (manager/ bedrijfsleider fastservice)

25181 - leidinggevende keuken

25169 - gastronoom/sommelier

25185 - meewerkend horeca ondernemer

90302 - ondernemer horeca/bakkerij (manager/ondernemer fastservice)

24413 - Mbo4 - schoonheids- en haarverzorging

1012 - schoonheids- en haarverzorging

95745 - schoonheidsspecialist (allround schoonheidsspecialist)

95742 - kapper (ondernemend kapper)

25401 - salonmanager

25403 - allround schoonheidsspecialist

25402 - allround grimeur

91210 - allround grimeur

95743 - pedicure (medisch pedicure)

24414 - Mbo4 - sport en bewegen

1014 - sport

95294 - sport en bewegen (sport- en bewegingsco@rdinator/trainer/coach)

95292 - sport en bewegen (sport- en bewegingsco@rdinator/ bos-medewerker)

95293 - sport en bewegen (sport- en bewegingsco@rdinator/ operationeel sport- en bewegingsmanager)

240

130

90

90

80

40

40

30

30

20

10

0

0
910

430
170

60

60

50 
TYPE (POA publicatie indeling)

ISCEDF2013

Centraal Register Code

91310 - doktersassistent

25473 - doktersassistent

25480 - mbo-verpleegkundige

0916 - farmacie

91300 - apothekersassistent

25471 - apothekersassistent

249 - Mbo4 - overig

2499-Mbo4 - overig

24999 - Mbo4 - overig

0521 - milieu

97372 - milieu en ruimte (milieufunctionaris aequor)

25459 - milieu-onderzoeker

97371 - milieu en ruimte (toezichthouder milieu en ruimte)

25458 - milieu-inspecteur

31 - Hbo-, wo-bachelor

311 - Bachelor - economie en maatschappij

3111 - Bachelor - dienstverlening

31111 - Bachelor - horeca, vrije tijd en faciliteitsmanagement

1011 - huishoudkunde, facilitiare dienstverlening en reiniging 34500 - b facility management

80004 - ad facility management

1013 - horeca

34411 - b hoger hotelonderwijs || b hotel management

80041 - ad hoger hotelonderwijs || ad hotel management

1014 - sport

34040 - b sport en bewegen || b sports and physical exercise

34059 - b sport en bewegingseducatie || b sports and physical education

34057 - b sport, gezondheid en management || b sports, health and management

80026 - ad operationeel sportmanagement || ad sport, health and management

1015 - toerisme en vrijetijdsbesteding

34410 - $b$ hoger toeristisch en recreatief onderwijs || b tourism management

34952 - b media en entertainment management || b media \& entertainment management

30003 - b leisure management

39271 - b functiegerichte bachelor in toerisme en recreatie || b profession-oriented tourism and recreation

80009 - ad functiegerichte bachelor in toerisme en recreatie || ad profession-oriented tourism and recreation

55001 - $b$ tourism (joint degree)

80040 - ad vrijetijdsmanagement || ad leisure management

80088 - ad facilitair eventmanagement || ad event management

30110 - b vitaliteitsmanagement \& toerisme || b vitality \& tourism management

80031 - ad eventmanager || ad event manager

50756 - b vrijetijdwetenschappen || b international leisure sciences

80082 - ad vitaliteitsmanagement \& toerisme || ad vitality \& tourism management

80072 - ad hoger toeristisch en recreatief onderwijs || ad tourism management

31112 - Bachelor - transport en logistiek

1041 - transport en logistiek

34436 - b logistiek en economie || b logistics management (economics)

34390 - $b$ logistiek en technische vervoerskunde || b logistics management (engineering)

34384 - b maritiem officier || b maritime officer

39225 - b aviation

80115 - ad logistiek en economie || ad logistics management (economics)

3112 - Bachelor - economie en recht

31121 - Bachelor - economie en econometrie

0311 - economie en econometrie

56833 - b econometrie en operationele research || b econometrics and operations research

59316 - $b$ international studies

56402 - b fiscale economie || b fiscal economics

56401 - b economie || b economics

50101 - $b$ economie en beleid || $b$ economics and governance

31122 - Bachelor - financieel management en fiscaal recht

0411 - financieel management en fiscaal recht

34406 - b accountancy

56827 - b fiscaal recht || b tax law

34140 - b fiscaal recht en economie

80008 - ad accountancy

0412 - financiële dienstverlening

34414 - b financial services management || b hoger onderwijs financi+le en zakelijke dienstverlening

80038 - ad financi+le dienstverlening || ad financial services management

0416 - groothandel en detailhandel

34422 - b small business \& retail management

39203 - b vastgoed en makelaardij || b real estate management

80010 - ad small business en retail management || ad small business \& retail management

34041 - b trade management gericht op azi+ | | b trade management for asia

81000 - b small business and retail management || b small business \& retail management

30024 - b greenport business \& retail

80103 - ad commerci+le economie || ad marketing

80126 - ad sales en accountmanagement

31123 - Bachelor - management, bedrijfs- en personeelwetenschappen

1.040 
0410 - bedrijfskunde en administratie

56836 - $b$ bedrijfs- en consumentenwetenschappen || b management and consumer studies 130

0413 - management bedrijfs-en personeelswetenschappen 17.200

34401 - $b$ bedrijfseconomie || b finance and control 2.010

34139 - $b$ bedrijfskunde mer || b business management studies 1.750

34609 - b personeel en arbeid || b human resource management 1.590

34936 - $b$ international business and management studies 1.570

50950 - b economie en bedrijfseconomie || b economics and business || b economics and business economics 1.390

50645 - $b$ bedrijfskunde || b business administration 1.050

34421 - b technische bedrijfskunde || b industrial engineering \& management 980

50019 - $b$ international business 830

50952 - b international business administration 810

34407 - $b$ international business and languages 580

50905 - b economie en bedrijfskunde || b economics and business administration 480

56994 - $b$ technische bedrijfskunde || b industrial engineering \& management science 350

56627 - $b$ bestuurskunde || b public administration science 310

34866 - $b$ bedrijfskunde en agribusiness || $b$ agribusiness and business administration 300

34419 - b european studies || b hogere europese beroepen opleiding || b european studies 290

50750 - b bedrijfseconomie || b business economics 240

50007 - b bestuurs- en organisatiewetenschap || b public administration and organisation science 220

34464 - $b$ bestuurskunde/overheidsmanagement || b public administration 210

34145 - $b$ business studies 200

56995 - b technische bestuurskunde || b systems engineering, policy analysis \& management 170

34951 - $b$ kunst en economie II b art and economics 160

50627 - $b$ internationale organisaties en internationale betrekkingen || b international relations and international organization 150

34538 - $b$ management in de zorg || b health care management 140

80011 - ad management in de zorg || ad health care management 120

34106 - $b$ bedrijfsmanagement mkb || b business management sme 120

30029 - $b$ international business 110

34125 - b people and business management 110

30016 - b advanced business creation 100

50754 - b organisatiewetenschappen 100

80074 - ad bedrijfskunde || ad business administration 100

80073 - ad human resource management 80

34432 - b food \& business 70

80080 - ad ondernemen || ad entrepreneurship 70

34130 - $b$ business management 60

56869 - b informatie, multimedia en management 60

56654 - b european public administration 60

50755 - b personeelwetenschappen 50

80065 - ad bedrijfseconomie || ad finance and control 50

34138 - $b$ toegepaste bedrijfskunde || b applied business administration 40

80020 - ad technische bedrijfskunde || ad business engineering: management engineering || ad industrial engineering \& management 30

30017 - $b$ windesheim honours college 30

80028 - ad bedrijfskunde en agribusiness || ad management en beleid buitenruimte || ad agribusiness and business administration 30

39281 - b international food \& agribusiness 30

30035 - $b$ international business innovation studies 10

30034 - $b$ international fresh business management 10

56461 - b juridische wetenschappen I| b recht en bestuur 0

31124 - Bachelor - marketing en public relations 3.490

0414 - marketing en public relations 3.490

34402 - b commerci+le economie || b marketing 3.090

80007 - ad officemanagement 190

34126 - b commercieel management || b commercial management 150

80036 - ad marketing management 50

80096 - ad commercieel management || ad commercial management 20

31125 - Bachelor - recht 5.040

0421 - recht 5.040

50700 - b rechtsgeleerdheid || b law 2.940

39205 - b hbo - rechten || b laws 1.510

50017 - b european law school 280

56828 - b notarieel recht || b notarial law 120

56829 - b internationaal en europees recht || b international and european law 80

56475 - b global law 60

34121 - $b$ hogere juridische opleiding || b laws
50620 - b recht en ict

$\begin{array}{ll}50620 \text { - b recht en ict } & 0023 \text { - ad integrale handhaving omgevingsrecht || ad environmental law enforcement } 0\end{array}$

3113 - Bachelor - journalistiek, gedrag en maatschappij 11.880

31131 - Bachelor - communicatie en journalistiek 3.670

0321 - journalistiek 3.640

34405 - b communicatie || b communication 1.870

34105 - b media, informatie en communicatie || b media, information \& communication 470

34686 - b journalistiek || b journalism 360

56826 - b communicatie- en informatiewetenschappen 310

56615 - b communicatiewetenschap || b communication science 310

170

50374 - b international bachelor's programme in communication and media 140 
50016 - b toegepaste communicatiewetenschap || b applied communication science

80139 - ad communicatie

0322 - bibliotheek, documentaire informatievoorziening

34649 - b informatiedienstverlening en -management || b information services \& management

50010 - b documentaire informatiewetenschap || b culturele informatiewetenschap || b cultural information studies

31132 - Bachelor - psychologie, sociale en maatschappijwetenschappen

0312 - politicologie en maatschappijwetenschappen

56606 - b politicologie || b political science

0313 - psychologie

56604 - b psychologie || b psychology

34507 - b toegepaste psychologie || b applied psychology

34644 - b creatieve therapie || b arts therapies

34585 - b psychomotorische therapie en bewegingsagogie || b psychomotoric therapy/psychomotricity

39206 - b muziektherapie || b music therapy

0314 - sociologie en culturele wetenschappen

50393 - $b$ liberal arts and sciences

55002 - $b$ liberal arts and sciences || $b$ liberal arts and sciences (joint degree)

56051 - b europese studies || b european studies

56838 - b sociale geografie en planologie || b human geography and urban and regional planning

56469 - b criminologie

50035 - b culturele antropologie en ontwikkelingssociologie || b cultural anthropology and development sociology

56601 - b sociologie || b sociology

50906 - b media en cultuur || b media and culture

56631 - b algemene sociale wetenschappen || b interdisciplinary social sciences

50429 - b liberal arts and sciences: global challenges

56823 - b algemene cultuurwetenschappen || b cultural studies

59312 - b politics, psychology, law and economics

50004 - b cultuurwetenschappen

56837 - $b$ internationale ontwikkelingsstudies || b international development studies

50623 - b american studies

56839 - b milieu-maatschappijwetenschappen || b environmental social sciences

50427 - $b$ technology and liberal arts \& sciences

30041 - b popular culture

3114 - Bachelor - kunst, taal en cultuur

31141 - Bachelor - kunst

0210 - kunst

30099 - b interdisciplinary arts

0211 - audiovisuele techniek en mediaproductie

34092 - b communication and multimedia design || b communication \& multimedia design

34430 - b communicatiesystemen || b communication systems

39279 - b game architecture and design || b game architecture \& design

34713 - b kunst en techniek (cognitief ergonomisch ontwerpen/interaction design) || b kunst en techniek

30036 - $b$ creative media and game technologies

34733 - b film en televisie || b film and television

34060 - b grafimediatechnologie || b mediatechnologie || b grafimediatechnology || b media technology

0212 - mode-, interieur- en industriële vormgeving

34389 - $b$ industrieel produkt ontwerpen || $b$ industrial design engineering

56955 - $b$ industrieel ontwerpen || $b$ industrial design

39240 - b engineering, design and innovation || b engineering, design \& innovation

39200 - b lifestyle

50441 - $b$ industrial design

56265 - $b$ techniek en maatschappij || b technische innovatiewetenschappen || b innovation sciences

50447 - b creative technology

34089 - b human technology

80021 - ad interieurvormgever || ad interior design

0213 - beeldende kunst, kunstgeschiedenis

39111 - b vormgeving || b design

39110 - $b$ autonome beeldende kunst || b fine art

39109 - b beeldende kunst en vormgeving | | b art \& design

56824 - $b$ kunstgeschiedenis || b art history

50629 - b kunsten, cultuur en media

80078 - ad arts \& crafts

55822 - b media, kunst, design en architectuur

0215 - muziek en theater

34739 - b muziek || b music

34798 - $b$ dans || b dance

34860 - $b$ theater || b theatre

56700 - b muziekwetenschap || b musicology

56702 - b theaterwetenschap || b theatre studies

34128 - b circus arts

30014 - b circus and performance art

80085 - ad dans

80027 - ad muziek (dirigent hafabra) || ad music

31142 - Bachelor - taal en cultuu

0221 - theologie, levensbeschouwing

35146 - $b$ godsdienst-pastoraal werk || b theology

55004 - b theologie (joint degree) 
56105 - $b$ humanistiek

56109 - b theologie

50902 - b religiestudies || b religious studies

30007 - b imam/islamitisch geestelijk werker

56120 - b islamitische theologie || b islamstudies || b islamic studies

0222 - geschiedenis, archeologie

$56034-b$ geschiedenis || b history

34735 - b museologie || b cultureel erfgoed || b cultural heritage

56703 - $b$ archeologie

39208 - b archeologie || b archeologisch onderzoeksassistent

56825 - b archeologie en prehistorie || b archaeology and prehistory

56704 - b oudheidkunde

0223 - filosofie en ethiek

56081 - b wijsbegeerte || b philosophy

57084 - b wijsbegeerte van een bepaald wetenschapsgebied

0231 - vreemde talen

56806 - $b$ engelse taal en cultuur || b english language and culture

56124 - b europese talen en culturen

34456 - b ori+ntaalse talen en communicatie || b oriental languages \& communication

56805 - b duitse taal en cultuur || b german language and culture

50290 - $b$ english language and culture

56818 - $b$ talen en culturen van china

56808 - $b$ franse taal en cultuur | $b$ french language and culture

56003 - $b$ griekse en latijnse taal en cultuur || b greek and latin language and culture

56819 - $b$ talen en culturen van japan

56098 - $b$ midden-oostenstudies

34098 - $b$ vertaalacademie || $b$ translation and interpreting

56052 - $b$ talen en culturen van latijns amerika/spaans

56810 - b spaanse taal en cultuur || b spanish language and culture

56074 - $b$ romaanse talen en culturen

56820 - $b$ talen en culturen van korea

56809 - b italiaanse taal en cultuur || b italian language and culture

56813 - b slavische talen en culturen || b slavonic language and culture

50855 - $b$ russische studies

56040 - $b$ arabische taal en cultuur || $b$ arabic language and culture

56012 - b friese taal en cultuur

56091 - $b$ keltische talen en cultuur

80030 - ad schrijftolk || ad speech to text interpreter

56807 - b scandinavische talen en culturen || b scandinavian languages and cultures

56041 - b islam en arabisch

56123 - b oude culturen van de mediterrane wereld

56821 - $b$ talen en culturen van afrika || $b$ afrikaanse talen en culturen

56816 - b latijnse taal en cultuur

50901 - b hebreeuwse taal en cultuur || b hebrew language and culture

56099 - b zuid- en zuidoost-azi+studies || b south and south east asian studies

56814 - b nieuwgriekse taal en cultuur

50201 - b hebreeuwse en joodse studies || b hebreeuwse en aramese talen en culturen

0232 - moedertaal, literatuur-, taalwetenschap

56804 - b nederlandse taal en cultuur || b dutch language and culture

56803 - $b$ taalwetenschap || b general linguistics

56801 - $b$ taal- en cultuurstudies

56802 - b literatuurwetenschap

50414 - b film- en literatuurwetenschap

55823 - b literatuur en samenleving

312 - Bachelor - landbouw en natuur

3121 - Bachelor - landbouw, wiskunde en natuurwetenschappen

31211 - Bachelor - landbouw, biologie en biochemische technologie

0511 - biologie

56860 - b biologie || b biology

55009 - b molecular science and technology (joint degree)

50014 - b psychobiologie || b psychobiology

30009 - b toegepaste biologie || b applied biology

55003 - b nanobiologie (joint degree) | | b nanobiology (joint degree)

39217 - $b$ biometrie || b biometrics

0512 - biochemie

56990 - $\mathrm{b}$ biomedische wetenschappen || b biomedical sciences

56226 - $b$ biomedische technologie || b biomedical engineering

55010 - b life science and technology (joint degree)

56286 - b life science and technology

56868 - $b$ voeding en gezondheid || $b$ nutrition and health

34122 - $b$ food design and innovation

34112 - $b$ forensisch onderzoek || b forensic science

39215 - b bio-informatica || b bio-informatics

59304 - b moleculaire levenswetenschappen || b molecular life sciences

50800 - b medische natuurwetenschappen || b medical natural sciences

56944 - b molecular life sciences

0521 - milieu 
50425 - $b$ future planet studies

34284 - b milieukunde II b environment

56968 - $b$ bodem, water en atmosfeer || b soil, water, atmosphere

50100 - $b$ internationaal land- en waterbeheer || b international land and water management

56283 - b milieuwetenschappen || b milieukunde || b environmental sciences

56988 - b milieu-natuurwetenschappen || b environmental sciences

0811 - landbouw en veeteelt

34869 - b dier- en veehouderij || b animal husbandry

34333 - b diermanagement || b animal management

34868 - $b$ tuinbouw en akkerbouw || b horticulture and arable farming

56849 - b dierwetenschappen || b animal sciences

34226 - $b$ land- en watermanagement || $b$ land and water management

56835 - b plantenwetenschappen || b plant sciences

34203 - $b$ tropische landbouw || b agri systems management

80044 - ad melkveehouderij || ad dairy farm management

56831 - b agrotechnologie || b agricultural and bioresource engineering || b biosystems engineering

80128 - ad land- en watermanagement

80006 - ad dier-en veehouderij || ad animal husbandry

80012 - ad tuinbouw en akkerbouw || ad horticulture and arable farming

80070 - ad duurzaam bodembeheer

0821 - bosbouw

34221 - $b$ bos- en natuurbeheer || $b$ forestry and nature management

56219 - $b$ bos- en natuurbeheer || $b$ forest and nature conservation

31212 - Bachelor - wis-, schei-, natuurkunde en geologie

0500 - wiskunde, natuurwetenschappen

30008 - $b$ applied science

56982 - b algemene natuurwetenschappen || b natuurwetenschap en innovatiemanagement

50670 - b science, business \& innovation

56948 - b science

0531 - scheikunde

56857 - b scheikunde || b chemistry

55012 - b scheikunde (joint degree)

56943 - b chemistry

0532 - aardwetenschappen

56986 - b aardwetenschappen || b earth sciences

50668 - $b$ aarde en economie

30033 - b geo media \& design

0533 - natuurkunde

56962 - $b$ technische natuurkunde || b applied physics

56984 - $b$ natuur- en sterrenkunde || b physics and astronomy

34268 - $b$ technische natuurkunde || $b$ engineering physics

50206 - b natuurkunde I| b physics

55013 - b natuur- en sterrenkunde (joint degree)

50205 - b sterrenkunde || b astronomy

0541 - wiskunde

56980 - b wiskunde || b mathematics

56965 - $b$ technische wiskunde || $b$ industrial and applied mathematics

35168 - $b$ wiskunde || b bedrijfswiskunde || b mathematics and applications

56856 - $b$ bedrijfswiskunde en informatica || b business mathematics and informatics

0542 - statistiek

56411 - b actuari+le wetenschappen || b actuarial science

313 - Bachelor - techniek en ict

3131 - Bachelor - techniek en ict

31311 - Bachelor - bouwkunde, civiele techniek en architectuur

0731 - architectuur en stedebouwkunde

56951 - b bouwkunde || b architecture, urbanism \& building sciences

39280 - $b$ built environment

34220 - $b$ tuin- en landschapsinrichting || b garden and landscape architecture

30038 - b ruimtelijke ontwikkeling

56947 - b geografie, planologie en milieu || b geography, spatial planning and environment

34859 - b plattelandsvernieuwing || b rural innovation

56848 - b landschapsarchitectuur en ruimtelijke planning || b landscape, architecture and planning

56194 - $b$ technische planologie

34282 - b ruimtelijke ordening en planologie || b urban and regional planning

39204 - b kust en zee management || b coastal zone management

34190 - b hydrografie || b ocean technology || b hydrographic surveyor

30028 - $b$ landscape and environment management

34272 - $b$ geodesie || b geodesy/geo-informatics

39278 - $b$ delta management

80068 - ad tuin- en landschapsinrichting

34133 - b stedenbouwkundig ontwerpen || b urban design

0732 - bouwkunde en civiele techniek

34263 - $b$ bouwkunde || $b$ architecture and construction engineering

34279 - b civiele techniek || b civil engineering

56952 - $b$ civiele techniek || b civil engineering

34261 - $b$ bouwtechnische bedrijfskunde || $b$ construction management

34074 - b watermanagement || b water management

120

100

40

40

10

820

280

130

110

70

60 
34371 - $b$ verkeerskunde || $\mathrm{b}$ mobiliteit || $\mathrm{b}$ traffic and transport management || $\mathrm{b}$ traffic engineering

39232 - b bouwmanagement en vastgoed || b building process management \& real estate

80121 - ad integraal bouwmanagement

80016 - ad civiele techniek projectuitvoering en -realisatie || ad civiele techniek projectvoorbereiding en -realisatie

80034 - ad bouwkunde II ad architecture and construction engineering

80042 - ad civiele techniek directievoering

80125 - ad bouwtechnisch medewerker

31312 - Bachelor - chemische technologie

0711 - scheikundige technologie en procestechniek

34396 - b chemie || b chemistry

34275 - $b$ chemische technologie || $b$ chemical engineering

56960 - b scheikundige technologie || b chemical engineering

56841 - b biotechnologie || b biotechnology

34331 - b biotechnologie || b biotechnology

80005 - ad chemische technologie || ad chemical engineering

0712 - milieubescherming en milieutechnologie

34332 - b aquatische ecotechnologie || b water management

30102 - b climate \& environment

80069 - ad duurzame watertechnologie

0721 - levensmiddelentechnologie

34856 - $b$ voedingsmiddelentechnologie || b food technology

56973 - b levensmiddelentechnologie || b food technology

30022 - b food commerce \& technology

0723 - textiel-, kleding-, schoenen-, en leervervaardiging

34254 - $b$ technische commercitle confectiekunde || b fashion and technology

34255 - $\mathrm{b}$ technische commerci+le textielkunde || $\mathrm{b}$ textile engineering and management || b textiles and fashion

30037 - b fashion \& textile technologies

0724 - delfstofwinning

56959 - $\mathrm{b}$ technische aardwetenschappen || b applied earth sciences

31313 - Bachelor - elektrotechniek

0713 - elektro- en energietechniek

34267 - b elektrotechniek || b electrical and electronic engineering

56953 - b elektrotechniek || b electrical engineering

80039 - ad installatietechniek || ad installation technology || ad projectleider techniek || ad projectleader engineering

34369 - b energie- en procestechnologie (aot) | | b energy and processtechnology (aot)

80123 - ad elektrotechniek/energietechniek

0714 - elektronica en industriële automatisering

56964 - b technische informatica || b computer science \& engineering

30026 - b mechatronica || b mechatronics || b mechatronic engineering

34475 - $b$ technische informatica || b computer science

50426 - b computer science

34131 - $b$ embedded systems engineering

30015 - $b$ advanced sensor applications

39216 - $\mathrm{b}$ industri+le automatisering || b industrial automation

80124 - ad elektrotechniek/embedded systems engineering

31314 - Bachelor - informatica

0612 - ontwerp en beheer van database en netwerken

80083 - ad ict service management

30010 - $b$ information security management

80071 - ad ict-beheer || ad ict-service management

80024 - ad it service management

0613 - softwareontwikkeling en systeemanalyse

30020 - b hbo-ict

34479 - b informatica || b information technology

39118 - $b$ business it \& management

56978 - b informatica || b computing science

56842 - b informatiekunde || b information science

50300 - b informatica/kennistechnologie || b informatica/kennistechnologie/ict || b kennistechnologie || b knowledge engineering

56573 - b medische informatiekunde || b medical informatics

56066 - b bedrijfsinformatietechnologie || b business information technology

80132 - ad ict

80130 - ad software development

0619 - informatica overig

56981 - b kunstmatige intelligentie || b artificial intelligence

56945 - $b$ artificial intelligence

56983 - b lifestyle informatics

31315 - Bachelor - werktuigbouwkunde

0710 - techniek en technische dienstverlening

30107 - b engineering

80091 - ad engineering

50002 - $b$ technische wetenschappen || b advanced technology

80079 - ad maintenance \& mechanics

0715 - werktuigbouwkunde en metaalbewerking

34280 - b werktuigbouwkunde || b mechanical engineering

56966 - b werktuigbouwkunde || b mechanical engineering

80076 - ad constructeur werktuigbouwkunde

80019 - ad werktuigbouwkunde || ad mechanical engineering 
0716 - voertuigtechniek, scheepsbouw- en vliegtuigbouwkunde

56956 - b luchtvaart- en ruimtevaarttechniek || b aerospace engineering

30018 - b automotive

56957 - b maritieme techniek || b marine technology

34278 - b luchtvaarttechnologie || b aeronautical engineering

34276 - b scheepsbouwkunde || b naval architecture

80077 - ad systeemspecialist automotive

80067 - ad maritieme techniek || ad marine technology

314 - Bachelor - zorg en onderwijs

3141 - Bachelor - gezondheidszorg en welzijn

31411 - Bachelor - maatschappelijk werk

0923 - maatschappelijk werk en beroepskeuzewerk

34616 - b maatschappelijk werk en dienstverlening || b social work and social services

34116 - b social work

34641 - b sociaal-juridische dienstverlening || b social legal services

34610 - b culturele en maatschappelijke vorming || b cultural and social development

80120 - ad ad sociaal werk in de zorg

80140

80090 - ad sociaal financitle dienstverlening || ad social financial services

31412 - Bachelor - medische diagnostiek en medische technologie

0841 - diergeneeskunde en -verzorging

56570 - b diergeneeskunde || b veterinary medicine

0910 - gezondheidszorg

56553 - b gezondheidswetenschappen

50509 - $b$ gezondheid en leven

50296 - b european public health

50018 - b gezondheid en maatschappij || b health and society || b public health and society

0911 - tandheelkunde

56560 - $b$ tandheelkunde || b dentistry

34576 - b opleiding mondhygiene || b mondzorgkunde || b dental hygiene

0912 - geneeskunde

56551 - b geneeskunde || b medicine

0914 - medische diagnostiek en medische technologie

34397 - b biologie en medisch laboratoriumonderzoek || b biology \& medical laboratory research

34561 - $b$ medisch beeldvormende en radiotherapeutische technieken || b medical imaging and radiation therapy

730

730
300

230

80

70

50
10

(j5007 - b kinische technologie(joint degree) || b clinical technology (joint degree)

34549 - b optometrie || b optometry

34584 - b bewegingstechnologie || b human kinetic technology

50033 - b klinische technologie || b clinical technology

34953 - b orthopedische technologie || b orthoptics technology || b orthopaedic engineering

30039 - $b$ mens en techniek

39219 - $b$ gezondheidszorg technologie || b health care technology

0916 - farmacie

56157 - b farmacie

50207 - b bio-farmaceutische wetenschappen

34090 - b farmakunde || b pharmaceutical business administration

56989 - b farmaceutische wetenschappen || b pharmaceutical sciences

0917 - traditionele en alternatieve geneeskunde en therapie

34506 - b kunstzinnige therapie || b antroposofische gezondheidszorg || b arts therapies

4.100

4.100

1.800

1.180

720

280

70

10
5.980

5.980
170

170

660

380

130

90

0921 - gehandicaptenzorg voor volwassenen en bejaarden- en gezinszorg

34617 - b sociaal pedagogische hulpverlening || b social educational care || b social work 80086 - ad ervaringsdeskundige in de zorg || ad expert by experience in health \& welfare

0922 - jeugdpedagogisch werk en kinderverzorging

80081 - ad pedagogisch educatief medewerker || ad pedagogical educational assistant

30012 - b pedagogisch management kinderopvang || b educational management childcare

31414 - Bachelor - therapie en revalidatie

0915 - therapie en revalidatie

34570 - b opleiding tot fysiotherapeut || b physiotherapy

34579 - $b$ voeding en di+tetiek || b nutrition and dietetics

34578 - b opleiding voor logopedie || b speech and language therapy

34574 - b opleiding voor ergotherapie || b occupational therapy

56950 - $b$ bewegingswetenschappen || $b$ human movement studies

34091 - b huidtherapie || b skin therapy

34572 - b opleiding tot oefentherapeut-mensendieck || b mensendieck kinetics therapy

34581 - b opleiding podotherapie || b podiatry

30109 - b toegepaste gerontologie || b applied gerontology

34571 - b oefentherapie cesar || b cesar kinetics therapy

34577 - b orthoptie || b orthoptics

31415 - Bachelor - verpleeg- en verloskunde

0913 - verpleeg-en verloskunde

34560 - b opleiding tot verpleegkundige || b nursing

34134 - b verloskunde || b midwifery

30023 - b medische hulpverlening || b allied medical care 
35025 - b opleiding tot leraar voortgezet onderwijs van de eerste graad in lichamelijke oefening || b teacher education in physi 35198 - b opleiding tot leraar voortgezet onderwijs van de tweede graad in nederlands || b teacher education in dutch 35195 - b opleiding tot leraar voortgezet onderwijs van de tweede graad in engels || b teacher education in english

35221 - b opleiding tot leraar voortgezet onderwijs van de tweede graad in wiskunde || b teacher education in mathematics 39100 - $b$ docent beeldende kunst en vormgeving || b fine art and design in education

35388 - b opleiding tot leraar voortgezet onderwijs van de tweede graad in gezondheidszorg en welzijn || $\mathrm{b}$ teacher education in 35197 - b opleiding tot leraar voortgezet onderwijs van de tweede graad in geschiedenis || b teacher education in history 35421 - b opleiding tot leraar voortgezet onderwijs van de tweede graad in omgangskunde || b teacher education in social skills 35203 - b opleiding tot leraar voortgezet onderwijs van de tweede graad in bedrijfseconomie || b teacher education in finance an 35202 - b opleiding tot leraar voortgezet onderwijs van de tweede graad in algemene economie || b teacher education in general $e$ 35301 - b opleiding tot leraar voortgezet onderwijs van de tweede graad in biologie || b teacher education in biology 35201 - b opleiding tot leraar voortgezet onderwijs van de tweede graad in aardrijkskunde || b teacher education in geography 34745 - $b$ docent drama || b docent theater || b theatre in education

35193 - b opleiding tot leraar voortgezet onderwijs van de tweede graad in duits || b teacher education in german

35210 - $b$ opleiding tot leraar voortgezet onderwijs van de tweede graad in het technisch beroepsonderwijs 39112 - b docent muziek || b music in education

34899 - b educatie en kennismanagement groene sector | | b education and knowledge management in the land based sector

35261 - b opleiding tot leraar voortgezet onderwijs van de tweede graad in natuurkunde || b teacher education in physics

35411 - b opleiding tot leraar voortgezet onderwijs van de tweede graad in maatschappijleer || b teacher education in social stu 34940 - $b$ docent dans || b dance in education

35196 - b opleiding tot leraar voortgezet onderwijs van de tweede graad in frans || b teacher education in french

35204 - b opleiding tot leraar voortgezet onderwijs van de tweede graad in pedagogiek || b teacher education in educational theo

35423 - b opleiding tot leraar voortgezet onderwijs van de tweede graad in consumptieve techniek i en ii || b teacher education

35199 - b opleiding tot leraar voortgezet onderwijs van de tweede graad in scheikunde || b teacher education in chemics

35207 - b opleiding tot leraar voortgezet onderwijs van de tweede graad in economie

34104 - b opleiding tot leraar nederlandse gebarentaal (ngt) / bacheloropleiding tot tolk ngt || b teacher sign language of the

35255 - b opleiding tot leraar voortgezet onderwijs van de tweede graad in spaans || b teacher education in spanish

80045 - ad onderwijsondersteuner gezondheidszorg en welzijn

35441 - b opleiding tot leraar voortgezet onderwijs van de tweede graad in godsdienst || b teacher education in religion

35254 - b opleiding tot leraar voortgezet onderwijs van de tweede graad in techniek || b teacher education in technology

80098 - ad onderwijsondersteuner technisch beroepsonderwijs

35208 - b opleiding tot leraar voortgezet onderwijs van de tweede graad in mens en technologie || b teacher education in technol 80052 - ad onderwijsondersteuner consumptieve techniek i en ii

35205 - b opleiding tot leraar voortgezet onderwijs van de tweede graad in islamgodsdienst || b teacher education in islamic stu 80060 - ad onderwijsondersteuner omgangskunde || ad social and personal competences

80015 - ad educatie en kennismanagement groene sector bloemsierkunst || ad floristry

80064 - ad onderwijsondersteuner educatie en kennismanagement groene sector

80051 - ad onderwijsondersteuner techniek || ad technology education

35144 - b opleiding tot leraar voortgezet onderwijs van de tweede graad in fries || b teacher education in frisian

31422 - Bachelor - lerarenopleiding basisonderwijs, speciaal onderwijs en basiseducatie

0113 - lerarenopleiding basisonderwijs, speciaal onderwijs en basiseducatie

34808 - b opleiding tot leraar basisonderwijs || b education in primary schools (age 4 - 12)

35514 - b international teacher education for primary schools (iteps)

31423 - Bachelor - onderwijskunde

0111 - onderwijskunde

35158 - b pedagogiek || b educational theory

56607 - b pedagogische wetenschappen || b pedagogical sciences

56613 - b onderwijskunde || b educational sciences

39218 - b opleidingskunde || b education science

80127 - ad pedagogisch professional kind en educatie

319 - Bachelor - overig

3199 - Bachelor - overig

31999 - Bachelor - overig

1032 - openbare orde en veiligheid

39201 - b integrale veiligheid || b applied safety \& security studies

39268 - b integrale veiligheidskunde || b applied safety \& security studies

30105 - b security management

9999 - onbekend of niet gespecifieerd

50250 - b beta-gamma || b natural and social sciences

32 - Hbo-, wo-master, doctor

321 - Master - economie en maatschappij

3211 - Master - economie en recht

32111 - Master - economie en econometrie

0311 - economie en econometrie

66401 - m economics

60734 - $\mathrm{m}$ internationale betrekkingen || $\mathrm{m}$ international relations

60079 - $m$ econometrics and management science

66402 - $\mathrm{m}$ fiscale economie || $\mathrm{m}$ fiscal economics

60177 - m econometrics

66833 - $m$ econometrics and operations research

60646 - $m$ econometrics, operations research and actuarial studies

60057 - m operations research and management sciences

60389 - $\mathrm{m}$ economics and social sciences || m economics of public policy and management

60464 - $\mathrm{m}$ human decision science

60819 - $\mathrm{m}$ internationale betrekkingen || m international relations

60056 - $\mathrm{m}$ econometrics and mathematical economics || m mathematical economics and econometric methods

60162 - $\mathrm{m}$ philosophy in economics (research) I/ $\mathrm{m}$ tinbergen institute master of philosophy in economics 
60307 - $m$ econometrics and operations research

60444 - $m$ spatial, transport and environmental economics

60388 - $m$ economics and law || m economics of competition and regulation

60125 - $\mathrm{m}$ operations research/bedrijfswiskunde

60018 - $m$ infonomics || m information and network economics

$60909-\mathrm{m}$ master of philosophy in economics (research)

60012 - $\mathrm{m}$ economic and financial research (research)

60820 - $\mathrm{m}$ internationale betrekkingen (research) I| m international relations (research)

60907 - $\mathrm{m}$ multidisciplinary economics (research)

32112 - Master - financieel management en fiscaal recht

0411 - financieel management en fiscaal recht

66827 - $m$ fiscaal recht || $m$ tax law

$60900-m$ accountancy and control

60060 - $m$ accountancy || m accountancy and management contro

69313 - $m$ accounting, auditing and control

$60047-m$ accounting and control

$60643-m$ accountancy and controlling

60683 - $m$ international financial management

60459 - $m$ international and european tax law

60686 - $m$ international business taxation

0412 - financiële dienstverlening

60046 - $m$ finance

60409 - $m$ finance \& investments

60321 - $m$ financial economics

60449 - $m$ aansprakelijkheid en verzekering

0416 - groothandel en detailhandel

60659 - $m$ vastgoedkunde

32113 - Master - management, bedrijfs- en personeelwetenschappen

0410 - bedrijfskunde en administratie

66836 - m management, economics and consumer studies

0413 - management bedrijfs- en personeelswetenschappen

60644 - $m$ business administration

60652 - $m$ economics and business

60019 - $m$ international business

60066 - $m$ strategic management

60020 - $m$ public administration

44135 - $m$ leren en innoveren I| m education for professional learning and development

60648 - $m$ international economics and business

66627 - $\mathrm{m}$ bestuurskunde || $\mathrm{m}$ public administration

60446 - $m$ bestuurs- en organisatiewetenschap

60052 - $m$ beleid, communicatie en organisatie

60081 - m zorgmanagement

60082 - $m$ health economics, policy and law

60328 - $m$ public policy and human development

66430 - $\mathrm{m}$ operations management || m operations management and logistics

65006 - m entrepreneurship (joint degree)

60075 - $m$ human resource studies

60649 - $m$ international business and management

60754 - $m$ organisation studies

60458 - m management of innovation

60460 - $m$ healthcare policy, innovation and management

60645 - $m$ human resource management

$60803-m$ management, policy analysis and entrepreneurship in the health and life sciences

60456 - m global business \& stakeholder management

60407 - m international management

66995 - $m$ management of technology

60050 - m cultuur, organisatie en management || m culture, organization and management

60358 - $m$ systems engineering, policy analysis and management

66277 - $m$ technology management || m technology and operations management

60416 - $m$ management van de publieke sector

60256 - $\mathrm{m}$ international business administration || m international management

44136 - $m$ learning \& innovation

60430 - $m$ innovation management

60448 - $m$ international public management and public policy

60901 - $m$ business economics

60455 - m entrepreneurship \& new business venturing

60457 - m organisational change \& consulting

60001 - m organisational learning || m management of learning

60179 - $m$ engineering and policy analysis

60003 - $m$ european public affairs

60315 - $\mathrm{m}$ economics and business: production, organization and marketing (research)

40120 - $\mathrm{m}$ digitale innovatie in zorg en welzijn

49124 - m crossover creativity

65008 - $m$ business in society

60391 - $m$ research in public administration and organizational science (research)

66265 - $m$ technology and policy || $m$ innovation sciences

49132 - $m$ innovatie in zorg en welzijn 
66461 - $m$ juridische bestuurswetenschappen || $m$ recht en bestuur

60013 - $m$ business research (research)

69320 - $m$ science, business and innovation

49122 - $\mathrm{m}$ marine shipping innovations

1041 - transport en logistiek

60093 - m supply chain management

60361 - $m$ transport, infrastructure and logistics

60445 - $\mathrm{m}$ global supply chain management and change

32114 - Master - marketing en public relations

0414 - marketing en public relations

60063 - m marketing management

60048 - $m$ marketing

60064 - $m$ marketing research

32115 - Master - recht

0421 - recht

60084 - $m$ rechtsgeleerdheid

66451 - m nederlands recht

60224 - $m$ international and european law

60219 - m privaatrecht II m private law

66828 - $m$ notarieel recht

60408 - $m$ ondernemingsrecht

60170 - $\mathrm{m}$ globalisation and law

60220 - $\mathrm{m}$ publiekrecht I| m public law

60452 - m commercial law

60072 - $m$ international business law || $m$ international european business law

60222 - $\mathrm{m}$ arbeidsrecht || m labour law

60741 - $m$ recht en onderneming

60069 - $m$ law and technology

60418 - $\mathrm{m}$ forensische criminologie

60856 - $m$ public international law

60171 - $\mathrm{m}$ forensica, criminologie en rechtspleging || $\mathrm{m}$ forensics, criminology and law

60017 - m european law school

60086 - $m$ financieel recht

66474 - $m$ jeugdrecht

60223 - $m$ informatierecht || m information law

60685 - $m$ law and politics of international security

60451 - $m$ recht van de gezondheidszorg

60169 - $m$ recht en arbeid II $m$ recht, arbeid en gezondheid

60419 - $m$ criminaliteit en rechtshandhaving

60742 - $\mathrm{m}$ law and economics || m juridische-economische studies

60605 - $m$ international law and the law of international organization

66829 - $m$ internationaal en europees recht

60602 - m european law

60620 - $m$ recht en ict

60450 - $m$ togamaster

60412 - $m$ european private law

60168 - m international laws || m law and language studies

60744 - $m$ rechtswetenschappelijk onderzoek (research) || m legal research (research)

66456 - $m$ international criminal law

60606 - $m$ functionaliteit van het recht (research) || m rechtswetenschap en onderzoek (research)

60604 - $m$ international economic and business law

60603 - $m$ international and comparative private law

60393 - $\mathrm{m}$ grondslagen en methoden van de rechtswetenschap (research)

60366 - $m$ information law (research)

60386 - $\mathrm{m}$ onderneming en recht (research)

60369 - m public international law (research)

3212 - Master - journalistiek, gedrag en maatschappi

32121 - Master - communicatie en journalistiek

0321 - journalistiek

66615 - m communicatiewetenschap || m communication science

66826 - m communicatie- \& informatiewetenschappen || m communication \& information studies

60713 - $m$ communication studies

66652 - $m$ applied communication science

60833 - m communicatie- \& informatiewetenschappen || m communication \& information studies

60030 - $m$ human media interaction

60163 - $m$ communication science (research)

60653 - m mens-machine communicatie || m human-machine communication

60834 - m communicatie- \& informatiewetenschappen (research) || m communication \& information studies (research)

32122 - Master - psychologie

0313 - psychologie

66604 - $m$ psychology

60260 - m psychologie

60216 - $\mathrm{m}$ gezondheidszorg psychologie || $\mathrm{m}$ healthcare psychology

60383 - m psychology (research)

66581 - m medische psychologie

60077 - $\mathrm{m}$ sociale psychologie || m social psychology

60266 - $m$ behavioural science: the study of behaviour regulation (research) 
60510 - m cognitive neuropsychology (research)

69305 - $m$ forensic psychology

60053 - m social psychology: regulation of social behaviour (research)

60513 - m clinical and developmental psychopathology (research)

49108 - $m$ danstherapie II $m$ dance therapy

60954 - $m$ individual differences and assessment (research)

49286 - $m$ master of music therapy

32123 - Master - sociale en maatschappijwetenschappen

0312 - politicologie en maatschappijwetenschappen

66606 - $\mathrm{m}$ politicologie $\mid \mathrm{I}$ m political science

60203 - $m$ political science

69314 - $m$ conflict resolution and governance

60070 - $m$ sociaal recht en sociale politiek

60421 - $\mathrm{m}$ political science and public administration (research)

0314 - sociologie en culturele wetenschappen

60830 - m mediastudies || m media studies

66601 - $m$ sociologie || m sociology

66469 - $m$ criminologie

66620 - m sociale geografie || m human geography

60746 - $m$ algemene sociale wetenschappen

66837 - $m$ international development studies

60329 - $m$ international development studies

60284 - m europese studies || m european studies

69303 - $m$ european studies

60831 - $\mathrm{m}$ mediastudies || m media studies

60466 - $m$ human geography

60731 - $\mathrm{m}$ development studies || m ontwikkelingsgeografie

60745 - $m$ culturele antropologie

60845 - m noord-amerika studies || m north american studies

60156 - $m$ culturalanthropology and development sociology

60465 - $\mathrm{m}$ globalisation and development studies

60847 - $m$ europese studies

66614 - $\mathrm{m}$ culturele antropologie en sociologie der niet-westerse samenlevingen || m cultural and social anthropology

60214 - $m$ social sciences (research)

60832 - $\mathrm{m}$ mediastudies (research) || m media studies (research)

66725 - $\mathrm{m}$ victimology and criminal justice

60732 - m geografie || m geographical sciences

66839 - $\mathrm{m}$ milieu-maatschappijwetenschappen || $\mathrm{m}$ social and political science of the environment

66599 - $m$ sociology

60657 - $m$ economische geografie

60654 - $m$ human behaviour in social contexts (research) II $\mathrm{m}$ behavioural and social sciences (research)

60049 - $m$ social and cultural anthropology

65002 - $m$ europese studies (joint degree) || m european studies (joint degree)

60218 - $m$ international development studies (research) II m human geography, planning and development studies (research)

66724 - $m$ international crimes and criminology

60384 - $\mathrm{m}$ methodologie en statistiek van de sociale wetenschappen (research) || m methodology and statistics of behavioral and s

60198 - $\mathrm{m}$ medische antropologie en sociologie || m medical anthropology and sociology

60658 - $m$ population studies

60253 - $\mathrm{m}$ culturele antropologie en ontwikkelingsstudies || m anthropology and development studies

60378 - $m$ cultural anthropology: sociocultural transformation (research)

60166 - $m$ human geography and planning (research)

60394 - $m$ social and behavioural sciences (research)

60669 - $m$ criminal law and criminology

66631 - $\mathrm{m}$ migration, ethnic relations and multiculturalism (research)

60748 - $m$ sociology and social research (research)

60377 - $m$ european studies (research)

60132 - $\mathrm{m}$ social and cultural science: comparative research on societies (research)

60656 - m culturele geografie

60211 - m comparative asian studies || m contemporary asian studies

1015 - toerisme en vrijetijdsbesteding

60111 - $m$ leisure, tourism and environment

60078 - $\mathrm{m}$ leisure studies

49135 - $m$ international leisure and tourism studies

49287 - $m$ tourism destination management

0211 - audiovisuele techniek en mediaproductie

49121 - $\mathrm{m}$ professional master in media innovation

60206 - m mediatechnology

49131 - m digital design

49123 - $m$ animatie

49106 - $m$ type and media

49107 - $m$ media design and communication

44756 - $m$ fotografie II m photography

44758 - $\mathrm{m}$ grafisch ontwerpen || m graphic design

44733 - $m$ film

49101 - m typografie || m typography 
49120 - m game technology

0212 - mode-, interieur- en industriële vormgeving

60029 - $m$ industrial engineering and management

60354 - $m$ integrated product design

60355 - $m$ design for interaction

60356 - $m$ strategic product design

66955 - $m$ industrial design engineering

60441 - $m$ industrial design

60431 - m human-technology interaction

49238 - $m$ interieurarchitectuur || $m$ interior architecture

44760 - $m$ interior architecture \& retail design

49128 - $m$ innovative textile development

49102 - $m$ fashion

44804 - $\mathrm{m}$ modevormgeving || m fashion strategy

49097 - $m$ applied nanotechnology

0213 - beeldende kunst, kunstgeschiedenis

60087 - m kunst- \& cultuurwetenschappen || m arts \& culture

60829 - m kunst- \& cultuurwetenschappen (research) || m arts \& culture (research)

44853 - $m$ autonome beeldende kunst || $m$ fine art

49284 - mperforming public space

49098 - $m$ master design

60828 - m kunst- \& cultuurwetenschappen || m arts \& culture

44749 - $m$ vrije vormgeving || $\mathrm{m}$ applied arts

0215 - muziek en theater

44739 - m muziek || m music

49114 - $\mathrm{m}$ mfa theatervormgeving/beeldregie || m scenography

44852 - $m$ master of music

44874 - $m$ theater

49104 - $\mathrm{m}$ sonologie || $\mathrm{m}$ sonology

49125 - $m$ theatre practices

49105 - m opera

40118 - $\mathrm{m}$ theater

49103 - m choreografie || m choreography

32132 - Master - taal en cultuur

0221 - theologie, levensbeschouwing

60824 - $m$ theologie \& religiewetenschappen || m theology \& religious studies

66105 - m humanistiek

66122 - $m$ gemeentepredikant

60257 - $m$ theologie || $m$ theology

60827 - $m$ theologie \& religiewetenschappen (research) II m theology \& religious studies (research)

66117 - $m$ theologie algemeen

60264 - $m$ verdieping

60261 - $m$ predikantschap

60825 - m theologie \& religiewetenschappen || m theology \& religious studies

0222 - geschiedenis, archeologie

$66034-\mathrm{m}$ geschiedenis || m history

60805 - $\mathrm{m}$ archeologie

60139 - m geschiedenis (research) || m history (research)

60821 - $m$ oudheidstudies || m classics \& ancient civilizations

60835 - $\mathrm{m}$ erfgoed studies || m heritage studies

60133 - $\mathrm{m}$ archeologie (research) || m archaeology (research)

60335 - $m$ conservering en restauratie van cultureel erfgoed

60039 - m oudheidstudies (research) || m classics \& ancient civilizations (research)

60808 - $m$ erfgoedstudies

60836 - $\mathrm{m}$ erfgoed studies || $\mathrm{m}$ heritage studies

0223 - filosofie en ethiek

60822 - $m$ filosofie II m philosophy

60823 - m filosofie || m philosophy

60128 - m filosofie (research) II m philosophy (research)

60504 - m european law || m international and european law (socrates)

60711 - $m$ geschiedenis en wijsbegeerte van de wiskunde en natuurwetenschappen

60953 - $m$ zorgethiek en beleid

60908 - $m$ master of philosophy in business (research)

60024 - $m$ philosophy of science, technology and society

60313 - $m$ erim master of philosophy in business research (research)

69321 - $\mathrm{m}$ philosophy, politics and economics

0231 - vreemde talen

60839 - $\mathrm{m}$ azi+ studies || $\mathrm{m}$ asian studies

60842 - $\mathrm{m}$ midden-oosten studies || m middel eastern studies

60174 - m latijns-amerika studies || m latin american studies

60840 - $\mathrm{m}$ azi+ studies || $\mathrm{m}$ asian studies

60848 - $m$ russische en euraziatische studies || $m$ russian and eurasian studies

60843 - m midden-oosten studies (research) || m middle eastern studies (research)

60841 - $\mathrm{m}$ azi+ studies (research) || m asian studies (research)

60838 - $m$ afrika studies (research) || $m$ african studies (research)

60844 - m latijns-amerika studies (research) || m latin american studies (research)

60837 - $\mathrm{m}$ afrika studies || m african studies 
0232 - moedertaal, literatuur-, taalwetenschap 60815 - $m$ taalwetenschappen I| m linguistics 60813 - $\mathrm{m}$ letterkunde I| m literary studies

60817 - $m$ taalwetenschappen (research) || m linguistics (research)

$60849-\mathrm{m}$ neerlandistiek || $\mathrm{m}$ dutch studies

60814 - $m$ letterkunde (research) II m literary studies (research)

60740 - $m$ talenonderwijs en communicatie

60850 - $m$ neerlandistiek || m dutch studies

60816 - $m$ taalwetenschappen || m linguistics

60851 - m neerlandistiek (research) II m dutch studies (research)

322 - Master - landbouw en natuur

3221 - Master - landbouw, wiskunde en natuurwetenschappen

32211 - Master - landbouw, biologie en biochemische technologie

0511 - biologie

66860 - $m$ biology

60293 - $m$ biologische wetenschappen

60806 - $m$ neurosciences

60704 - $m$ neuroscience and cognition || m neurowetenschappen en cognitie

60707 - $\mathrm{m}$ biological sciences

60616 - $\mathrm{m}$ biomolecular sciences

60609 - $\mathrm{m}$ mariene biologie || m marine biology

65011 - m nanobiology (joint degree)

60225 - $m$ life sciences

60956 - $\mathrm{m}$ systems biology

0512 - biochemie

66990 - $m$ biomedical sciences

66226 - $m$ biomedical engineering

66286 - $m$ life science and technology

60121 - $\mathrm{m}$ cognitive and clinical neuroscience (research) || m biopsychology and psychopathology (research) || m cognitive neuros

60610 - $\mathrm{m}$ medische biologie || m medical biology

60112 - $m$ food safety

60303 - $\mathrm{m}$ molecular life sciences || m molecular health sciences

60506 - $m$ cognitive neurosciences (research)

60462 - $\mathrm{m}$ biology of human performance and health

60106 - $m$ bio-informatics

60338 - $\mathrm{m}$ forensic science

60322 - $m$ molecular mechanisms of disease (research)

60109 - $m$ food quality management

60615 - $m$ behavioural and cognitive neurosciences (research)

60278 - $m$ neuroscience (research)

60800 - $\mathrm{m}$ medical natural sciences

60279 - $\mathrm{m}$ molecular medicine (research)

66586 - $\mathrm{m}$ cardiovascular research (research)

0521 - milieu

60810 - $m$ environmental sciences

65003 - $m$ industrial ecology (joint degree)

60045 - m environment and resource management

60104 - $m$ international land- and water management

60110 - m urban environmental management

60107 - $\mathrm{m}$ climate studies || m earth system science

60365 - $m$ ecology and evolution

60607 - $m$ ecology

0811 - landbouw en veeteelt

66849 - $\mathrm{m}$ animal sciences and aquaculture || $\mathrm{m}$ animal sciences

66835 - $\mathrm{m}$ plant sciences

60100 - $\mathrm{m}$ soil science II m earth and environment

69300 - m organic agriculture

0821 - bosbouw

66219 - $m$ forest and nature conservation

0831 - visserij

$60804-\mathrm{m}$ aquaculture and fisheries || $\mathrm{m}$ aquaculture and marine resource management

32212 - Master - wis-, schei-, natuurkunde en geologie

0500 - wiskunde, natuurwetenschappen

60709 - $\mathrm{m}$ science and innovation management || $\mathrm{m}$ natuurwetenschappen en innovatiemanagement || $\mathrm{m}$ natuurwetenschappen en bestuur 60710 - $m$ natuurwetenschappen en bedrijf

66982 - $\mathrm{m}$ algemene natuurwetenschappen || m natuurwetenschappen (research)

0531 - scheikunde

65012 - $m$ chemistry (joint degree)

66857 - $m$ chemistry

60706 - $\mathrm{m}$ chemische wetenschappen

0532 - aardwetenschappen

66986 - $m$ earth sciences

60360 - $\mathrm{m}$ applied earth sciences

60108 - $m$ geo-information science

0533 - natuurkunde

60439 - $m$ mechanical engineering

60436 - $\mathrm{m}$ applied physics 
65016 - $m$ physics and astronomy (joint degree)

140

60202 - $m$ physics

60705 - $m$ natuurkunde en meteorologie \& fysische oceanografie

60200 - m astronomy

66984 - $m$ natuur- en sterrenkunde

60028 - $m$ nanotechnology

66904 - $\mathrm{m}$ science and technology of nuclear fusion

60618 - $m$ nanoscience

$60230-\mathrm{m}$ astronomy and astrophysics

60232 - $m$ mathematical physics

0541 - wiskunde

66980 - $m$ mathematics

60348 - $m$ applied mathematics

66856 - $m$ business mathematics and informatics

60703 - $m$ mathematische wetenschappen

60226 - $m$ logic

$60957-\mathrm{m}$ master statistical science for the life and behavioural sciences

60801 - $m$ stochastics and financial mathematics

0542 - statistiek

66411 - $\mathrm{m}$ actuarial science and mathematical finance || $\mathrm{m}$ actuari+le wetenschappen

60058 - $m$ quantitative finance and actuarial sciences

323 - Master - techniek en ict

3231 - Master - techniek en ict

32311 - Master - bouwkunde, civiele techniek en architectuur

0731 - architectuur en stedebouwkunde

60349 - $\mathrm{m}$ architecture || $\mathrm{m}$ architecture, urbanism and building sciences

60434 - $m$ architecture, building and planning

66622 - $\mathrm{m}$ planologie || $\mathrm{m}$ urban and regional planning

66194 - $\mathrm{m}$ technische planologie || m environmental and infrastructure planning

44336 - $m$ architectuur || $m$ architecture

66848 - $m$ landscape, planning \& design || $m$ landscape, architecture and planning

66653 - $\mathrm{m}$ sociale planologie || m socio-spatial plannning

66954 - m geodetic engineering || m geomatics

60103 - $\mathrm{m}$ development and rural innovation II m management of agro-ecological knowledge and social change

60217 - $m$ metropolitan studies (research)

44337 - $m$ landschapsarchitectuur || $m$ landscape architecture

44338 - $m$ stedebouw || m urbanism

$60660-m$ regional studies:spaces and places, analysis and intervention (research)

49503 - $m$ master of urban and area development (joint degree)

0732 - bouwkunde en civiele techniek

60352 - $m$ civil engineering

60337 - $m$ construction management and engineering

60026 - $m$ civil engineering and management

60807 - $m$ hydrology

32312 - Master - chemische technologie

0711 - scheikundige technologie en procestechniek

60437 - $m$ chemical engineering

66841 - $m$ biotechnology

65005 - $m$ water technology (joint degree)

60105 - $\mathrm{m}$ plant biotechnology

66831 - $m$ agricultural and bioresource engineering

60612 - $\mathrm{m}$ moleculaire biologie en biotechnologie II m molecular biology and biotechnology

60955 - $\mathrm{m}$ biobased materials

0712 - milieubescherming en milieutechnologie

69315 - $m$ sustainability science and policy

69319 - m environmental and energy management

0721 - levensmiddelentechnologie

66973 - $m$ food technology

60512 - $m$ health food innovation management

0724 - delfstofwinning

60178 - $\mathrm{m}$ offshore engineering || $\mathrm{m}$ offshore and dredging engineering

32313 - Master - elektrotechniek

0713 - elektro- en energietechniek

60353 - m electrical engineering

60443 - m sustainable energy technology

69299 - $m$ european master in renewable energy

69298 - m european master in sustainable energy system management

60608 - $m$ energie en milieuwetenschappen || m energy and environmental sciences

0714 - elektronica en industriële automatisering

60300 - $m$ computer science

60331 - $m$ embedded systems

60359 - $m$ systems and contro

60438 - $m$ computer science and engineering

65014 - $\mathrm{m}$ computer science (joint degree)

60351 - $m$ computer engineering

49133 - $\mathrm{m}$ control systems engineering

60802 - $\mathrm{m}$ parallel and distributed computer systems 
40015 - $m$ master sensor system engineering

60032 - $m$ telematics

32314 - Master - informatica

0612 - ontwerp en beheer van database en netwerken

60364 - $\mathrm{m}$ computing science

60227 - $\mathrm{m}$ system and network engineering || $\mathrm{m}$ system and network administration

0613 - softwareontwikkeling en systeemanalyse

60453 - $m$ business information management

60229 - $m$ information studies

60055 - $m$ information management

66978 - m informatica

60255 - m information sciences

60228 - $m$ software engineering

60809 - $m$ information science

60347 - $m$ industrial and applied mathematics

65015 - m computational science (joint degree)

$60205-m$ ict in business

60432 - $m$ business information systems

66573 - m medical informatics || m medische informatiekunde

65018 - $m$ data science and entrepreneurship (joint degree)

60025 - $m$ business information technology

60959 - $m$ business intelligence and smart services

60299 - m grid computing

0619 - informatica overig

66981 - $m$ artificial intelligence

60323 - $\mathrm{m}$ brain and cognitive sciences (research) || m cognitive science (research)

32315 - Master - werktuigbouwkunde

0715 - werktuigbouwkunde en metaalbewerking

66958 - $m$ materials science and engineering

0716 - voertuigtechniek, scheepsbouw- en vliegtuigbouwkunde

$66956-\mathrm{m}$ aerospace engineering

66957 - $m$ marine technology

60428 - $m$ automotive technology

49134 - $\mathrm{m}$ master of automotive systems

324 - Master - zorg en onderwijs

3241 - Master - gezondheidszor

32411 - Master - (dier)geneeskunde en tandheelkunde

0841 - diergeneeskunde en -verzorging

66570 - $m$ diergeneeskunde

0911 - tandheelkunde

66588 - $m$ tandheelkunde || m dentistry

0912 - geneeskunde

66551 - $\mathrm{m}$ geneeskunde || $\mathrm{m}$ medicine

49115 - $m$ physician assistant

66585 - $\mathrm{m}$ arts - klinisch onderzoeker

66583 - m geneeskunde, klinisch onderzoeker

60811 - m oncology

60375 - $m$ infection and immunity (research)

60312 - $m$ clinical research (research)

32412 - Master - farmacie en gezondsheidswetenschappen

0910 - gezondheidszorg

66851 - $\mathrm{m}$ health sciences || $\mathrm{m}$ algemene gezondheidswetenschappen

66902 - $m$ global health

60076 - $m$ psychologie en geestelijke gezondheid

60006 - $m$ mental health

$60461-m$ healt education and promotion

60120 - $m$ health sciences (research)

60380 - $\mathrm{m}$ social health psychology (research) || m psychological health research (research) || m social \& health psychology (res

60379 - m european public health

66903 - $\mathrm{m}$ global health (research)

0913 - verpleeg-en verloskunde

49246 - $m$ advanced nursing practice

66563 - $m$ verplegingswetenschap || $m$ klinische gezondheidswetenschappen

40101 - $m$ health care and social work

0914 - medische diagnostiek en medische technologie

60033 - $m$ technical medicine

60344 - $m$ medical engineering

0915 - therapie en revalidatie

66868 - m nutrition and health

66950 - $\mathrm{m}$ human movement sciences || $\mathrm{m}$ human movement sciences: sport, exercise and health || $\mathrm{m}$ bewegingswetenschappen

60684 - $m$ human movement sciences

60812 - m fundamental and clinical human movement sciences (research) || m human movement sciences: sport, exercise \& health (re

60515 - $m$ vitality and ageing

69312 - m european msc in occupational therapy

49127 - $m$ healthy ageing professional

69317 - m musculoskeletal physiotherapy sciences

0916 - farmacie 
66157 - $m$ farmacie

60207 - $m$ bio-pharmaceutical sciences

60294 - m farmaceutische wetenschappen || m pharmaceutical sciences

66989 - $\mathrm{m}$ pharmaceutical sciences || m drug discovery and safety

60611 - $\mathrm{m}$ medisch farmaceutische wetenschappen || m medical pharmaceutical sciences

60617 - $m$ medical and pharmaceutical drug innovation

0919 - gezondheidszorg overig

60011 - m epidemiology

0922 - jeugdpedagogisch werk en kinderverzorging

40019 - $m$ jeugdzorg

0923 - maatschappelijk werk en beroepskeuzewerk

44116 - $\mathrm{m}$ social work

49500 - $\mathrm{m}$ social work (joint degree)

1014 - sport

60682 - $\mathrm{m}$ sport sciences

49285 - $m$ lichamelijke opvoeding en sportpedagogiek

49130 - m master of sports

\section{2 - Master - onderwijs}

32421 - Master - lerarenopleiding algemene en beroepsgerichte vakken

0114 - lerarenopleiding algemene en beroepsgerichte vakken

68404 - $m$ science education and communication

68529 - m educatieve master geesteswetenschappen

45269 - $m$ leraar nederlands || $m$ teacher education in dutch

49117 - $m$ kunsteducatie || m education in arts

68509 - $\mathrm{m}$ leraar voorbereidend hoger onderwijs in maatschappijleer en maatschappijwetenschappen I| m univeristy teacher training

68512 - $\mathrm{m}$ leraar voorbereidend hoger onderwijs in nederlands || $\mathrm{m}$ university teacher training programme dutch

45262 - $\mathrm{m}$ leraar engels || $\mathrm{m}$ teacher education in english

68504 - $m$ leraar voorbereidend hoger onderwijs in engels || m university teacher training programme english

68502 - $\mathrm{m}$ leraar voorbereidend hoger onderwijs in biologie || m university teacher training programme biology

45263 - $m$ leraar wiskunde || $m$ teacher education in mathematics

68506 - $\mathrm{m}$ leraar voorbereidend hoger onderwijs in geschiedenis en staatsinrichting $\mid \mathrm{m}$ university teacher training programme hi

45275 - $\mathrm{m}$ leraar algemene economie || $\mathrm{m}$ teacher education in general economics

68513 - $\mathrm{m}$ leraar voorbereidend hoger onderwijs in scheikunde || $\mathrm{m}$ university teacher training programme chemistry

45265 - $m$ leraar duits || $m$ teacher education in german

45272 - $m$ leraar natuurkunde ||$m$ teacher education in physics

68501 - $m$ leraar voorbereidend hoger onderwijs in algemene economie || m university teacher training programme economics

68500 - $\mathrm{m}$ leraar voorbereidend hoger onderwijs in aardrijkskunde || m university teacher training programme geography

45264 - $\mathrm{m}$ leraar aardrijkskunde || $\mathrm{m}$ teacher education in geography

45273 - $\mathrm{m}$ leraar scheikunde || $\mathrm{m}$ teacher education in chemistry

49501 - $m$ kunsteducatie (joint degree) || m education in arts (joint degree)

68518 - $\mathrm{m}$ leraar voorbereidend hoger onderwijs in management en organisatie || m university teacher training programme managemen

68511 - $\mathrm{m}$ leraar voorbereidend hoger onderwijs in natuurkunde $\mid \mathrm{m}$ university teacher training programme physics

45267 - $\mathrm{m}$ leraar geschiedenis || $\mathrm{m}$ teacher education in history

60708 - m communicatie en educatie van de natuurwetenschappen

68516 - $\mathrm{m}$ leraar voorbereidend hoger onderwijs in wiskunde II $\mathrm{m}$ university teacher training programme mathematics

68505 - $\mathrm{m}$ leraar voorbereidend hoger onderwijs in filosofie $\mid \mathrm{m}$ university teacher training programme philosophy

45274 - $\mathrm{m}$ leraar godsdienst || $\mathrm{m}$ teacher education in theology and religious studies

60614 - $m$ opleiding tot leraar voortgezet onderwijs van de eerste graad in educatie en communicatie in de wiskunde en natuurwete

68517 - $\mathrm{m}$ leraar voorbereidend hoger onderwijs in frans || m university teacher training programme french

45279 - $\mathrm{m}$ leraar biologie || $\mathrm{m}$ teacher education in biology

68519 - $\mathrm{m}$ leraar voorbereidend hoger onderwijs in griekse en latijnse taal en cultuur || m university teacher training programme

60747 - m mens- en maatschappijonderwijs en communicatie

68503 - $\mathrm{m}$ leraar voorbereidend hoger onderwijs in duits $\mid$ | m university teacher training programme german

45268 - $m$ leraar maatschappijleer || $m$ teacher education in social studies

45266 - $m$ leraar frans || $m$ teacher education in french

45271 - $m$ leraar bedrijfseconomie || $m$ teacher education in finance and control

68507 - $\mathrm{m}$ leraar voorbereidend hoger onderwijs in godsdienst en levensbeschouwing || m university teacher training programme re

68508 - $\mathrm{m}$ leraar voorbereidend hoger onderwijs in kunstgeschiedenis en culturele en kunstzinnige vorming/kunst algemeen || m uni

60632 - $m$ opleiding tot leraar voortgezet onderwijs van de eerste graad in engelse taal en cultuur

60243 - $m$ opleiding tot leraar voortgezet onderwijs van de eerste graad in maatschappijleer

60637 - $\mathrm{m}$ opleiding tot leraar voortgezet onderwijs van de eerste graad in nederlandse taal en cultuu

60636 - $m$ opleiding tot leraar voortgezet onderwijs van de eerste graad in griekse en latijnse taal en cultuur

60204 - $m$ opleiding tot leraar voortgezet onderwijs van de eerste graad in aardrijkskunde

68514 - $\mathrm{m}$ leraar voorbereidend hoger onderwijs in spaans || m university teacher training programme spanish

60701 - $m$ kunstonderwijs en communicatie

60238 - $\mathrm{m}$ opleiding tot leraar voortgezet onderwijs van de eerste graad in filosofie

60651 - $m$ opleiding tot leraar voortgezet onderwijs van de eerste graad in economie en bedrijfswetenschappen

68075 - m opleiding tot leraar voortgezet onderwijs van de eerste graad in godsdienst en levensbeschouwing

44104 - m opleiding dovenstudies/masteropleiding leraar nederlandse gebarentaal || m deafstudies/teacher education in sign lan

60631 - $m$ opleiding tot leraar voortgezet onderwijs van de eerste graad in duitse taal en cultuur

45276 - $m$ leraar fries || $m$ teacher education in frisian

68522 - $\mathrm{m}$ leraar voorbereidend hoger onderwijs in italiaans || m university teacher training programme italian

60633 - $m$ opleiding tot leraar voortgezet onderwijs van de eerste graad in franse taal en cultuur

60635 - $\mathrm{m}$ opleiding tot leraar voortgezet onderwijs van de eerste graad in geschiedenis

68510 - $\mathrm{m}$ leraar voorbereidend hoger onderwijs in muziek

32422 - Master - onderwijskunde en pedagogische wetenschappen

0110 - onderwijskunde, lerarenopleidingen en pedagogisch-didactische cursussen

220

70

30

30

20

20

20

10

10

60 


\section{ONR2019}

NIVEAU

SECTOR

SUBSECTOR (POA publicatie indeling)

TYPE (POA publicatie indeling)

ISCEDF2013

Centraal Register Code

68531 - $\mathrm{m}$ leraar voorbereidend hoger onderwijs in zaakvakken

0111 - onderwijskunde

66607 - $\mathrm{m}$ pedagogische wetenschappen I| m pedagogical science

66613 - $\mathrm{m}$ onderwijskunde || m educational science

44113 - $m$ pedagogiek II m educational theory

60396 - $m$ education and child studies

60420 - $m$ pedagogy and education

60023 - $m$ educational science and technology

60749 - $\mathrm{m}$ educational sciences: learning in interaction (research) || m onderwijskunde (research)

60212 - $m$ educational sciences (research master)

60382 - $\mathrm{m}$ development and socialization in childhood and adolescence (research)

49099 - $m$ talentontwikkeling en diversiteit

49248 - $m$ toetsdeskundige

60159 - m educational sciences: normal and deviant patterns of attachment and self regulated learning (research)

0113 - lerarenopleiding basisonderwijs, speciaal onderwijs en basiseducatie

44103 - $\mathrm{m}$ special educational needs: leraar speciaal onderwijs || $\mathrm{m}$ special educational needs: special education teacher

44102 - $\mathrm{m}$ special educational needs: communicatief gehandicapten || $\mathrm{m}$ special educational needs: education for communication dis

44101 - m special educational needs: auditief gehandicapten || m special educational needs: education for hearing disabled

329 - Master - overig

3299 - Master - overig

32999 - Master - overig

1022 - veiligheid op het werk en ergonomie

60007 - $m$ work and health

1032 - openbare orde en veiligheid

60417 - $m$ crisis and security management 